\title{
CARACTERIZAÇÃO FÍSICA, QUÍMICA, MINERALÓGICA E MORFOLÓGICA DE UMA SEQUÊNCIA DE SOLOS EM LINS/SP
}

\author{
LILIANE IBRAHIM
}

Dissertação apresentada à Escola Superior de Agricultura "Luiz de Queiroz", para obtenção do título de Mestre em Agronomia, Área de Concentração: Solos e Nutrição de Plantas.

PIRACICABA

Estado de São Paulo - Brasil Janeiro - 2002 


\section{CARACTERIZAÇÃO FÍSICA, QUÍMICA, MINERALÓGICA E MORFOLÓGICA DE UMA SEQUÊNCIA DE SOLOS EM LINS/SP}

\section{LILIANE IBRAHIM}

Geólogo

Orientador: Prof. Dr. ADOLPHO JOSÉ MELFI

Dissertação apresentada à Escola Superior de Agricultura "Luiz de Queiroz", para obtenção do título de Mestre em Agronomia, Área de Concentração: Solos e Nutrição de Plantas.

PIRACICABA

Estado de São Paulo - Brasil

Janeiro - 2002 
Dados Internacionais de Catalogação na Publicação (CIP)

DIVISÃO DE BIBLIOTECA E DOCUMENTAÇÃO - ESALQ/USP

\section{Ibrahim, Lilia ne}

Ca racterização física, químic a, minerológica e morfológica de uma sequência de solos em Lins/SP / Liliane Ibra him. - - Pira cicaba, 2002. 86 p. : il.

Dissertação (mestrado) - - Escola Superior de Agricultura Luiz de Queiroz, 2002. Bibliografia.

1. Caracterização do solo 2. Dinâmica dos solos 3. Fertirigação 4. Física do solo 5. Micromorfologia do solo 6. Mineralogia do solo 7. Química do solo I. Título

CDD 631.44

\section{"Permitida a cópia total ou parcial deste documento, desde que citada a fonte - $\mathbf{O}$ autor"}


Dedico à

MARLENE JOÃO IBRAHIM,

Ofereço à

PEDRO, KARIME E MAGRÃO. 


\section{AGRADECIMENTOS}

Ao Prof. Adolpho José Melfi pela orientação e apoio durante a execução deste trabalho.

Ao Departamento de Solos e Nutrição de Plantas, através de seus coordenadores Prof. Dr. Luis Reynaldo F. Alleoni. Prof. Dr. Álvaro P. Costa e Prof. Dr. Francisco Antonio Monteiro, pela oportunidade.

À CAPES, pela bolsa de mestrado.

À SABESP/ Lins, pelo apoio prestado nos trabalhos de campo.

À Profa. Dra. Célia Regina Montes, pelo total apoio e incentivo.

Ao Prof. Adilson Carvalho, pelo auxílio nas etapas de campo.

A todas as pessoas do NUPEGEL, especialmente Clotilde, Paulo e Nei, pela ajuda e apoio fundamentais durante estes 2 anos. Ao Sérgio, pelas conversas, auxílio e paciência. Ao Adriel, Mafra, Márcia, Celso, Sandrinha e Camila pela luta e disponibilidade.

Aos funcionários e técnicos do departamento de Solos e Nutrição de Plantas, Márcia, Flávia, Luiz, Luciano, Bety e Vladimir pela ajuda.

Ao Instituto de Geociências - UNESP/ Rio Claro e Prof. Dr. Antenor Zanardo, pelo uso do Laboratório de Microscopia.

As pesquisadoras Vania Rosolen e Célia Surita, pelo apoio, incentivo e discussões.

À amiga Raiza, pela amizade, companheirismo e fundamental auxílio à execução deste projeto.

À Família Hellmeister, pelo imprescindível apoio e compreensão durante este período, especialmente Sônia, Célia e D.Zilda. 


\section{SUMÁRIO}

Página

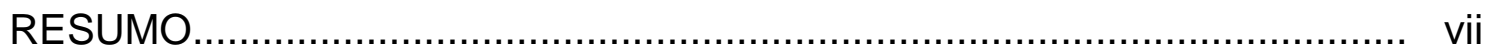

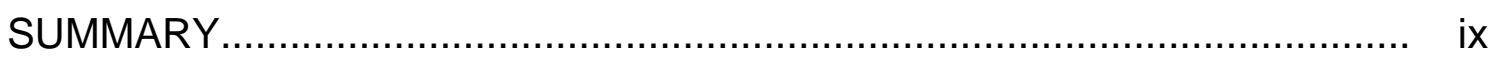

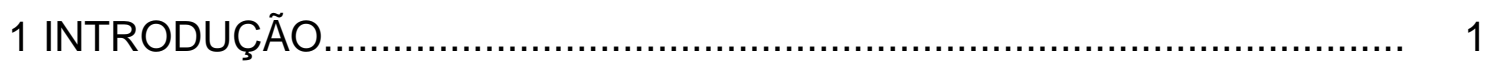

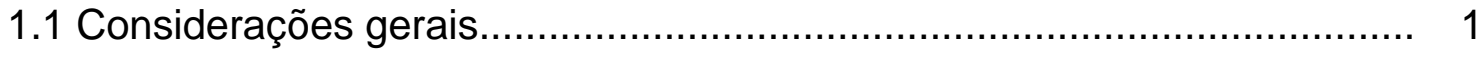

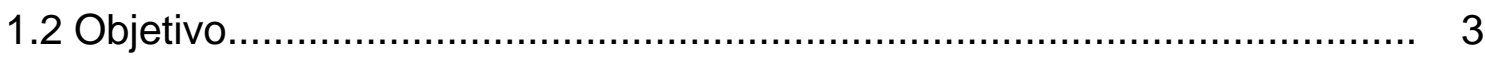

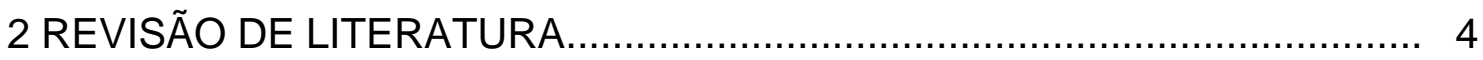

2.1 Distribuição e caracterização da Formação Adamantina........................... 4

2.2 Solos desenvolvidos a partir dos sedimentos do Grupo Baurú................. 7

3 MATERIAL E MÉTODOS.................................................................... 13

3.1 Caracterização do meio físico........................................................ 13

3.2 Escolha das topossequências e locais de amostragem dos solos......... 15

3.2.3 Estudo bidimensional do segmento da vertente................................ 17

3.3 Análises das amostras de solo..................................................... 17

3.3.1 Análise granulométrica............................................................. 17

3.3.2 Análises químicas.................................................................. 17

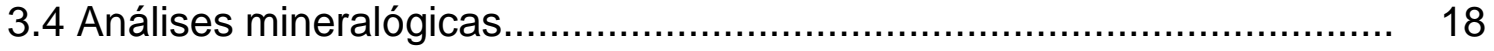

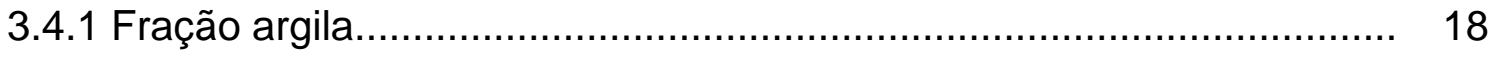

3.4.2 Minerais pesados.................................................................. 18

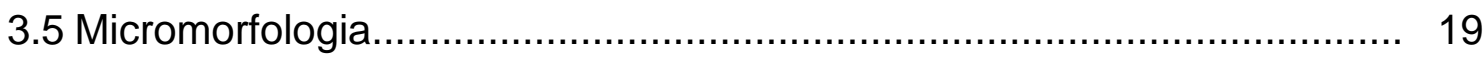

4 RESULTADOS E DISCUSSÃO …...................................................... 20 
4.1 Características morfológicas dos perfis.............................................. 20

4.2 Características granulométricas dos solos ao longo da vertente............. 26

4.3 Caracterização do complexo argilo-húmico dos solos estudados............ 28

4.4 Composição química dos solos estudados........................................... 32

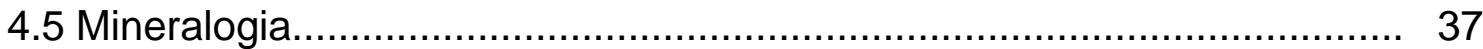

4.5.1 Mineralogia da fração argila....................................................... 37

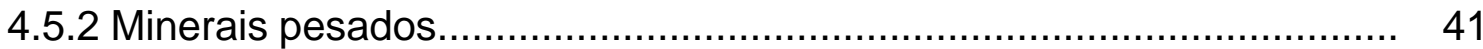

4.6 Características micromorfológicasdos perfis analisados...................... 42

4.6.1 Síntese das características micromorfológicas dos perfis .................. 43

4.6.2 Esquema geral das lâminas analisadas........................................... 55

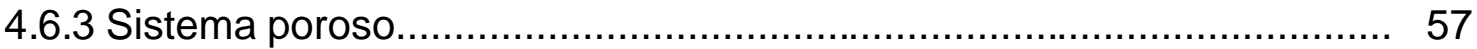

4.7 Considerações gerais sobre a dinâmica dos solos ao longo da vertente.. 59

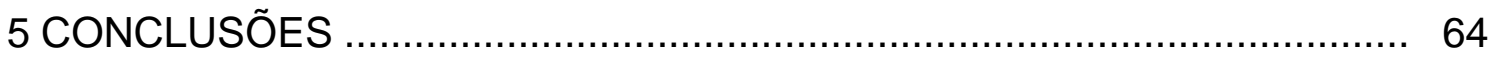

REFERÊNCIAS BIBLIOGRÁFICAS...................................................... 65

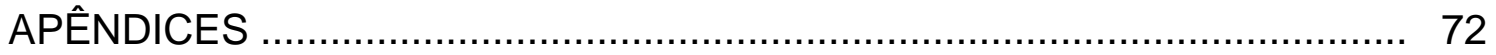




\title{
CARACTERIZAÇÃO FÍSICA, QUÍMICA, MINERALÓGICA E MORFOLÓGICA DE UMA SEQUÊNCIA DE SOLOS EM LINS/SP
}

\author{
Autora: LILIANE IBRAHIM \\ Orientador: Prof. Dr. ADOLPHO JOSÉ MELFI
}

\section{RESUMO}

Este trabalho tem como objetivo a caracterização de um sistema de solos, evidenciando os parâmetros que possam esclarecer sua dinâmica e contribuir para a definição de critérios que possam determinar a aptidão destes solos como receptores de efluentes. Trata-se de uma área experimental de estudos, contígua à Estação de Tratamento de Esgoto do município de Lins $(\mathrm{SP})$, onde efluentes são gerados a partir do tratamento de esgoto por sistema de lagoas de estabilização. Nesta área, vem sendo aplicada a técnica de irrigação com efluentes (fertirrigação). Os solos, situados ao longo de uma vertente com ligeira inclinação, foram caracterizados através de análises morfológicas, granulométricas, químicas, mineralógicas e micromorfológicas, realizadas em amostras coletadas em seis trincheiras abertas ao longo de duas 
topossequências, dispostas segundo o eixo de maior declive da vertente. Os solos são desenvolvidos a partir dos sedimentos arenosos da Formação Adamantina (Grupo Bauru) e constituem um sistema Latossolo - Argissolo, onde a transição $\mathrm{Bw}$ - Bt ocorre lateralmente do topo para a base da vertente. Foram identificadas quatro fases pedogenéticas nesta associação de solos. As duas primeiras, argiluviação e adensamento de partículas, responsáveis pela formação dos horizontes texturais, foram superpostas pelos processos de latossolização e hidromorfismo, atuantes na dinâmica atual destes solos. Análises micromorfológicas mostraram tratar-se de solos com intensa porosidade, caracterizada pelo empilhamento dos grãos do esqueleto quartzoso, amplamente predominante, e pelo arranjo entre os microagregados granulares. A permeabilidade é ainda favorecida pela intensa ação da mesofauna. Os solos são distróficos, com alta saturação por alumínio e compostos por caolinita e óxidos de ferro. Por se constituirem num sistema frágil, a disposição de quaisquer tipos de resíduos nestes solos, requer o monitoramento constante de suas propriedades, tanto para a manutenção, quanto para a recuperação da qualidade desta cobertura pedológica. 


\title{
PHYSICAL, CHEMICAL, MINERALOGICAL AND MORPHOLOGICAL CHARACTERIZATION OF A SOIL SERIES IN LINS/SP.
}

\author{
Author: LILIANE IBRAHIM \\ Adviser: Prof. Dr. ADOLPHO JOSÉ MELFI
}

\section{SUMMARY}

The purpose of this study is to characterize a soil system, identifying the properties which can elucidate its dynamics and to define criterions for the ability of these soils to constitute an effluent disposal land. The experimental area is located nearby the Sewage Treatment Station (STS), in Lins (SP) and the effluent is proceeded for secundary treatment. In this area, is being applied the technique of fertirrigation. The soils are situated on a downslope and were characterized beside morphological, particle size, chemicals, mineralogicals and micromorphologicals analyses on samples collected in six profiles along two toposequences, across the axis of maximun gradient on downslope. These soils are expanded from sandstones of Adamantina Formation (Bauru Group) and compose an Oxisol-Ultisol system. The Bw-Bt transition accurs laterally, from the upper to the lowest part of downslope. It was recognized four pedogenetic phasis. Both first, argilluviation and compressed layer, explain the formation of argillic horizons and were superimposed from latossolization and hydromorphism, both last actuating on the actual dynamics of these soils. 
Micromorphological analysis showed that these soils are too porous, characterized for packing of skeletic grains and between granular aggregates. The permeability is increased by the activity of mesofaunal. These soils are dystrophics, have high aluminium saturation and are composed for kaolinite and iron oxides. This system is fragile, thus, the deposal of any kind of residues on these soils, needs the constant warning of all of their properties, so to the maintenance and also the recover of the quality of this pedologic cover. 


\section{INTRODUÇÃO}

\subsection{Considerações gerais}

O solo, além de desempenhar um papel de fundamental importância para a vida humana, tem sido utilizado cada vez mais em práticas não agrícolas, porém, igualmente importantes para a vida moderna.

Em função de suas qualidades como "filtro biológico", a pedosfera tem se tornado o ecossistema ideal para a disposição de resíduos urbanos, industriais e agrícolas. Entretanto, sua capacidade de depuração não é ilimitada e depende de seus atributos físicos, químicos e mineralógicos.

Portanto, uma boa gestão de resíduos e sua disposição nos solos, depende não só do conhecimento dos resíduos, cujas características físicas, químicas e biológicas podem torná-lo impróprio para sua utilização, como também da caracterização física, química, físico-química e mineralógica do solo onde ele será depositado e com o qual vai interagir.

Atualmente, o uso agrícola de efluentes gerados a partir de sistemas de tratamento por lagoas de estabilização é prática corrente em muitos países, sendo comumente conhecida como fertirrigação ou irrigação de cultivos com águas servidas. Nestes países, a reutilização destes efluentes é regulamentada com legislação específica e faz parte de programas governamentais de irrigação e gestão de recursos hídricos, como é o caso de Israel, Egito, Austrália, Arábia Saudita, Tunísia e Chile (Pescod, 1992). 
Em Israel e Austrália, por exemplo, as pesquisas científicas sobre o tema tem apresentado avanços significativos, havendo resultados conclusivos sobre: razão de perda de nutrientes e outros elementos; lixiviação de metais e compostos orgânicos através de macroporos e como sólidos suspensos; efeito estufa por emissão de gases; fixação á longo prazo de metais e compostos orgânicos na matéria orgânica e constituintes ativos do solo (Cameron et al. 1997).

Entretanto, estes países estão localizados nas zonas temperadas e áridas do planeta, onde os solos apresentam atributos e características totalmente diversas dos solos localizados nas zonas tropicais, impossibilitando a transferência dos resultados ali obtidos para os solos brasileiros.

No Brasil, poucos estudos têm sido desenvolvidos sobre a reciclagem de efluentes. Estes, via de regra, são despejados diretamente na rede de drenagem, poluindo os corpos d'água e contribuindo para a diminuição de água potável para fins domésticos, tendo em vista sua crescente utilização em práticas agrícolas.

Assim sendo, a Companhia de Saneamento Básico do Estado de São Paulo (SABESP), através da Unidade de Negócios do Baixo Tietê e Grande, com sede no município de Lins (SP), que gerencia 195 sistemas de lagoas de estabilização na região noroeste do Estado de São Paulo, em parceria com o Núcleo de Pesquisa em Geoquímica e Geofísica da Litosfera (NUPEGEL) da Universidade de São Paulo (USP), vem desenvolvendo projeto que visa o aproveitamento agrícola dos efluentes originados a partir de sistemas de tratamento por lagoas de estabilização.

O projeto, que envolve pesquisas multidisciplinares, tem como principal objetivo, verificar a viabilidade de uso destes efluentes na agricultura. Ele será desenvolvido em uma área contígua à Estação de Tratamento de Esgoto do município de Lins (SP), onde vários sub-projetos estão sendo conduzidos com o objetivo de determinar a dinâmica da solução do solo, eficiência de sistemas de irrigação e plantio experimental de diferentes culturas. 


\subsection{Objetivos}

Tendo em vista que a aplicação da fertirrigação e seu sucesso dependem fortemente das características hidrodinâmicas do solo, isto é, de seu funcionamento e que este, por sua vez, depende de suas características físicas, químicas e mineralógicas, são objetivos do presente estudo:

-.caracterizar os parâmetros que possam esclarecer a dinâmica destes solos ;

- contribuir para a definição de critérios que regulamentem a aptidão de solos como sistema depurador.

Estes objetivos serão alcançados através de análises granulométricas, químicas, mineralógicas e micromorfológicas, buscando as principais evidências que possam definir a organização destes solos. 


\section{REVISÃO DE LITERATURA}

Os solos da área de estudo desenvolvem-se sobre sedimentos da Formação Adamantina (Grupo Bauru), sendo a revisão da literatura sobre esta formação geológica necessária para a compreensão da gênese destes solos. Isto é ainda mais importante, pelo fato de que a região estudada é desprovida de afloramentos desta formação.

\subsection{Distribuição e caracterização da Formação Adamantina}

A Formação Adamantina é a unidade de maior distribuição em superfície no Estado de São Paulo (IPT, 1981), ocupando a maior parte do Planalto Ocidental. Seus afloramentos ocorrem no oeste e centro-oeste do Estado de São Paulo, no Triângulo Mineiro, sul de Goiás e sudeste de Mato Grosso (Petri \& Fúlfaro,1983) (Figura 1).

Os depósitos relacionados á Formação Adamantina, fazem parte de unidades sedimentares suprabasálticas de Idade Cretácea, anteriormente consideradas "grez" de Bauru, Formação Bauru, Série Bauru e Grupo Bauru (IPT, 1981).

Coimbra (1977) caracterizou os sedimentos do Grupo Bauru, até então denominado Formação Bauru, através da análise de minerais pesados, granulometria e calcimetria, definindo através destes parâmetros suas áreasfonte. A Formação Baurú foi dividida em 3 unidades: Fácies A (inferior), cujos sedimentos se originaram a partir da erosão de rochas básicas da Formação Serra Geral (Grupo São Bento) e rochas metamórficas do Grupo Araxá- 
Canastra e Fácies B (intermediária) e Fácies C (superior), ambas constituídas por sedimentos que se originaram de rochas metamórficas, sedimentos préexistentes paleo-mesozóicos da Bacia do Paraná e rochas básicas da Formação Serra Geral. A Fácies B teve ainda contribuição de rochas alcalinas mesozóicas do Triângulo Mineiro, cuja particularidade é a presença do mineral pesado perowskita. Os minerais pesados transparentes identificados foram: na fácies $\mathrm{A}$, augitas e granadas, na fácies $\mathrm{B}$, perowskita, augita, epidoto, granada, turmalina e zircão e na fácies $C$, granada, epidoto, zircão, turmalina, rutilo e augita.

Em relação à maturidade mineralógica dos sedimentos da Formação Bauru, este autor verificou que na fração $0,125-0,062 \mathrm{~mm}$, ocorrem iguais proporções de minerais de alta estabilidade, como zircão e turmalina, e minerais meta-estáveis, como granada e augita, classificando o sedimento como mineralogicamente imaturo. Quanto à calcimetria, concluiu que o teor de carbonato de cálcio no cimento dos arenitos desta Formação, não era válido como critério estratigráfico, pois seria autígeno, originado a partir de alterações intra-estratais de augitas.

Soares et al. (1980) caracterizaram as diferentes unidades genéticas mapeáveis e definiram o Grupo Baurú, constituído pelas Formações Caiuá, Santo Anastácio, Adamantina e Marília.

A Formação Adamantina foi formalmente proposta como denominação a um conjunto de fácies cuja principal característica é a presença de bancos de arenitos de granulação fina à muito fina, cor róseo à castanho, apresentando estratificação cruzada, com espessuras variando entre 2 e 20 metros, alternados com bancos de lamitos, siltitos e arenitos lamíticos, de cor castanhoavermelhado a cinza-castanho, maciços ou com acamamento plano-paralelo grosseiro, frequentemente com marcas de onda e microestratificação cruzada. 


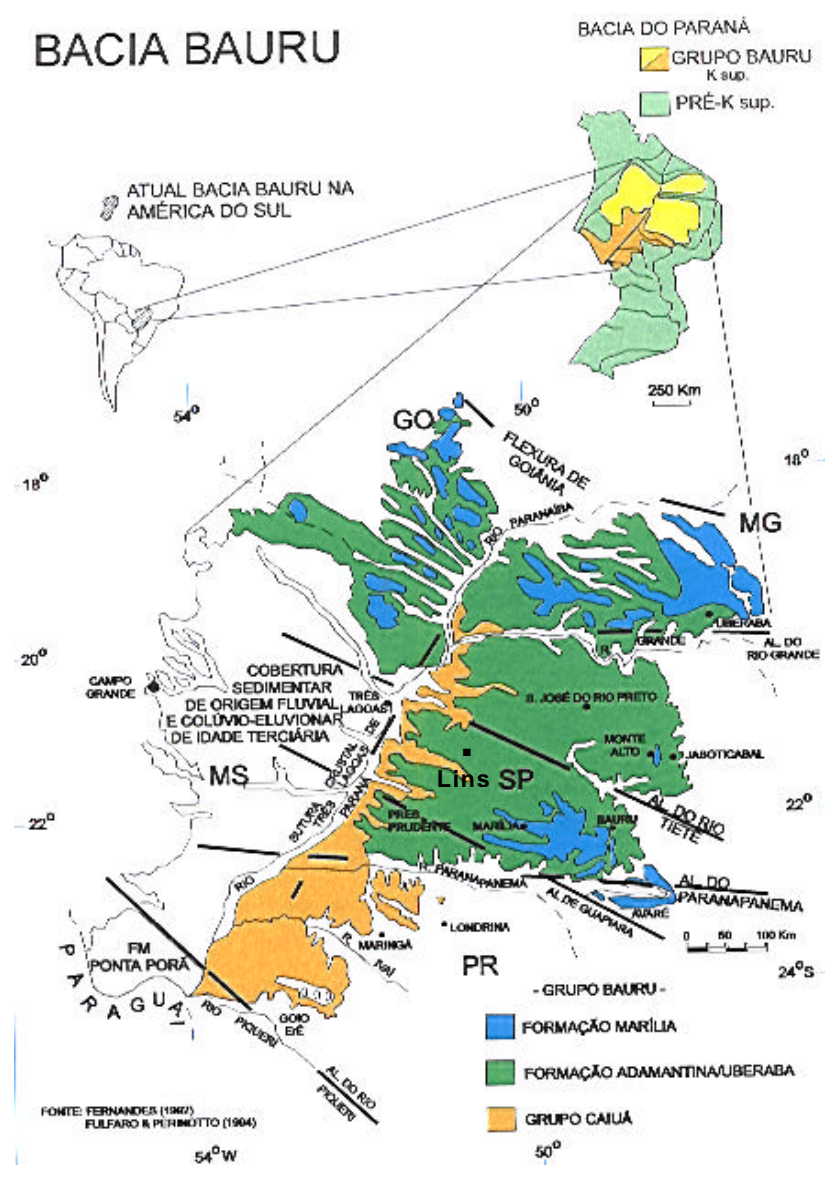

Figura 1 - Mapa de distribuição das unidades do Grupo Bauru. Fonte: Fúlfaro \& Perinotto (1996), modificado.

Seu contato basal é concordante sobre a Formação Santo Anastácio e discordante sobre os basaltos da Formação Serra Geral (Soares et al.,1980).

Considerando-se as diferentes fácies deposicionais, conclui-se que a Formação Adamantina foi depositada em um extenso sistema fluvial meandrante, dominantemente pelítico a sul, gradando para psamítico a leste e 
norte, com transição para anastomosado. Os arenitos com estratificação cruzada passando a maciços e plano-paralelos representam depósitos em barras de pontal ou transversais realizados nos canais. Os lamitos e siltitos foram depositados nas planícies de inundação, várzeas e lagoas, e os arenitos ricos em microestratificação cruzada por rompimento de diques marginais e espraiamento sobre a planície (Soares et al.,1980).

Fúlfaro \& Perinotto (1996) observam que, somente a partir da década de 90, foram realizadas revisões da coluna litoestratigráfica proposta em 1980, até então em vigor, sendo que a área de ocorrência do Grupo Bauru começou a ser denominada de Bacia Bauru.

\subsection{Solos desenvolvidos a partir dos sedimentos do Grupo Bauru}

De acordo com o Levantamento de Reconhecimento de Solos do Estado de São Paulo (Brasil, 1960), os solos do Planalto Ocidental Paulista foram desenvolvidos a partir dos sedimentos do Grupo Bauru e classificados como pertencentes a três grandes grupos: Solos Podzolizados variação Lins, Solos Podzolizados variação Marília e Latossolo Vermelho-Escuro fase arenosa, além do Litossolo fase substrato arenito-calcário e Solos Hidromórficos. O principal diferencial entre eles é o material de origem, pois os solos podzolizados seriam desenvolvidos a partir de arenitos com cimento calcário (Formação Marília), tendo alta saturação de bases, enquanto os latossolos seriam originados a partir do arenito Baurú sem cimento calcário (Formação Adamantina). Estes três grandes grupos são encontrados formando manchas contínuas associadas geograficamente entre si e frequentemente apresentam-se como sendo de transição podzólico-latossólico.

Cabe aqui ressaltar, que a partir do Levantamento de Reconhecimento de Solos do Estado de São Paulo (Brasil, 1960) e da compilação de informações resultantes de vários levantamentos de solos executados em diversas escalas nos anos subsequentes, foi elaborado o "Mapa Pedológico do 
Estado de São Paulo" (Oliveira et al., 1999), cuja nomenclatura taxonômica foi atualizada com base no Sistema Brasileiro de Classificação de Solos (EMBRAPA, 1999).

Sendo assim, os antigos grandes grupos citados, classificados anteriormente como Solos Podzolizados variação Lins e variação Marília, passaram para ARGISSOLOS VERMELHO-AMARELO ou VERMELHO ou AMARELO Eutróficos ou Distróficos. Os Latossolos Vermelho-Escuro fase arenosa passaram para LATOSSOLO VERMELHO Eutrófico ou Distrófico (Oliveira, 1999).

Os solos do Planalto Paulista foram alvo de inúmeras pesquisas durante as décadas de 70 e 80 , principalmente pelo fato de ocorrerem solos com transição abrupta, onde os horizontes A são pouco espessos, levando alguns autores a propor origem coluvionar destes horizontes (Queiroz Neto et al., 1973; Penteado \& Ranzani, 1973; Carvalho, 1976).

Uma das conclusões a que vários autores chegaram (Queiroz Neto et al.,1973; Moniz \& Carvalho,1973; Lepsch,1975; Carvalho,1976; Perecin \& Campos,1976; Queiroz Neto et al.,1981) é a de que os solos podzolizados ocorrem nas diferentes posições do relevo e que eles se desenvolvem tanto sobre os sedimentos da Formação Marília quanto sobre os sedimentos da Formação Adamantina, embora o Levantamento de Reconhecimento de Solos do Estado de São Paulo (Brasil, 1960) demonstre uma nítida correlação espacial entre as manchas dos podzolizados e a Formação Marília, como apresentada no Mapa Geológico do Estado de São Paulo (IPT, 1981).

Moniz \& Carvalho (1973) estudaram 24 perfis de solo em uma topossequência localizada no extremo noroeste do Estado de São Paulo, onde ocorrem arenitos das formações Adamantina e Santo Anastácio. Através da sua evolução mineralógica, desde os estágios iniciais de alteração dos arenitos do Bauru até a formação dos Latossolos, estabeleceram a correlação entre o desenvolvimento destes solos e a evolução geomorfológica 
da região, inserindo-os em uma vertente compartimentada segundo o modelo de Ruhe ${ }^{1}$.

Segundo estes autores, os Solos Podzolizados variação Marília estariam relacionados às partes altas do Planalto e seriam formados sobre 0 arenito Bauru, praticamente sem recobrimento cenozóico, sendo seus teores de caulinita situados entre 30 e $70 \%$. Os Solos Podzolizados variação Lins, ocupariam posição correspondente ao pedimento de encosta e teriam se desenvolvido a partir de recobrimento tipo coluvial previamente alterado, sendo seus teores de caulinita entre 70 e $80 \%$ e os Latossolos ocupariam as posições de sopé de encosta e seriam desenvolvidos a partir de recobrimento espesso do tipo pedimentar, indicando estágio mais avançado de intemperismo através dos teores de caulinita entre 80 e $90 \%$.

Ainda, estes autores apresentaram análise granulométrica dos solos desenvolvidos sobre o "Arenito Bauru" no extremo noroeste do Estado de São Paulo, onde os perfis apresentaram bom grau de seleção e são constituídos por partículas finas a muito finas ( classes texturais 0,250-0,125 mm e 0,125-0,053 $\mathrm{mm})$.

Cabe ressaltar que a topossequência descrita por Moniz \& Carvalho (1973), onde os Latossolos ocorrem no sopé de encosta, é contrária à grande maioria das sequências Latossolo-Argissolo estudadas, ás quais a transição lateral de Latossolos para Argissolos ocorre de montante para jusante nas vertentes (Lepsch \& Buol, 1974; Lepsch et al., 1977; Queiroz Neto et al., 1981; Moniz \& Buol, 1982; Castro,1989; Vidal-Torrado \& Lepsch, 1993; Vidal-Torrado et al.,1999). A associação Latossolo-Argissolo é uma das mais estudadas no Estado de São Paulo e uma das mais frequentes nos planaltos bem drenados localizados nas regiões tropicais úmidas, onde características dos horizontes latossólico e textural quase sempre ocorrem no mesmo perfil (Lepsch \& Buol, 1974).

${ }^{1}$ RUHE, R.V. Elements of the soil landscape. In: International Congress of Soil Science, 7, Madison, EUA, 1960. Transactions. v. 4 , p. $165-170$ 
Lepsch², citado por Carvalho (1976), estudou na área de Echaporã (SP), localizada na porção sul do Planalto Ocidental Paulista, as relações entre os solos e os elementos da paisagem, constatando que os latossolos relacionamse às superfícies mais planas e mais antigas, enquanto os argissolos estão presentes nas vertentes mais íngremes e mais jovens. $O$ aparecimento do horizonte argílico seria devido a movimentos laterais de água nos horizontes superficiais, que criariam condições anaeróbias, provocando a redução do ferro, que seria removido do perfil e a argila poderia migrar em profundidade, sendo uma das evidências, os valores mais elevados da relação ferro/argila nos horizontes $\mathrm{A} 2$, quando comparados com os horizontes argílicos subjacentes. Esta hipótese não considera a possibilidade desta variação estar relacionada a discontinuidades litológicas.

Carvalho (1976), caracterizou e definiu a evolução dos solos situados próximo ao município de Marília, em área de cerca $100 \mathrm{Km}^{2}$ e constatou a existência de uma cobertura superficial generalizada de material essencialmente arenoso, caracterizado como colúvios relativamente modernos. Este material foi identificado como sendo os horizontes $A$ e os horizontes inferiores $B$ textural, B latossólico e/ou $C$, como solos enterrados ou fósseis. Estes paleossolos também foram desenvolvidos sobre material de cobertura numa fase pedogenética anterior. Nesta fase, os latossolos foram desenvolvidos primeiro, a partir da instalação de climas quentes e úmidos do início do Neogeno. Ainda durante o Pleistoceno, teve início uma fase caracterizada por processos de argiluviação que afetou toda a área, seguindose fases erosivas que removeram os horizontes $A$, sucedidas por nova pedogênese. Os horizontes $A$ dos perfis atuais corresponderiam á última fase de coluvionamento, provavelmente já no Holoceno.

Queiroz Neto et al. (1981), constataram a transformação pedológica de horizontes $B$ latossólicos em $B$ texturais devido á circulação vertical e lateral de água ao longo das topossequências, através de mecanismos de segregação do ${ }^{2}$ LEPSCH, I.F. 1975. Soil-landscape relationships in an area of the Occidental Plateau of São Paulo, Brazil. Raleigh, 1975. Thesis (PhD),. North Caroline University. 
ferro das ligações ferro/argila na zona de transição entre os horizontes $\mathrm{A}$ e B e iluviação de argila em B, corroborando as observações de Lepsch (1975).

Moniz \& Buol (1982), através do estudo da gênese de uma transição Latossolo - Argissolo, em Atibaia (SP), concluíram que a formação dos horizontes argílicos a partir de horizontes latossólicos se dá através de deformações plásticas, induzidas por alternância de ciclos de umedecimento e secamento dos solos. Num determinado estágio, em superfícies com declividade, instala-se o fluxo lateral, capaz de manter os solos úmidos por um certo tempo após cessadas as precipitações. Isto provoca expansão do material e diminuição da porosidade, gerando coesão entre porções individualizadas de solo. Durante o secamento, começam a se formar fendas de contração (fissuras). Os agregados são formados a partir destas fissuras de dissecação durante a desidratação, quando a força de tensão é superada. Estas fendas são fechadas durante novo ciclo de umedecimento, gerando alta pressão. Em consequência, as partículas grosseiras no contato entre os agregados, são pressionadas para dentro, concentrando partículas finas na superfície dos agregados, rearranjando os minerais de argila, originando cerosidade.

$O$ acentuado gradiente textural dos solos podzolizados desenvolvidos a partir da Formação Marília foi atribuído por Rueda \& Dematte (1988) principalmente devido a camadas lamíticas do material de origem e em parte, atribuído a um processo de degradação do horizonte $\mathrm{B}$ textural por remoção lateral e/ou destruição das argilas.

De acordo com Castro (1989), que estudou os sistemas de transformação B latossólico - B textural em Marília (SP), os mecanismos de transferência de matéria são evidenciados através de estruturas de degradação e de agradação. São consideradas as seguintes características de degradação observadas no topo das vertentes: desmantelamento da estrutura porfírica e nascimento das estruturas quitônica, enáulica e mônica por perda de plasma; presença de agregados pedoherdados do Bw nos horizontes superiores de perfis na meia encosta, já degradados e preenchidos por argila; fragmentação, 
fissuração e dissolução de esqueleto quartzoso, além de seu acúmulo residual; aumento da porosidade; degradação ascendente das caulinitas nos perfis, entre outros. As estruturas de agradação são: reorganização da estrutura porfírica por preenchimento dos poros; cutãs de iluviação preenchendo macroporos, com posterior zoneamento por segregação de ferro; preservação do esqueleto quartzoso; diminuição da porosidade, entre outros.

Este autor concluiu que o material de origem dos solos podzolizados seria um latossolo resultante da ferralitização do arenito Baurú e que estes podzolizados estariam em processo de degradação, podendo tratar-se de uma cobertura pedológica com pelo menos dois estados de desequilíbrio com o meio: um, que originou o aprofundamento do nível de base permitindo o desenvolvimento de intensa circulação lateral responsável pela formação dos solos podzolizados, desequilibrando os latossolos pré-existentes e outro, que estaria distribuindo os solos podzolizados por erosão geoquímica e erosão superficial.

Carvalho (1976), Lepsch et al. (1977a,b) e Castro (1989) constataram a ausência de gibbsita nos solos desenvolvidos a partir dos sedimentos do Grupo Baurú. Os dois primeiros autores explicam este fato, que é incomum nos latossolos brasileiros, através de duas hipóteses:

1. O material de origem destes solos seriam sedimentos retrabalhados do próprio Grupo Baurú e seriam bem mais jovens que as superfícies geomorfológicas em que se depositaram ou;

2. O quartzo em abundância protegeu a caulinita, inibindo a formação de gibbsita, num sistema em que a sílica em solução é relativamente elevada (Fritz \& Tardy, 1976). 


\section{MATERIAIS E MÉTODOS}

\subsection{Caracterização do meio físico}

A área de estudo situa-se junto ao sistema de lagoas de estabilização da Estação de Tratamento de Esgotos (ETE) do município de Lins/SP (22ํำ $\left.21^{\prime} \mathrm{S} / 49^{\circ} 50^{\prime} \mathrm{W}\right)$, onde está instalada a área experimental, ocupando cinco hectares e encravada numa vertente com ligeira inclinação, terminando no Córrego Campestre (Figura 2).

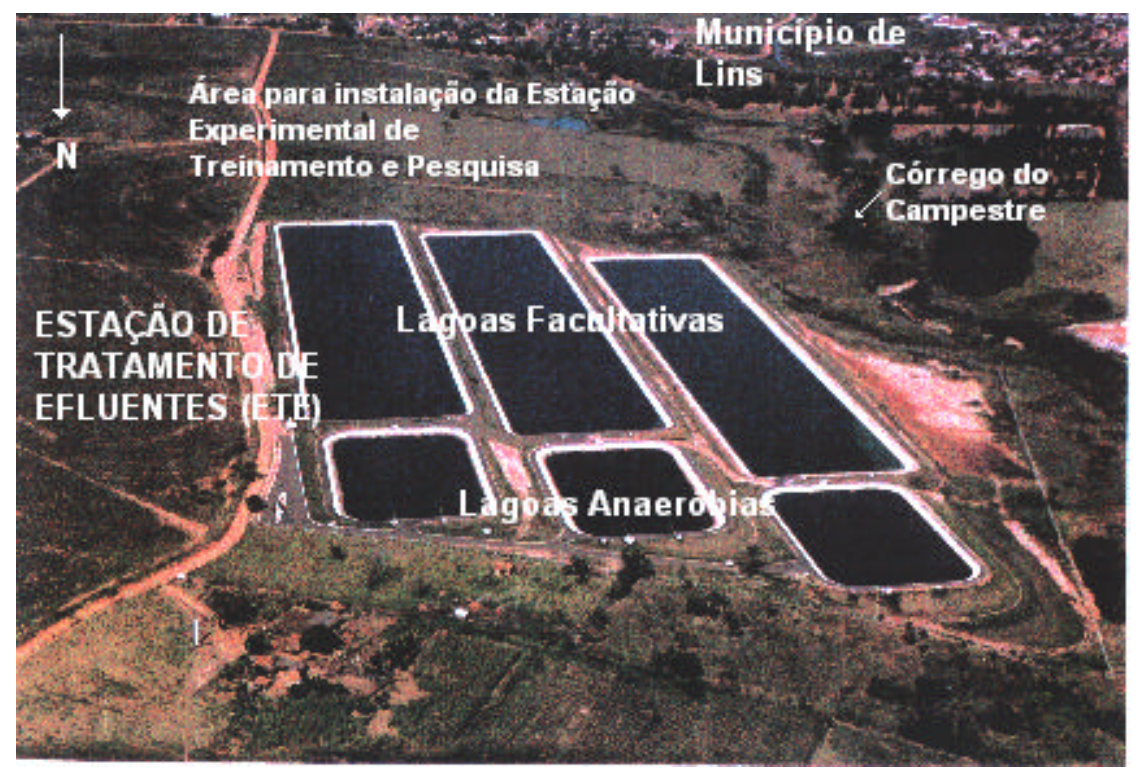

Figura 2 - Vista geral da Estação de Tratamento de Esgotos (ETE) do município de Lins (SP). Em primeiro plano, observa-se o sistema de tratamento de efluentes por lagoas de estabilização e ao fundo a área de estudo. 
O município de Lins encontra-se na zona climática Cwa, caracterizada como mesotérmico de inverno seco, segundo a classificação de Koppen. A temperatura média é de $22^{\circ} \mathrm{C}$ no mês mais quente e $18^{\circ} \mathrm{C}$ no mês mais frio e a precipitação anual varia entre 1.100 e 1.300 mm, sendo que no mês mais seco, a precipitação é menor que $30 \mathrm{~mm}$.

A vegetação natural da região é a floresta latifoliada semidecídua, porém, esta cobertura vegetal foi quase totalmente substituída devido ao intenso uso do solo. Cerca de $70 \%$ da área rural do município é ocupada por pastagens e o restante, por culturas como cana-de-açúcar e milho.

Geologicamente, a área de estudo situa-se sobre a Formação Adamantina (Cretáceo Superior), pertencente ao Grupo Baurú, inserida na Bacia sedimentar do Paraná (IPT,1981a) e localmente caracterizada por banco de arenito de granulação fina a muito fina, moderadamente selecionado, com espessura superior a 3 metros.

Geomorfologicamente, a região encontra-se no Planalto Ocidental Paulista, que abrange 50\% do Estado de São Paulo. O relevo dominado pelo Grupo Baurú é, de modo geral, extremamente suave, levemente ondulado, exceto nas proximidades das cuestas basálticas (IPT, 1981b).

A área de estudos encontra-se em relevo suavemente ondulado, onde a vertente tem ligeira declividade.

De acordo com o Mapa Pedológico do Estado de São Paulo (Oliveira et al., 1999), a região apresenta solos classificados como ARGISSOLO VERMELHO-AMARELO eutrófico e ARGISSOLO VERMELHO distrófico e eutrófico, ambos com textura arenosa/média, relevo suavemente ondulado. São solos constituídos por argilas de baixa atividade e horizonte $B$ textural imediatamente abaixo de horizonte $\mathrm{A}$ ou $\mathrm{E}$, sendo fortemente arenosos. $\mathrm{Na}$ região de Lins, os solos têm caráter espessoarênico e mudança textural abrupta, o que Ihes confere maior susceptibilidade á erosão (Oliveira,1999). 


\subsection{Escolha das topossequências e locais de amostragem dos solos}

O estudo dos solos existentes na vertente foi realizado seguindo algumas etapas da metodologia da análise tridimensional (Boulet et al., 1984).

Inicialmente, foram selecionadas duas topossequências ( $A$ e $B$ ), segundo os eixos de maior declive da vertente, cujas extensões abrangeram toda a área de estudo. Ao longo das mesmas, foram executadas 11 tradagens do topo até a base da vertente, com o propósito de identificar prováveis variações morfológicas na área e determinar os pontos de abertura das trincheiras. As tradagens foram executadas com trado manual tipo holandês até a profundidade de 3,0 metros e as amostras, coletadas em intervalos de 0,2 m, acondicionadas em pedocomparadores.

A partir das descrições das amostras coletadas nas tradagens, foram selecionados seis locais para abertura de trincheiras. Do topo para a base da vertente, os perfis ficaram assim distribuídos: na topossequência $A$, localizamse os perfis $\mathrm{P} 1, \mathrm{P} 3, \mathrm{P} 2$ e $\mathrm{P} 4$ e na topossequência $\mathrm{B}$, localizam-se os perfis $\mathrm{P} 3$, P5 e P6 (Figura 3).

Os seis perfis foram descritos de acordo com as normas estabelecidas pelo Manual de Descrição e Coleta de Solos no Campo (Lemos \& Santos, 1984). Todos os horizontes foram amostrados, sendo coletadas amostras para as análises físicas, químicas e mineralógicas. Amostras indeformadas e orientadas foram coletadas para análises micromorfológicas.

Os solos foram classificados de acordo com o Sistema Brasileiro de Classificação de Solos (EMBRAPA, 1999). 


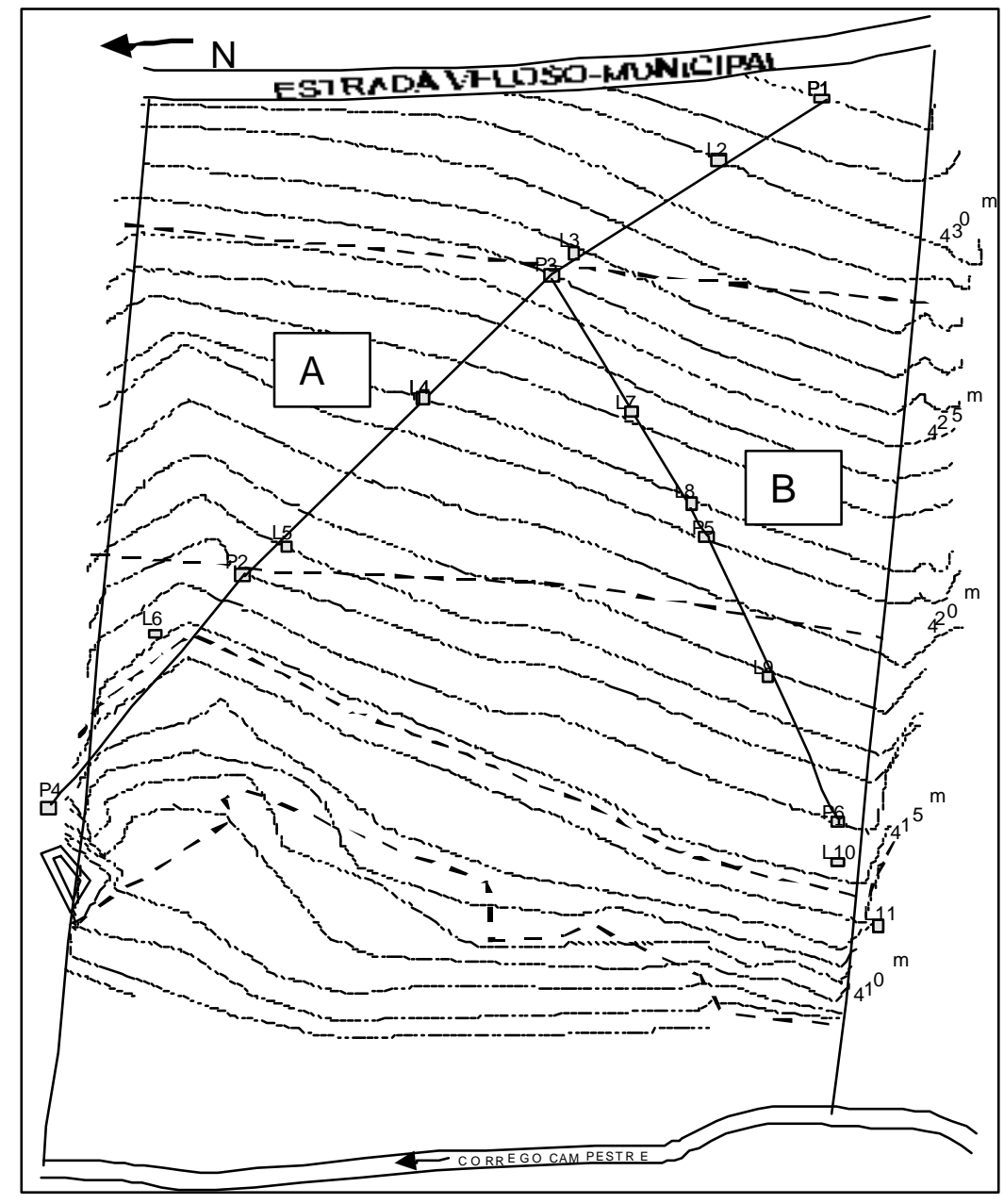

Figura 3 - Croqui da área de estudo, no município de Lins (SP), mostrando a localização das topossequências $A$ e $B$, selecionadas segundo o eixo de maior declividade da vertente. $L$ - tradagens; $P$ - trincheiras. 


\subsection{Análises das amostras de solo}

No Laboratório de Preparação de Amostras do NUPEGEL ESALQ/USP, as amostras coletadas nas trincheiras foram secadas ao ar e peneiradas em malha de $2 \mathrm{~mm}$ de abertura, obtendo a fração terra fina seca ao ar (TFSA). Estas amostras foram submetidas à análises granulométrica e química.

\subsubsection{Análise granulométrica}

A análise granulométrica foi realizada através do método da pipeta (Camargo et al., 1986), Utilizou-se como dispersante, solução de hidróxido de sódio $0,167 \mathrm{~N}$ (6,68 g de hidróxido de sódio para $1000 \mathrm{ml}$ de água destilada). Todas as frações granulométricas foram recuperadas para análise mineralógica.

\subsubsection{Análises químicas}

Foram realizadas análises químicas do complexo adsorvente e análises dos elementos maiores e traços das amostras de TFSA.

Para a caracterização do complexo adsorvente, seguiram-se as metodologias recomendadas por Raij et al. (1987). Foram medidos pH em água, em $\mathrm{CaCl}_{2}$ 0,01M e em KCl 1M. Os cátions trocáveis ( $\mathrm{Na}, \mathrm{K}, \mathrm{Ca}$ e $\mathrm{Mg}$ ) e $\mathrm{P}$ foram obtidos através do método de resina de troca iônica. $O$ alumínio trocável foi determinado utilizando-se como solução extratora $\mathrm{KCl} 1 \mathrm{M}$. A matéria orgânica foi determinada pelo método Walkley-Black (oxidação do carbono orgânico por dicromato na presença de ácido sulfúrico concentrado). A acidez potencial $(\mathrm{H}+\mathrm{Al})$ foi obtida por extração com acetato de cálcio $1 \mathrm{~N}$ a pH 7,0.

Destas determinações foram obtidos os seguintes parâmetros: soma de bases $(\mathrm{SB}=\mathrm{Na}+\mathrm{K}+\mathrm{Ca}+\mathrm{Mg})$, capacidade de troca de cátions $(\mathrm{T}=\mathrm{SB}+\mathrm{H}+$ $\mathrm{Al}$ ) e porcentagem de saturação em bases $(\mathrm{V}=(\mathrm{SB} / \mathrm{T}) \times 100))$.

As análises químicas dos elementos maiores e traços foram realizadas por fluorescência de raios-X. A determinação foi feita nas amostras após fusão 
com tetraborato de lítio, sendo realizadas no laboratório da Lakefield Geosol (Belo Horizonte/MG), seguindo as recomendações do Soil Survey Laboratory Information ( Estados Unidos, 1996).

\subsection{Análises mineralógicas}

\subsubsection{Fração argila}

A mineralogia da fração argila foi determinada através do método de difração de raios-X. Para serem difratadas, foram utilizadas amostras em estado natural, condicionadas em amostrador tipo "janela" (método do pó). Parte das amostras coletadas, foram submetidas ao processo de deferrificação para a confirmação da presença de hematita, magnetita e/ou maghemita Os difratogramas de raios- $\mathrm{X}$ foram obtidos com tubo de ânodo de $\mathrm{Cu}$, no intervalo de varredura de 3 a $65^{\circ} 2 \theta$.

\subsubsection{Minerais pesados}

A identificação dos minerais pesados foi realizada na fração areia muito fina (entre 0,106 e 0,053 mm). A escolha desta fração foi baseada nos estudos de Coimbra (1977) que, comparando as frequências relativas dos minerais transparentes não micáceos do Grupo Bauru em duas frações granulométricas $(0,250-0,125 \mathrm{~mm}$ e 0,125-0,062 $\mathrm{mm})$, verificou que alguns minerais, como zircão, rutilo e apatita apresentam frequências mais altas na última fração, enquanto turmalina, granada, estaurolita e cianita apresentam frequências mais altas na fração $0,250-0,125 \mathrm{~mm}$.

A separação foi feita por gravimetria, utilizando-se o bromofórmio como meio líquido, seguindo o método de Carver (1971). O bromofórmio é geralmente usado pelo fato de sua densidade $(\mathrm{d}=2,85 \mathrm{~g} / \mathrm{ml}$ a $2,88 \mathrm{~g} / \mathrm{ml}$ ) ser considerada como o limite clássico de separação entre os constituintes leves e pesados.

Para aumentar a concentração dos minerais pesados transparentes, os opacos magnéticos foram parcialmente eliminados com imã manual. Para a 
análise qualitativa e contagem no microscópio óptico, foram usadas montagens não permanentes em lâminas com líquido viscoso com índice de refração 1,61.

Foram analisadas três amostras de cada perfil, sendo a primeira do horizonte superficial, a segunda de horizonte intermediário ( preferencialmente entre 80 e $100 \mathrm{~cm}$ ) e a terceira do horizonte mais profundo.

A contagem foi realizada por quadrantes, no campo de visão do microscópio, onde foram contados até 100 grãos de opacos e depois mais 100 de não-opacos.

\subsection{Micromorfologia}

Foram coletadas 30 amostras indeformadas nos horizontes dos perfis P1 a P6, porém, só foi possível a confecção de 23 lâminas, devido á problemas na impregnação das amostras.

As amostras indeformadas foram coletadas com auxílio de caixas de papelão de $6 \times 10 \times 5 \mathrm{~cm}$, orientadas, secadas inicialmente ao ar e depois em estufa a $45^{\circ} \mathrm{C}$ por 48 horas e posteriormente impregnadas com mistura de resina poliester Cristal e diluente monômero de estireno, com gotas do catalisador Butanox. A montagem e polimento das amostras em lâminas foi realizada segundo o Manual de Métodos de Análise de Solo (EMBRAPA, 1997).

As análises micromorfológicas foram feitas em microscópio ótico Zeiss e os procedimentos e nomenclaturas para as descrições das lâminas foram feitas de acordo com Bullock et. al. (1985). 


\section{RESULTADOS E DISCUSSÃO}

Os perfis são apresentados sequencialmente do topo para a base da vertente, conforme a Figura 3. Os perfis P1, P3, P2, e P4 estão na topossequência $A$ e os perfis P3, P5 e P6 na topossequência B (Figuras 4 e 5).

A classificação dos solos é apresentada nesta introdução para facilitar a leitura, em função da importância de algumas características apresentadas que são inerentes aos tipos de solos identificados.

A partir das descrições dos perfis e respectivas análises das amostras coletadas nos horizontes, são classificados 5 tipos de solos na área de estudo, assim distribuídos do topo para a base da vertente: (i) LATOSSOLO VERMELHO Distrófico típico (perfis P1 e P3); (ii) ARGISSOLO VERMELHO Distrófico latossólico (perfil P5); (iii) ARGISSOLO VERMELHO-AMARELO Distrófico latossólico (perfil P2); (iv) ARGISSOLO VERMELHO Distrófico abrúptico (perfil P6) e (v) ARGISSOLO AMARELO Distrófico abrúptico (perfil P4).

\subsection{Características morfológicas dos perfis}

As descrições morfológicas completas dos perfis encontram-se no Apêndice 1, sendo que no texto são apresentadas as principais características. 


\section{Perfil P1}

LATOSSOLO VERMELHO Distrófico típico: localiza-se no topo da vertente, dividido em 4 horizontes até a profundidade de $130 \mathrm{~cm}$. Os horizontes BA, Bw1 e Bw2 são caracterizados pela textura franco-arenosa, cor vermelho a vermelho escuro, estrutura em blocos subangulares médios de grau fraco, que se desfazem facilmente em agregados granulares de grau forte. No Bw1 e Bw2 (a partir de $30 \mathrm{~cm}$ de profundidade), aparecem pontos de areia lavada, de cor branca, constituindo volumes pouco definidos e quantidade pouco representativa. A macroporosidade é intensa e constante ao longo do perfil, assim como a presença de raízes finas e médias. A atividade biológica também é intensa, observando-se muitas câmaras e canais centimétricos.

\section{Perfil P3}

LATOSSOLO VERMELHO Distrófico típico: situa-se a aproximadamente 100 metros de P1 no terço superior da vertente, dividido em 7 horizontes até a profundidade de $230 \mathrm{~cm}$. Apresenta-se muito semelhante ao perfil anterior, onde os horizontes Bw1 a Bw5 tem estrutura em blocos subangulares de grau fraco a moderado e predomínio da cor vermelha. A textura dos horizontes subsuperficiais é franco-argilo-arenosa até Bw3 $(170 \mathrm{~cm})$, passando para franco-arenosa. Apresenta maior quantidade de areia lavada que o perfil $\mathrm{P} 1$, ocorrendo a partir do Bw1 $(20 \mathrm{~cm})$ até a base do perfil, onde chegam a constituir bandas contínuas brancas. Intensa ocorrência de raízes até Bw3 (170 $\mathrm{cm}$ ), a partir daí diminuem muito, assim como a macroporosidade. Presença de câmaras e canais principalmente até $50 \mathrm{~cm}$.

\section{Perfil P5}

ARGISSOLO VERMELHO Distrófico latossólico: localiza-se a 120 metros de P3 na meia encosta, dividido em 7 horizontes, até a profundidade de 210 $\mathrm{cm}$. A textura é areia-franca nos horizontes $A$ e $A B$ e franco-argilo-arenosa nos demais. No horizonte $A B$, ocorrem poucos volumes mais escuros e 
avermelhados 2,5 YR 4/4. Os horizontes Bt1 a Bt3 (até $200 \mathrm{~cm}$ ) tem estrutura em blocos subangulares de grau moderado a fraco, passando no Bw para grau fraco, que se desfaz em agregados granulares. A macroporosidade é intensa em todo o perfil. Presença de areia lavada a partir de $50 \mathrm{~cm}$. Ocorrência de raízes até $160 \mathrm{~cm}$. Atividade biológica mais intensa até $56 \mathrm{~cm}$, observando-se canais e câmaras.

\section{Perfil P2}

ARGISSOLO VERMELHO-AMARELO Distrófico latossólico: localiza-se a aproximadamente 130 metros de P3 no terço inferior da vertente, dividido em 6 horizontes, até a profundidade de $230 \mathrm{~cm}$.. A textura do horizonte A é areiafranca e dos horizontes subsuperficiais é franco-argilo-arenosa, com estrutura em blocos subangulares de grau fraco que se desfazem em agregados granulares. Até atingir o horizonte glei, o perfil é muito homogêneo, com aspecto latossólico. O horizonte Bt1 é mais compacto que Bt2 e Bt3, que são muito friáveis. Observam-se porções de areia lavada até o Bt3. Ocorrência de horizonte glei a partir de $210 \mathrm{~cm}$, apresentando mosqueados com cor de fundo $5 Y R$ 6/1 e 5YR 6/2. As raízes ocorrem até $20 \mathrm{~cm}$ e a porosidade é mais intensa até $75 \mathrm{~cm}$.

\section{Perfil P6}

ARGISSOLO VERMELHO Distrófico abrúptico: localiza-se a 120 metros de P5 e situa-se no terço inferior da vertente, logo após uma ligeira quebra de relevo, dividido em 7 horizontes até a profundidade de $240 \mathrm{~cm}$. A textura dos horizontes $A$ e $A B$ é areia-franca e dos horizontes subsuperficiais é francoargilo-arenosa. Os horizontes Bt1 e Bt2 tem estrutura em blocos subangulares de grau moderado e tamanho médio que se rompem em blocos pequenos. De Bt3 a Btg a estrutura é muito fraca, difícil de ser definida. Próximo a $90 \mathrm{~cm} \mathrm{e}$ abaixo de $205 \mathrm{~cm}$, ocorrem concreções mili a centimétricas pretas, duras, podendo ser cortadas com canivete. No horizonte Bt4 $(165-205 \mathrm{~cm})$, aparecem 
mosqueados que se tornam mais intensos no horizonte Btg $(205+\mathrm{cm})$. Porosidade intensa em todo o perfil. Ocorrência de raízes até o topo de Bt3, neste horizonte é grande a presença de câmaras decimétricas.

\section{Perfil P4}

ARGISSOLO AMARELO Distrófico abrúptico: localiza-se a aproximadamente 60 metros de P2 e situa-se no sopé da vertente, dividido em 5 horizontes até a profundidade de $155 \mathrm{~cm}$, onde foi atingido o lençol freático. A textura é areia-franca nos horizontes $A$ e franco-argilo-arenosa nos horizontes subsuperficiais. Os horizontes Bt1 e Bt2 tem estrutura em blocos subangulares de grau fraco a maciça e o horizonte Btg estrutura maciça. A partir de Bt2, aparecem manchas claras ao longo dos poros e raízes, indicando início de hidromorfismo, definindo horizonte glei partir de $94 \mathrm{~cm}$. Ocorrem muitos poros médios e grandes até o lençol freático.

As características morfológicas são muito homogêneas em todos os solos analisados, sendo as mais evidentes, a presença intensa de poros ao longo de todos os perfis e o aspecto granular destes solos.

A porosidade é constituída por muitos poros muito pequenos $(<0,1 \mathrm{~cm}$ de diâmetro) a médios (de 0,2 a $0,5 \mathrm{~cm}$ de diâmetro) e poros comuns grandes (de 0,5 a 1,0 cm de diâmetro). Também é frequente a presença de câmaras, com dimensões que variam entre 5,0 e $20,0 \mathrm{~cm}$, preenchidas pelo material adjacente, composto pelos agregados granulares.

A estrutura predominante é granular pequena (de 0,1 a $0,2 \mathrm{~cm}$ ), fortemente desenvolvida. Em alguns horizontes de perfis argissólicos, quando ocorre estrutura em blocos subangulares, esta varia de pequena à média, porém, é fracamente desenvolvida, se desagregando, com ligeira pressão dos dedos, em agregados granulares pequenos. 


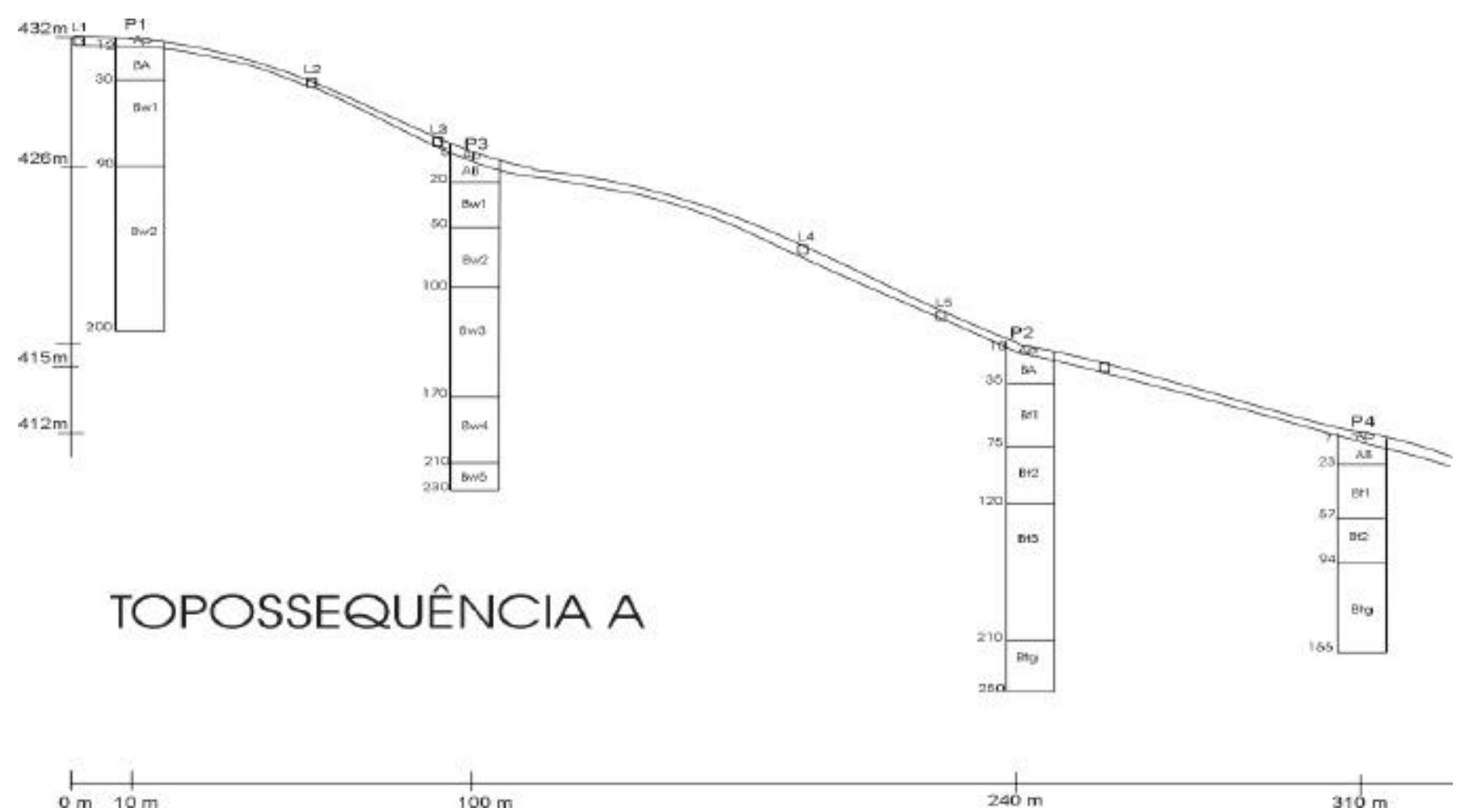

$\stackrel{\circ}{\text { Figura }} 4$ - Topossequência $\mathrm{A}^{100 \mathrm{~m}}$ estudada no município de Lins (SP), apresentando a posição dos perfis P1, P3, P2 e P4, respectivas distribuições dos horizontes e localização dos pontos de tradagens L1, L2, L3, L4 e L5. A profundidade dos perfis está em centímetros. 


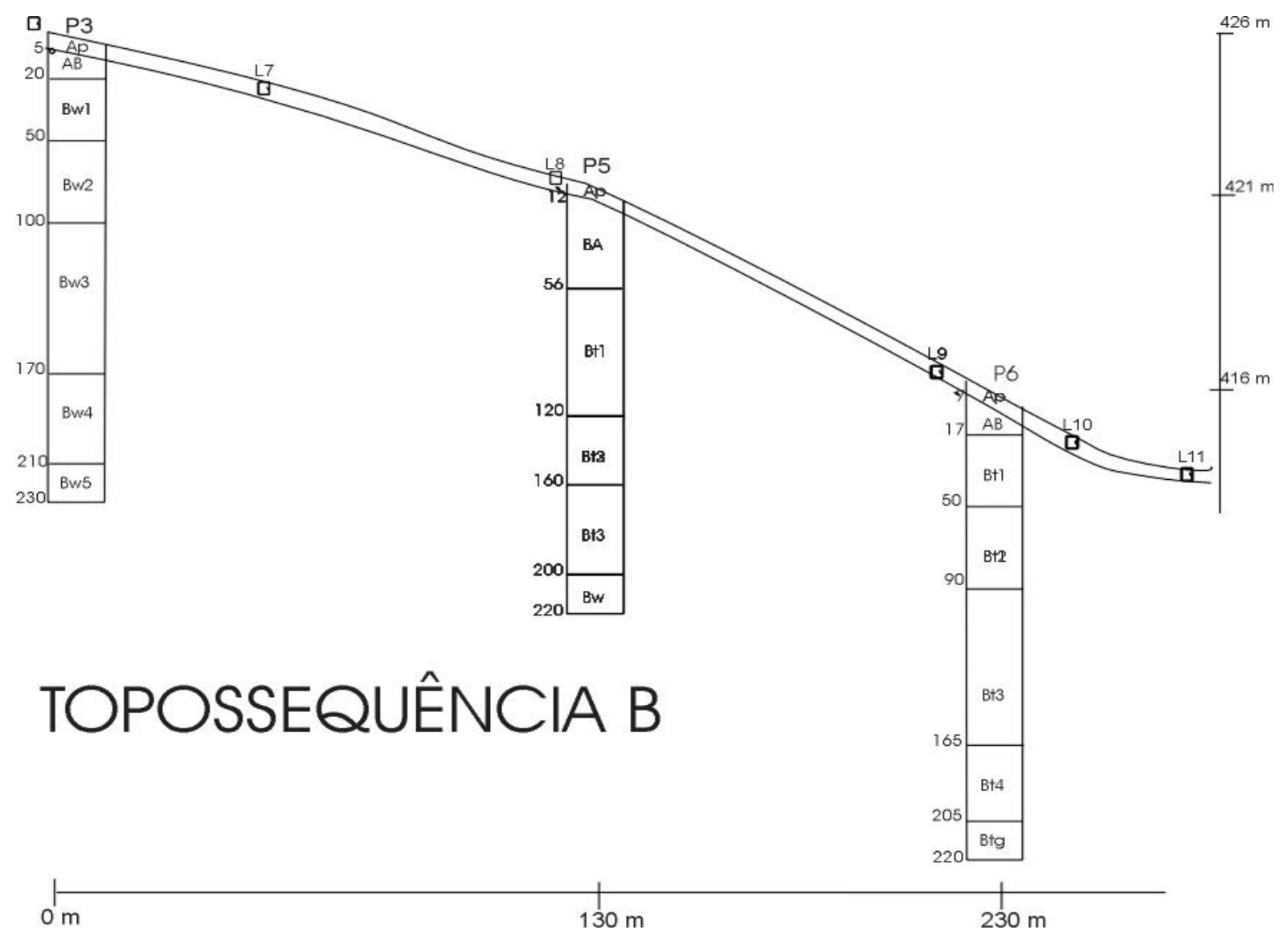

Figura 5 - Topossequência B estudada no município de Lins (SP), apresentando a posição dos perfis P3, P5 e P6, respectivas distribuições dos horizontes e localização dos pontos de tradagens L7, L8, L9, L10 e L11. A profundidade dos perfis está em centímetros. 


\subsection{Características granulométricas dos solos ao longo da vertente}

A distribuição dos tamanhos das partículas mostra o predomínio das frações areia fina e areia muito fina em todos os perfis estudados. Os teores de areia total dos horizontes variam entre $58 \%$ e $79 \%$, conforme observado na Tabela 1.

Os teores de areia são maiores nos horizontes superficiais, porém, não ocorre diminuição regular em profundidade. Os Latossolos (perfis P1 e P3), situados na parte superior da vertente, apresentam a menor variação do teor de areia entre os horizontes.

Os valores do teor de argila mostra que os Latossolos (perfis P1 e P3) apresentam os menores gradientes texturais entre os perfis ao longo das topossequências. Os Argissolos situados no meio da vertente (perfis P5 e P2), apresentam gradiente textural intermediário entre os Latossolos e os Argissolos das porções mais baixas da vertente (perfis P6 e P4). Nestes últimos, ocorre gradiente textural abrupto, onde a razão entre os teores de argila entre os horizontes $\mathrm{A}$ e os horizontes $\mathrm{B}$ é maior do que 2 .

Portanto, do topo para a base da vertente, observa-se aumento do teor de argila nos horizontes subsuperficiais (Figura 6).

Isto torna-se evidente quando compara-se as médias dos teores de argila dos horizontes subsuperficiais entre todos os perfis. Do topo para a base das topossequências, obtém-se os seguintes valores: P1(19,1\%) < P3(20,2\%) < $\mathrm{P} 5(21,1 \%)<\mathrm{P} 2(25,3 \%)<\mathrm{P} 6(25,4 \%)<\mathrm{P} 4(25,5 \%)$.

Verticalmente, os horizontes $B$ imediatamente sotopostos aos horizontes A tem maior conteúdo de argila do que os horizontes da base dos perfis, com exceção do perfil $\mathrm{P} 4$, onde $\mathrm{o}$ incremento de argila ocorre continuamente em profundidade. No perfil P5, os teores nos horizontes subsuperficiais quase não se alteram. 
Tabela 1. Distribuição granulométrica dos horizontes dos solos estudados no município de Lins (SP)

\begin{tabular}{|c|c|c|c|c|c|c|c|}
\hline Horizonte & Profundidade & Ar.grossa & Areia.fina & $\begin{array}{c}\text { Areia muito } \\
\text { fina }\end{array}$ & Areia total & Silte & Argila \\
\hline & $\mathrm{cm}$ & & & $\%$ & & & \\
\hline \multicolumn{8}{|c|}{ PERFIL 1 - LATOSSOLO VERMELHO Distrófico típico } \\
\hline Ap & $0-12$ & 1,69 & 47,13 & 26,04 & 74,87 & 11,41 & 13,72 \\
\hline BA & $12-30$ & 1,59 & 45,76 & 23,08 & 70,43 & 11,23 & 18,35 \\
\hline Bw1 & $30-90$ & 1,94 & 46,66 & 21,19 & 69,79 & 10,22 & 19,97 \\
\hline Bw2 & $90-200$ & 1,27 & 43,35 & 25,61 & 70,23 & 10,66 & 19,11 \\
\hline \multicolumn{8}{|c|}{ PERFIL 3 - LATOSSOLO VERMELHO Distrófico típico } \\
\hline $\begin{array}{c}\text { Ap } \\
\text { AB } \\
\text { Bw1 } \\
\text { Bw2 } \\
\text { Bw3 } \\
\text { Bw4 } \\
\text { Bw5 }\end{array}$ & $\begin{array}{c}0-5 \\
5-20 \\
20-50 \\
50-100 \\
100-170 \\
170-210 \\
210-230\end{array}$ & $\begin{array}{l}2,24 \\
2,17 \\
1,88 \\
1,45 \\
1,38 \\
1,87 \\
1,95\end{array}$ & $\begin{array}{r}47,36 \\
50,34 \\
45,26 \\
45,15 \\
44,45 \\
45,89 \\
45,58\end{array}$ & $\begin{array}{l}18,67 \\
23,70 \\
22,10 \\
23,32 \\
23,49 \\
22,34 \\
22,87\end{array}$ & $\begin{array}{l}68,27 \\
76,21 \\
69,24 \\
69,92 \\
69,32 \\
70,10 \\
70,40\end{array}$ & $\begin{array}{c}19,04 \\
9,07 \\
10,16 \\
9,53 \\
10,28 \\
9,95 \\
9,99\end{array}$ & $\begin{array}{l}12,70 \\
14,73 \\
20,60 \\
20,56 \\
20,41 \\
19,96 \\
19,62\end{array}$ \\
\hline \multicolumn{8}{|c|}{ PERFIL 5 - ARGISSOLO VERMELHO Distrófico latossólico } \\
\hline $\begin{array}{l}\mathrm{Ap} \\
\mathrm{AB} \\
\mathrm{BA} \\
\mathrm{Bt1} \\
\mathrm{Bt2} \\
\mathrm{Bt3} \\
\mathrm{Bw}\end{array}$ & $\begin{array}{c}0-5 \\
5-12 \\
12-56 \\
56-120 \\
120-160 \\
160-200 \\
200+\end{array}$ & $\begin{array}{l}2,21 \\
1,75 \\
1,30 \\
1,00 \\
1,03 \\
0,80 \\
1,29\end{array}$ & $\begin{array}{l}54,09 \\
47,48 \\
39,07 \\
39,45 \\
38,41 \\
36,86 \\
36,98\end{array}$ & $\begin{array}{l}21,19 \\
27,67 \\
25,60 \\
25,45 \\
25,85 \\
27,33 \\
27,00\end{array}$ & $\begin{array}{l}77,49 \\
76,90 \\
65,97 \\
65,90 \\
65,29 \\
64,99 \\
65,27\end{array}$ & $\begin{array}{l}10,20 \\
12,32 \\
13,61 \\
13,02 \\
13,23 \\
12,99 \\
13,75\end{array}$ & $\begin{array}{l}12,31 \\
10,78 \\
20,42 \\
21,08 \\
21,48 \\
22,01 \\
20,98\end{array}$ \\
\hline \multicolumn{8}{|c|}{ PERFIL 2 - ARGISSOLO VERMELHO-AMARELO Distrófico latossólico } \\
\hline $\begin{array}{l}\mathrm{Ap} \\
\mathrm{BA} \\
\mathrm{Bt1} \\
\mathrm{Bt2} \\
\mathrm{Bt3} \\
\mathrm{Btg}\end{array}$ & $\begin{array}{c}0-10 \\
10-35 \\
35-75 \\
75-120 \\
120-210 \\
210-250\end{array}$ & $\begin{array}{l}1,24 \\
1,13 \\
1,41 \\
1,22 \\
1,03 \\
1,25\end{array}$ & $\begin{array}{l}51,22 \\
43,51 \\
41,87 \\
41,31 \\
39,64 \\
40,49\end{array}$ & $\begin{array}{l}23,50 \\
21,11 \\
18,24 \\
20,46 \\
23,34 \\
21,15\end{array}$ & $\begin{array}{l}75,96 \\
65,75 \\
61,52 \\
62,99 \\
64,01 \\
62,89\end{array}$ & $\begin{array}{l}10,56 \\
11,47 \\
10,93 \\
10,55 \\
12,15 \\
11,16\end{array}$ & $\begin{array}{l}13,48 \\
22,78 \\
27,55 \\
26,46 \\
23,84 \\
25,95\end{array}$ \\
\hline \multicolumn{8}{|c|}{ PERFIL 6 - ARGISSOLO VERMELHO Distrófico abrúptico } \\
\hline $\begin{array}{c}\mathrm{A} \\
\mathrm{AB} \\
\mathrm{Bt} 1 \\
\mathrm{~B} 2 \\
\mathrm{~B} 2 \\
\mathrm{Bt} 4 \\
\mathrm{Btg}\end{array}$ & $\begin{array}{c}0-7 \\
7-17 \\
17-50 \\
50-90 \\
90-165 \\
165-205 \\
205-240\end{array}$ & $\begin{array}{l}1,80 \\
1,45 \\
1,41 \\
0,70 \\
0,69 \\
0,72 \\
0,62\end{array}$ & $\begin{array}{l}51,91 \\
54,69 \\
37,32 \\
34,10 \\
41,87 \\
37,04 \\
42,94\end{array}$ & $\begin{array}{l}23,73 \\
22,87 \\
21,82 \\
23,58 \\
22,20 \\
25,45 \\
21,00\end{array}$ & $\begin{array}{l}77,44 \\
79,01 \\
60,55 \\
58,38 \\
64,76 \\
63,21 \\
64,56\end{array}$ & $\begin{array}{l}14,54 \\
12,58 \\
14,16 \\
13,33 \\
11,40 \\
12,53 \\
11,26\end{array}$ & $\begin{array}{l}8,02 \\
8,40 \\
25,29 \\
28,29 \\
23,84 \\
24,26 \\
24,18\end{array}$ \\
\hline \multicolumn{8}{|c|}{ PERFIL4 - ARGISSOLO AMARELO Distrófico abrúptico } \\
\hline A1 & $0-7$ & 2,25 & 45,24 & 21,76 & 69,25 & 20,37 & 10,35 \\
\hline$A B$ & $7-23)$ & 1,31 & 53,38 & 23,36 & 78,05 & 10,93 & 11,00 \\
\hline $\mathrm{Bt} 1$ & $23-57$ & 0,97 & 46,79 & 16,28 & 64,04 & 12,58 & 23,36 \\
\hline Bt2 & $57-94$ & 1,31 & 41,43 & 19,40 & 62,14 & 11,06 & 26,78 \\
\hline Btg & $94-155$ & 1,09 & 41,74 & 18,43 & 61,26 & 12,32 & 26,41 \\
\hline
\end{tabular}



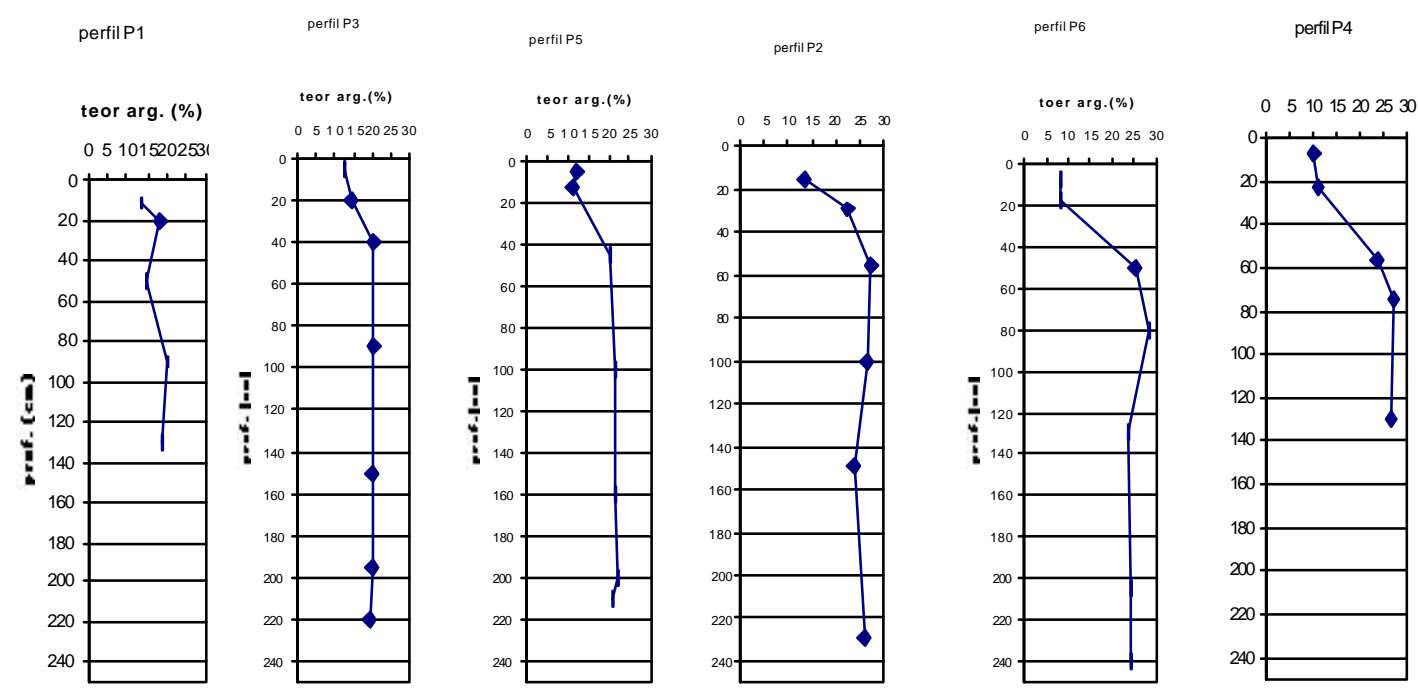

Figura 6 - Gráficos da variação do teor de argila (\%) em profundidade (cm) dos perfis de solo estudados no município de Lins (SP).

Texturalmente, todos horizontes superficiais pertencem á classe areiafranca (grupamento textura arenosa) e os horizontes subsuperficiais á classe franco-argilo-arenosa (grupamento textura média), com exceção dos horizontes latossólicos do perfil $\mathrm{P} 1$ e $\mathrm{Bw}_{4}$ e $\mathrm{Bw}_{5}$ do perfil $\mathrm{P} 3$, que pertencem á classe franco-arenosa (grupamento textura média).

Os valores da análise granulométrica dos perfis de solo estudados, coincidem com os valores obtidos para os sedimentos da Formação Adamantina analisados por Soares et al. (1980) e com os valores obtidos por Moniz \& Carvalho (1973), para os solos arenosos desenvolvidos sobre as Formações Adamantina e Marília, membros superiores do Grupo Bauru.

\subsection{Caracterização do complexo argilo-húmico dos solos estudados}

Os valores dos atributos químicos do complexo argilo-húmico dos horizontes amostrados podem ser observados na Tabela 2. 
Tabela 2. Atributos químicos do complexo argilo-húmico dos solos estudados no município de Lins (SP)

\begin{tabular}{|c|c|c|c|c|c|c|c|c|c|c|c|c|c|c|c|}
\hline \multirow[t]{2}{*}{ Horiz } & \multicolumn{3}{|c|}{$\mathrm{pH}$. } & \multirow{2}{*}{$\begin{array}{c}\text { M.O } \\
g^{C C . k g-1}\end{array}$} & \multirow{2}{*}{$\begin{array}{c}\mathrm{P} \\
\mathrm{mg} \cdot \mathrm{kg}^{-1}\end{array}$} & \multirow[t]{2}{*}{$\mathrm{Na}$} & \multirow[t]{2}{*}{$\mathrm{K}$} & \multirow[t]{2}{*}{$\overline{\mathrm{Ca}}$} & \multirow{2}{*}{\multicolumn{2}{|c|}{$\begin{array}{l}\mathrm{Mg} \mathrm{Al} \\
\text { mmolc .kg }\end{array}$}} & \multirow{2}{*}{${ }_{-1} \mathrm{H}+\mathrm{Al}$} & \multirow[t]{2}{*}{ SB } & \multirow[t]{2}{*}{$\mathrm{T}$} & \multirow[t]{2}{*}{$\mathrm{V}$} & \multirow[t]{2}{*}{$\mathrm{m}$} \\
\hline & $\mathrm{H}_{2} \mathrm{O}$ & $\mathrm{KCl}$ & $\mathrm{CaCl}_{2}$ & & & & & & & & & & & & \\
\hline \multicolumn{16}{|c|}{ P1 LATOSSOLO VERMELHO Distrófico típico } \\
\hline Ap & 4,6 & 4,0 & 4,3 & 20 & 5 & 0,2 & 1,4 & 12 & 7 & 4 & 35 & 20,6 & 55,6 & 37 & 16 \\
\hline BA & 4,6 & 3,8 & 4,0 & 10 & 2 & 0,3 & 0,7 & 6 & 2 & 10 & 30 & 9,0 & 39,0 & 23 & 53 \\
\hline $\mathrm{Bw}_{1}$ & 4,3 & 3,8 & 3,8 & 10 & 2 & 0,2 & 1,1 & 2 & 1 & 13 & 33 & 4,3 & 37,3 & 12 & 75 \\
\hline $\mathrm{Bw}_{2}$ & 4,4 & 4,0 & 3,9 & 5 & 3 & 0,3 & 1,6 & 2 & 1 & 6 & 23 & 4,9 & 27,9 & 18 & 55 \\
\hline \multicolumn{16}{|c|}{ P3 LATOSSOLO VERMELHO Distrófico típico } \\
\hline Ap & 5,4 & 4,6 & 4,9 & 18 & 2 & 0,2 & 1,9 & 10 & 7 & 0 & 34 & 19,1 & 53,1 & 36 & 0 \\
\hline$A B$ & 4,6 & 4,0 & 4,1 & 13 & 3 & 0,2 & 0,9 & 7 & 3 & 7 & 30 & 11,1 & 41,1 & 27 & 39 \\
\hline $\mathrm{Bw}_{1}$ & 4,6 & 4,0 & 4,2 & 10 & 3 & 0,3 & 0,4 & 5 & 5 & 5 & 28 & 10,7 & 38,7 & 28 & 32 \\
\hline $\mathrm{Bw}_{2}$ & 4,3 & 3,8 & 4,0 & 8 & 2 & 0,2 & 1,5 & 1 & 1 & 10 & 28 & 3,7 & 31,7 & 12 & 73 \\
\hline $\mathrm{Bw}_{3}$ & 4,7 & 4,1 & 4,1 & 5 & 2 & 0,3 & 1,9 & 1 & 1 & 8 & 20 & 4,2 & 24,2 & 17 & 66 \\
\hline $\mathrm{Bw}_{4}$ & 4,6 & 4,0 & 4,1 & 5 & 2 & 0,3 & 1,2 & 1 & 1 & 8 & 22 & 3,5 & 25,5 & 14 & 70 \\
\hline $\mathrm{Bw}_{5}$ & 4,5 & 4,0 & 3,9 & 5 & 3 & 0,4 & 0,9 & 1 & 1 & 8 & 20 & 3,3 & 23,3 & 14 & 71 \\
\hline \multicolumn{16}{|c|}{ P5 ARGISSOLO VERMELHO Distrófico latossólico } \\
\hline Ap & 5,0 & 4,3 & 4,4 & 23 & 5 & 0.2 & 2,1 & 11 & 9 & 2 & 30 & 22,3 & 52,3 & 43 & 8 \\
\hline$A B$ & 4,8 & 4,1 & 4,4 & 13 & 3 & 0.2 & 1,0 & 7 & 4 & 2 & 29 & 12,2 & 41,2 & 30 & 14 \\
\hline BA & 4,5 & 3,9 & 4,0 & 8 & 3 & 0.3 & 0,8 & 6 & 2 & 9 & 28 & 9,1 & 37,1 & 25 & 50 \\
\hline $\mathrm{Bt}_{1}$ & 4,5 & 4,0 & 4,1 & 5 & 3 & 0.3 & 1,2 & 21 & 2 & 8 & 27 & 5,5 & 32,5 & 17 & 59 \\
\hline $\mathrm{Bt}_{2}$ & 5,0 & 4,1 & 4,0 & 5 & 2 & 0.3 & 4,2 & 1 & 1 & 9 & 22 & 6,5 & 28,5 & 23 & 58 \\
\hline $\mathrm{Bt}_{3}$ & 5,0 & 4,1 & 4,1 & 5 & 3 & 0.3 & 3,6 & 1 & 1 & 7 & 20 & 5,9 & 25,9 & 23 & 54 \\
\hline Bw & 4,7 & 4,2 & 4,2 & 5 & 2 & 0.3 & 1,9 & 1 & 1 & 9 & 22 & 4,2 & 26,2 & 16 & 68 \\
\hline \multicolumn{16}{|c|}{ P2 ARGISSOLO VERMELHO-AMARELO Distrófico latossólico } \\
\hline Ap & 4,7 & 4,1 & 4,3 & 10 & 2 & 0,3 & 1,7 & 6 & 3 & 3 & 27 & 11,0 & 38,0 & 29 & 21 \\
\hline BA & 4,3 & 3,9 & 4,0 & 10 & 2 & 0,2 & 0,9 & 6 & 1 & 9 & 32 & 8,1 & 40,1 & 20 & 53 \\
\hline $\mathrm{Bt}_{1}$ & 4,6 & 3,9 & 4,1 & 8 & 2 & 0,3 & 0,6 & 5 & 3 & 9 & 33 & 8,9 & 41,9 & 21 & 50 \\
\hline $\mathrm{Bt}_{2}$ & 4,3 & 4,0 & 4,1 & 5 & 2 & 0,3 & 1,0 & 1 & 3 & 9 & 27 & 5,3 & 32,3 & 16 & 63 \\
\hline $\mathrm{Bt}_{3}$ & 4,8 & 4,2 & 4,2 & 5 & 2 & 0,2 & 1,4 & 1 & 3 & 5 & 20 & 5,6 & 25,6 & 22 & 47 \\
\hline Btg & 4,7 & 4,2 & 4,0 & 5 & 2 & 0,2 & 2,2 & 1 & 1 & 10 & 25 & 4,4 & 29,4 & 15 & 69 \\
\hline \multicolumn{16}{|c|}{ P6 ARGISSOLO VERMELHO Distrófico abrúptico } \\
\hline A & 5,6 & 4,8 & 4,8 & 28 & 6 & 0.2 & 2,6 & 13 & 10 & 1 & 27 & 25,8 & 52,8 & 49 & 4 \\
\hline$A B$ & 5,0 & 4,3 & 4,5 & 15 & 3 & 0.2 & 1,8 & 7 & 5 & 2 & 27 & 14,0 & 41,0 & 34 & 13 \\
\hline $\mathrm{Bt}_{1}$ & 4,6 & 4,0 & 2,9 & 13 & 2 & 0.2 & 0,9 & 9 & 3 & 10 & 34 & 13,1 & 47,1 & 28 & 43 \\
\hline $\mathrm{Bt}_{2}$ & 4,5 & 4,1 & 4,1 & 8 & 2 & 0.2 & 0,9 & 4 & 3 & 9 & 29 & 8,1 & 37,1 & 22 & 53 \\
\hline $\mathrm{Bt}_{3}$ & 4,7 & 4,0 & 4,0 & 5 & 2 & 0.2 & 2,4 & 2 & 2 & 9 & 23 & 6,6 & 29,6 & 22 & 58 \\
\hline $\mathrm{Bt}_{4}$ & 4,6 & 3,9 & 4,0 & 5 & 2 & 0.3 & 1,8 & 1 & 3 & 13 & 23 & 6,1 & 29,1 & 21 & 68 \\
\hline Btg & 4,6 & 4,0 & 3,9 & 5 & 3 & 0.3 & 1,6 & 1 & 6 & 12 & 24 & 8,9 & 32,9 & 27 & 67 \\
\hline \multicolumn{16}{|c|}{ P4 ARGISSOLO AMARELO Distrófico abrúptico } \\
\hline$A_{1}$ & 5,4 & 4,7 & 4,9 & 28 & 8 & 0,3 & 5,0 & 22 & 15 & 0 & 40 & 42,3 & 82,3 & 51 & 0 \\
\hline$A B$ & 5,0 & 4,6 & 4,6 & 8 & 2 & 0,3 & 0,4 & 10 & 3 & 1 & 23 & 13,7 & 36,7 & 37 & 7 \\
\hline $\mathrm{Bt}_{1}$ & 4,6 & 4,1 & 4,2 & 10 & 3 & 0,3 & 0,8 & 8 & 3 & 5 & 28 & 12,1 & 40,1 & 30 & 29 \\
\hline $\mathrm{Bt}_{2}$ & 4,5 & 3,9 & 3,9 & 5 & 3 & 0,3 & 1,2 & 3 & 3 & 11 & 25 & 7,5 & 32,5 & 23 & 59 \\
\hline $\mathrm{Btg}$ & 4,6 & 4,1 & 4,2 & 8 & 3 & 0,2 & 1,5 & 2 & 5 & 7 & 24 & 8,7 & 32,7 & 27 & 45 \\
\hline
\end{tabular}




\section{$\mathrm{pH}$, teor de alumínio trocável e saturação por alumínio (m\%)}

Os valores de $\mathrm{pH}$ em $\mathrm{H}_{2} \mathrm{O}, \mathrm{CaCl}_{2}$ e $\mathrm{KCl}$, tiveram a mesma variação tanto para os Latossolos quanto para os Argissolos, ocorrendo ligeira diminuição em profundidade.

Os resultados de $\mathrm{pH}$ medido em água forneceram resultados que variam entre 4,3 e 5,3, qualificando os solos como fortemente ácidos (EMBRAPA, 1999).

Os horizontes superficiais dos perfis $\mathrm{P} 3, \mathrm{P} 4$ e $\mathrm{P} 6$, apresentam $\mathrm{pH}$ em $\mathrm{H}_{2} \mathrm{O}$ entre 5,4 e 5,6, provavelmente devido à resquícios de calagens feitas anteriormente no terreno. Nestes horizontes, o teor de alumínio trocável é nulo. Nos outros horizontes, apesar dos teores de Al trocável serem baixos, o Al ocupa uma grande proporção da capacidade de troca catiônica total (T) do solo. Os valores de saturação por $\mathrm{Al}(\mathrm{m} \%)$ variam entre 39\% e 73\%, atingindo níveis tóxicos aos solos. Este atributo permite classificá-los como álicos quando $\mathrm{m} \% \geq$ $50 \%$ (EMBRAPA,1999). A presença de Al no complexo de troca é uma das características das coberturas de alteração ferralíticas, como descrito por Melfi \& Pedro (1977).

Os valores de $\mathrm{pH}$ obtidos em solução de $\mathrm{KCl}$ são sempre menores que os valores obtidos em água destilada e $\mathrm{CaCl}_{2}$, portanto, os valores de $\Delta \mathrm{pH}$ $\left(\mathrm{pH}_{\mathrm{KCl}}-\mathrm{pH}_{\mathrm{H} 2 \mathrm{O}}\right)$ são negativos, indicando que os solos tem carga líquida negativa (Mekaru \& Uehara, 1972).

Em solos de cargas variáveis, solos com carga líquida negativa indicam predomínio de argilominerais silicatados sobre de hidróxidos de $\mathrm{Fe}$ e $\mathrm{Al}$, pois estes últimos são os principais receptores de prótons nestes tipos de solos (Yu, 1997).

\section{Matéria orgânica}

Os teores de matéria orgânica nos horizontes superficiais variam entre 10 e $28 \mathrm{gC} \mathrm{kg}^{-1}$. Os valores mais altos são atingidos nos Argissolos localizados nas porções baixas da vertente (perfis P6 e P4), onde estes horizontes 
permanecem saturados por mais tempo, diminuindo a oxigenação e dificultando a mineralização da matéria orgânica.

Bases trocáveis, soma de bases (SB), capacidade de troca de cátions total (T) e saturação por bases (V\%)

Os teores de $\mathrm{Na}$ são baixos, entre 0,2 e 0,4 mmolc. $\mathrm{kg}^{-1}$. Seu comportamento pode ser considerado constante tanto em profundidade nos perfis, quanto ao longo da vertente.

$\mathrm{Ca}$ e $\mathrm{Mg}$ apresentam diminuição em profundidade, tanto nos Latossolos quanto nos Argissolos. Para os Argissolos, seria comum ocorrer aumento nos teores destes cátions em profundidade (Brasil, 1960; Carvalho,1976).

$A$ variação dos teores de $\mathrm{K}$ apresentam comportamento semelhante nos perfis $\mathrm{P} 1, \mathrm{P} 2$ e $\mathrm{P} 4$, onde ocorre diminuição do horizonte superficial para o horizonte de transição e à partir daí ocorre aumento em profundidade. Nos outros perfis, também ocorre diminuição até os horizontes de transição, porém, a partir daí, ocorre aumento brusco, para então diminuir em profundidade.

A SB apresenta valores mais altos nos horizontes superficiais, atingindo o máximo no horizonte A do perfil P4 (42,3 mmolc. $\left.\mathrm{kg}^{-1}\right)$, acompanhando a variação da matéria orgânica, devido á sua alta capacidade de retenção de cátions. Porém, com exceção deste horizonte, os valores são baixos, variando de 11,0 a 25,8 mmolc. $\mathrm{kg}^{-1}$ nos horizontes superficiais e 3,3 a 13,1 nos subsuperficiais.

Tanto os Latossolos quanto os Argissolos apresentam valores baixos de V\%, sendo classificados como distróficos, porém os Argissolos apresentam valores ligeiramente maiores nos horizontes subsuperficiais.

Os valores de T não apresentam variações significativas dos Latossolos para os Argissolos, com exceção do horizonte $A$ do perfil situado na base da topossequência (perfil P4), que atinge o valor de 82,3 mmolc. $\mathrm{kg}^{-1}$, devido à maior concentração de matéria orgânica. Nos horizontes superficiais, os valores de $T$ variam entre 38,0 e 55,6 mmolc. $\mathrm{kg}^{-1}$ e nos horizontes subsuperficiais variam entre 23,3 e 47,1 mmolc. $\mathrm{kg}^{-1}$. 


\subsection{Composição química dos solos estudados}

Os resultados das análises químicas dos elementos maiores e traços, que constituem os solos estudados, podem ser observados nas Tabelas 3 e 4 .

Entre os elementos maiores analisados (Tabela 3 ), verificou-se alta predominância de $\mathrm{SiO}_{2}$ (80 a 90\%) em todos os horizontes dos solos estudados. Os maiores valores de $\mathrm{SiO} 2$ ocorrem nos horizontes superficiais, sendo inversamente proporcionais ao teor de argila e diretamente proporcionais ao teor de areia total mais silte dos perfis analisados, indicando forte presença de quartzo nestas duas frações granulométricas.

Os valores de $\mathrm{Al}_{2} \mathrm{O}_{3}$ variam de 4,0 a $7,3 \%$ nos Latossolos e de 3,6 a 9,6\% Argissolos. Verticalmente, ocorre aumento da concentração de $\mathrm{Al}_{2} \mathrm{O}_{3}$ dos horizontes superficiais para os subsuperficiais. A variação dos valores deste óxido também está relacionada àvariação do teor de argila, tanto do topo para a base das topossequências, quanto em profundidade nos perfis.

$A$ variação de $\mathrm{Fe}_{2} \mathrm{O}_{3}$ nos perfis dos Latossolos não difere muito dos perfis dos Argissolos. Verticalmente, ocorre aumento do teor de $\mathrm{Fe}_{2} \mathrm{O}_{3}$ dos horizontes superficiais para os subsuperficiais.

Os teores de $\mathrm{TiO}_{2}$ não apresentam variação significativa em relação à posição dos perfis nas topossequências. Verticalmente, ocorre um ligeiro aumento do teor em profundidade. Os valores de titânio encontrados devem-se á presença de ilmenita, mineral muito estável, herdado das rochas de origem (Coimbra, 1976), podendo também ser encontrado nas estruturas dos óxidos de ferro.

Os teores de $\mathrm{K}_{2} \mathrm{O}$ são ligeiramente menores nos Latossolos do que Argissolos e sua variação entre os horizontes dos solos é pouco significativa. $O$ perfil $\mathrm{P} 6$, apresenta os horizontes com as maiores concentrações de $\mathrm{K}_{2} \mathrm{O}$ ao longo das topossequências.

Os outros óxidos $\left(\mathrm{MgO}, \mathrm{CaO}, \mathrm{MnO}\right.$ e $\left.\mathrm{P}_{2} \mathrm{O}_{5}\right)$ ocorrem em quantidades muito pequenas. 
Através da análise de teores totais dos elementos-traço (Tabela 4), observa-se a presença de alguns elementos essenciais para animais e plantas, como $\mathrm{B}, \mathrm{Co}, \mathrm{Cr}, \mathrm{Cu}, \mathrm{Li}, \mathrm{Ni}, \mathrm{V}$ e $\mathrm{Zn}$ e outros que podem ser tóxicos se disponibilizados, como $\mathrm{Ba}, \mathrm{Pb}$ e $\mathrm{Sr}$. De modo geral, os elementos-traço encontram-se dentro do background esperado para a crosta terrestre (Mason, 1971). 
Tabela 3. Composição química dos solos estudados no município de Lins (SP). Óxidos dos elementos maiores expressos em \% peso.

\begin{tabular}{|c|c|c|c|c|c|c|c|c|c|c|c|}
\hline Horizontes & $\mathrm{SiO}_{2}$ & $\mathrm{Al}_{2} \mathrm{O}_{3}$ & $\mathrm{Fe}_{2} \mathrm{O}_{3}$ & $\mathrm{TiO}_{2}$ & $\mathrm{~K}_{2} \mathrm{O}$ & $\mathrm{MgO}$ & $\mathrm{CaO}$ & MnO & $\mathrm{P}_{2} \mathrm{O}_{5}$ & $\mathrm{Na}_{2} \mathrm{O}$ & $\begin{array}{c}\text { Perda ao } \\
\text { fogo }\end{array}$ \\
\hline \multicolumn{12}{|c|}{ P1 LATOSSOLO VERMELHO Distrófico típico } \\
\hline Ap & 86,50 & 5,30 & 2,10 & 0,94 & 0,60 & 0,20 & 0,05 & 0,04 & 0,026 & $<0,10$ & 3,92 \\
\hline BA & 85,10 & 7,30 & 2,40 & 0,98 & 0,42 & 0,18 & 0,10 & 0,04 & 0,026 & $<0,10$ & 3,48 \\
\hline $\mathrm{Bw}_{1}$ & 85,60 & 6,90 & 2,60 & 1,10 & 0,17 & 0,12 & 0,04 & 0,04 & 0,029 & $<0,10$ & 3,33 \\
\hline $\mathrm{Bw}_{2}$ & 85,80 & 6,80 & 2,60 & 1,10 & 0,17 & 0,15 & 0,04 & 0,04 & 0,026 & $<0,10$ & 2,99 \\
\hline \multicolumn{12}{|c|}{ P3 LATOSSOLO VERMELHO Distrófico típico } \\
\hline Ap & 89,20 & 4,00 & 1,70 & 0,75 & 0,21 & $<0.10$ & 0,04 & 0,03 & 0,033 & $<0,10$ & 3,17 \\
\hline$A B$ & 87,30 & 5,30 & 2,20 & 0,90 & 0,22 & 0,16 & 0,03 & 0,04 & 0,029 & $<0,10$ & 3,38 \\
\hline $\mathrm{Bw}_{1}$ & 83,70 & 7,30 & 2,70 & 1,10 & 0,23 & 0,17 & 0,03 & 0,03 & 0,013 & $<0,10$ & 3,77 \\
\hline $\mathrm{Bw}_{2}$ & 83,70 & 7,10 & 2,70 & 1,10 & 0,25 & 0,16 & 0,04 & 0,04 & 0,03 & $<0,10$ & 3,51 \\
\hline $\mathrm{Bw}_{3}$ & 84,50 & 7,30 & 2,70 & 1,10 & 0,24 & 0,17 & 0,02 & 0,04 & 0,028 & $<0,10$ & 3,18 \\
\hline $\mathrm{Bw}_{4}$ & 85,0 & 7,20 & 2,70 & 1,10 & 0,23 & 0,22 & 0,03 & 0,04 & $<0.01$ & $<0,10$ & 3,30 \\
\hline $\mathrm{Bw}_{5}$ & 85,20 & 7,30 & 2,70 & 1,10 & 0,23 & 0,17 & 0,02 & 0,04 & 0,029 & $<0,10$ & 3,08 \\
\hline \multicolumn{12}{|c|}{ P5 ARGISSOLO VERMELHO Distrófico latossólico } \\
\hline Ap & 88,80 & 4,60 & 2,10 & 0,98 & 0,27 & 0,13 & 0,03 & 0,04 & 0,036 & $<0,10$ & 3,55 \\
\hline$A B$ & 89,0 & 4,40 & 2,10 & 0,97 & 0,27 & 0,13 & 0,03 & 0,04 & 0,029 & $<0,10$ & 3,29 \\
\hline $\mathrm{BA}$ & 83,60 & 7,30 & 3,10 & 1,30 & 0,33 & 0,18 & 0,04 & 0,04 & 0,047 & $<0,10$ & 3,85 \\
\hline $\mathrm{Bt}_{1}$ & 83,50 & 7,70 & 3,20 & 1,30 & 0,45 & 0,26 & 0,05 & 0,05 & 0,045 & 0,16 & 3,47 \\
\hline $\mathrm{Bt}_{2}$ & 83,20 & 7,70 & 3,20 & 1,30 & 0,36 & 0,15 & 0,03 & 0,04 & 0,045 & $<0,10$ & 3,23 \\
\hline $\mathrm{Bt}_{3}$ & 83,90 & 7,80 & 3,30 & 1,40 & 0,36 & 0,21 & 0,02 & 0,04 & 0,036 & $<0,10$ & 3,34 \\
\hline Bw & 83,50 & 7,80 & 3,20 & 1,40 & 0,29 & 0,25 & 0,03 & 0,05 & 0,036 & $<0,10$ & 3,31 \\
\hline \multicolumn{12}{|c|}{ P2 ARGISSOLO VERMELHO-AMARELO Distrófico latossólico } \\
\hline Ap & 89,0 & 4,90 & 2,0 & 0,98 & 0,33 & 0,17 & 0,07 & 0,03 & 0,029 & $<0,10$ & 3,0 \\
\hline $\mathrm{BA}$ & 82,70 & 8,10 & 2,80 & 1,20 & 0,36 & 0,22 & 0,07 & 0,04 & 0,052 & $<0,10$ & 4,37 \\
\hline $\mathrm{Bt}_{1}$ & 80,60 & 9,20 & 3,10 & 1,30 & 0,35 & 0,20 & 0,06 & 0,03 & 0,048 & $<0,10$ & 4,72 \\
\hline $\mathrm{Bt}_{2}$ & 81,50 & 9,20 & 3,0 & 1,30 & 0,36 & 0,19 & 0,03 & 0,03 & 0,027 & $<0,10$ & 4,10 \\
\hline $\mathrm{Bt}_{3}$ & 81,70 & 9,0 & 3,30 & 1,20 & 0,33 & 0,18 & 0,04 & 0,03 & 0,045 & $<0,10$ & 3,91 \\
\hline Btg & 82,70 & 9,10 & 3,0 & 1,20 & 0,42 & 0,25 & 0,03 & 0,04 & 0,023 & $<0,10$ & 3,82 \\
\hline \multicolumn{12}{|c|}{ P6 ARGISSOLO VERMELHO Distrófico abrúptico } \\
\hline$A$ & 88,60 & 3,90 & 1,60 & 0,95 & 0,51 & 0,19 & 0,06 & 0,04 & 0,022 & $<0,10$ & 4,02 \\
\hline$A B$ & 89,60 & 3,60 & 1,60 & 0,92 & 0,53 & 0,16 & 0,03 & 0,03 & 0,026 & $<0,10$ & 2,92 \\
\hline $\mathrm{Bt}_{1}$ & 80,0 & 9,50 & 3,20 & 1,40 & 0,56 & 0,20 & 0,03 & 0,04 & 0,03 & $<0,10$ & 4,81 \\
\hline $\mathrm{Bt}_{2}$ & 81,30 & 9,50 & 3,0 & 1,20 & 0,47 & 0,25 & 0,02 & 0,03 & 0,035 & $<0,10$ & 4,37 \\
\hline $\mathrm{Bt}_{3}$ & 82,60 & 8,60 & 2,90 & 1,30 & 0,53 & 0,19 & $<0.01$ & 0,04 & 0,015 & $<0,10$ & 3,62 \\
\hline $\mathrm{Bt}_{4}$ & 83,50 & 8,30 & 2,90 & 1,30 & 0,63 & 0,20 & $<0.01$ & 0,03 & 0,016 & $<0,10$ & 3,33 \\
\hline Btg & 81,70 & 8,50 & 3,10 & 1,20 & 0,76 & 0,25 & 0,01 & 0,05 & 0,025 & $<0,10$ & 3,45 \\
\hline \multicolumn{12}{|c|}{ P4 ARGISSOLO AMARELO Distrófico abrúptico } \\
\hline$A_{1}$ & 84,10 & 5,50 & 2,10 & 0,91 & 0,32 & 0,17 & 0,10 & 0,04 & 0,059 & $<0,10$ & 5,80 \\
\hline$A B$ & 90,0 & 4,40 & 1,80 & 0,85 & 0,42 & 0,16 & 0,04 & 0,04 & 0,021 & $<0,10$ & 2,41 \\
\hline $\mathrm{Bt}_{1}$ & 82,40 & 8,40 & 2,70 & 1,0 & 0,45 & 0,24 & 0,06 & 0,03 & 0,061 & $<0,10$ & 4,17 \\
\hline $\mathrm{Bt}_{2}$ & 80,10 & 9,60 & 2,90 & 1,10 & 0,47 & 0,25 & 0,04 & 0,03 & 0,041 & $<0,10$ & 4,38 \\
\hline Btg & 81,70 & 9,60 & 3,0 & 1,20 & 0,53 & 0,28 & 0,04 & 0,03 & 0,053 & $<0,10$ & 4,12 \\
\hline
\end{tabular}


Tabela 4. Composição química dos solos estudados no município de Lins (SP). Elementos-traço expressos em ppm.

\begin{tabular}{|c|c|c|c|c|c|c|c|}
\hline Horizontes & $\mathrm{Ba}$ & $\mathrm{Zr}$ & $\mathrm{Cr}$ & $\mathrm{B}$ & $\mathrm{Pb}$ & $\mathrm{V}$ & $\mathrm{Sr}$ \\
\hline \multicolumn{8}{|c|}{ P1 LATOSSOLO VERMELHO Distrófico típico } \\
\hline Ap & 127 & 93 & 66 & 37 & 35 & 35 & 17 \\
\hline BA & 106 & 107 & 77 & 54 & 41 & 41 & 14 \\
\hline $\mathrm{Bw} \mathrm{w}_{1}$ & 47 & 103 & 76 & 57 & 41 & 48 & 7,5 \\
\hline $\mathrm{Bw}_{2}$ & 50 & 112 & 88 & 61 & 44 & 53 & 7,8 \\
\hline \multicolumn{8}{|c|}{ P3 LATOSSOLO VERMELHO Distrófico típico } \\
\hline Ap & 75 & 75 & 59 & 22 & 24 & 35 & 13 \\
\hline$A B$ & 81 & 102 & 74 & 31 & 35 & 42 & 13 \\
\hline$B w_{1}$ & 79 & 112 & 84 & 109 & 43 & 50 & 15 \\
\hline $\mathrm{Bw}_{2}$ & 82 & 117 & 91 & 105 & 42 & 52 & 14 \\
\hline $\mathrm{Bw}_{3}$ & 80 & 113 & 85 & 86 & 42 & 52 & 13 \\
\hline $\mathrm{Bw}_{4}$ & 78 & 122 & 88 & 76 & 43 & 52 & 12 \\
\hline $\mathrm{Bw}_{5}$ & 79 & 119 & 91 & 75 & 43 & 51 & 12 \\
\hline \multicolumn{8}{|c|}{ P5 ARGISSOLO VERMELHO Distrófico latossólico } \\
\hline$A p$ & 106 & 98 & 86 & 51 & 28 & 40 & 18 \\
\hline$A B$ & 112 & 105 & 89 & 60 & 30 & 42 & 19 \\
\hline BA & 149 & 144 & 110 & 131 & 49 & 57 & 27 \\
\hline $\mathrm{Bt}_{1}$ & 153 & 145 & 107 & 144 & 49 & 59 & 26 \\
\hline $\mathrm{Bt}_{2}$ & 237 & 143 & 116 & 145 & 48 & 59 & 26 \\
\hline $\mathrm{Bt}_{3}$ & 161 & 150 & 119 & 150 & 54 & 63 & 26 \\
\hline Bw & 139 & 143 & 118 & 119 & 47 & 59 & 23 \\
\hline \multicolumn{8}{|c|}{ P2 ARGISSOLO VERMELHO-AMARELO Distrófico latossólico } \\
\hline$A p$ & 109 & 104 & 86 & 51 & 32 & 43 & 18 \\
\hline BA & 135 & 133 & 99 & 94 & 50 & 58 & 24 \\
\hline $\mathrm{Bt}_{1}$ & 130 & 140 & 99 & 105 & 57 & 62 & 24 \\
\hline $\mathrm{Bt}_{2}$ & 131 & 139 & 105 & 110 & 54 & 61 & 23 \\
\hline $\mathrm{Bt}_{3}$ & 127 & 145 & 115 & 108 & 56 & 67 & 22 \\
\hline $\mathrm{Btg}$ & 145 & 138 & 105 & 68 & 55 & 62 & 24 \\
\hline \multicolumn{8}{|c|}{ P6 ARGISSOLO VERMELHO Distrófico abrúptico } \\
\hline A & 157 & 114 & 83 & 22 & 29 & 38 & 23 \\
\hline$A B$ & 148 & 99 & 79 & $<10$ & 29 & 38 & 20 \\
\hline $\mathrm{Bt}_{1}$ & 182 & 171 & 129 & 174 & 60 & 66 & 29 \\
\hline $\mathrm{Bt}_{2}$ & 156 & 153 & 121 & 130 & 60 & 62 & 25 \\
\hline $\mathrm{Bt}_{3}$ & 154 & 147 & 123 & 144 & 52 & 60 & 22 \\
\hline $\mathrm{Bt}_{4}$ & 180 & 146 & 112 & 115 & 52 & 57 & 24 \\
\hline $\mathrm{Btg}$ & 209 & 142 & 106 & 131 & 52 & 55 & 26 \\
\hline \multicolumn{8}{|c|}{ P4 ARGISSOLO AMARELO Distrófico abrúptico } \\
\hline$A_{1}$ & 119 & 105 & 72 & 59 & 36 & 41 & 23 \\
\hline$A B$ & 148 & 104 & 72 & 45 & 32 & 39 & 24 \\
\hline $\mathrm{Bt}_{1}$ & 153 & 119 & 86 & 77 & 50 & 52 & 26 \\
\hline $\mathrm{Bt}_{2}$ & 157 & 129 & 96 & 127 & 52 & 59 & 26 \\
\hline $\mathrm{Btg}$ & 161 & 132 & 100 & 79 & 54 & 55 & 26 \\
\hline
\end{tabular}


Tabela 4. Composição química dos solos estudados no município de Lins (SP). Elementos-traço expressos em ppm.

\begin{tabular}{|c|c|c|c|c|c|c|c|}
\hline Horizontes & $\mathrm{Zn}$ & Co & $\mathrm{Cu}$ & $\mathrm{Ni}$ & $\bar{Y}$ & Sc & $\mathrm{Li}$ \\
\hline \multicolumn{8}{|c|}{ P1 LATOSSOLO VERMELHO Distrófico típico } \\
\hline Ap & 16 & 11 & 11 & 8,7 & 6,4 & 4,8 & 3,5 \\
\hline BA & 16 & 13 & 14 & 12 & 7,9 & 6 & 4,2 \\
\hline $\mathrm{Bw}_{1}$ & 16 & 13 & 14 & 12 & 7,2 & 6,2 & 4,5 \\
\hline $\mathrm{Bw}_{2}$ & 17 & 14 & 15 & 13 & 8,1 & 6,8 & 4,7 \\
\hline \multicolumn{8}{|c|}{ P3 LATOSSOLO VERMELHO Distrófico típico } \\
\hline Ap & 13 & 10 & 10 & 8,4 & 5,2 & 3,9 & 3,6 \\
\hline$A B$ & 15 & 12 & 13 & 12 & 6,6 & $<3.0$ & 4,2 \\
\hline $\mathrm{Bw}_{1}$ & 18 & 14 & 15 & 15 & 8,6 & 4,2 & 4,9 \\
\hline $\mathrm{Bw}_{2}$ & 21 & 15 & 15 & 15 & 8,6 & 3,6 & 5 \\
\hline $\mathrm{Bw}_{3}$ & 18 & 14 & 15 & 14 & 8,2 & 4,9 & 4,9 \\
\hline $\mathrm{Bw}_{4}$ & 19 & 14 & 16 & 14 & 8,3 & 3,5 & 4,9 \\
\hline $\mathrm{Bw}_{5}$ & 18 & 15 & 16 & 15 & 8 & 7,1 & 4,9 \\
\hline \multicolumn{8}{|c|}{ P5 ARGISSOLO VERMELHO Distrófico latossólico } \\
\hline Ap & 18 & 12 & 13 & 11 & 6,7 & 5,1 & 4 \\
\hline$A B$ & 16 & 13 & 13 & 11 & 7 & 4,3 & 4,1 \\
\hline BA & 26 & 17 & 21 & 18 & 12 & 4,2 & 5,6 \\
\hline $\mathrm{Bt}_{1}$ & 22 & 18 & 20 & 19 & 11 & 3,3 & 6 \\
\hline $\mathrm{Bt}_{2}$ & 22 & 18 & 20 & 18 & 11 & 5,2 & 6 \\
\hline $\mathrm{Bt}_{3}$ & 23 & 19 & 21 & 19 & 12 & 8,1 & 6,4 \\
\hline $\mathrm{Bw}$ & 20 & 18 & 19 & 18 & 11 & 7,3 & 5,6 \\
\hline \multicolumn{8}{|c|}{ P2 ARGISSOLO VERMELHO-AMARELO Distrófico latossólico } \\
\hline Ap & 14 & 12 & 13 & 10 & 7,1 & 4,3 & 5,1 \\
\hline BA & 20 & 16 & 19 & 18 & 10 & 7,7 & 7,2 \\
\hline $\mathrm{Bt}_{1}$ & 23 & 17 & 20 & 20 & 13 & 9,4 & 8 \\
\hline $\mathrm{Bt}_{2}$ & 22 & 17 & 20 & 20 & 11 & 8,3 & 7,7 \\
\hline $\mathrm{Bt}_{3}$ & 23 & 18 & 21 & 20 & 11 & 7,1 & 8 \\
\hline $\mathrm{Btg}$ & 20 & 16 & 20 & 19 & 11 & 6,5 & 7,9 \\
\hline \multicolumn{8}{|c|}{ P6 ARGISSOLO VERMELHO Distrófico abrúptico } \\
\hline A & 16 & 12 & 13 & 8,7 & 6,6 & 4,2 & 4,4 \\
\hline$A B$ & 13 & 12 & 12 & 7,8 & 6,4 & 3,5 & 4,2 \\
\hline $\mathrm{Bt}_{1}$ & 23 & 19 & 23 & 22 & 14 & 10 & 9,1 \\
\hline $\mathrm{Bt}_{2}$ & 22 & 18 & 22 & 22 & 15 & 11 & 8,8 \\
\hline $\mathrm{Bt}_{3}$ & 21 & 18 & 20 & 19 & 12 & 12 & 8,2 \\
\hline $\mathrm{Bt}_{4}$ & 18 & 17 & 20 & 18 & 12 & 13 & 8,2 \\
\hline $\mathrm{Btg}$ & 19 & 16 & 19 & 16 & 12 & 15 & 8,2 \\
\hline \multicolumn{8}{|c|}{ P4 ARGISSOLO AMARELO Distrófico abrúptico } \\
\hline$A_{1}$ & 19 & 12 & 14 & 9,5 & 9,1 & 4,8 & 4,2 \\
\hline$A B$ & 14 & 12 & 12 & 8,5 & 8,4 & 5,1 & 4,4 \\
\hline $\mathrm{Bt}_{1}$ & 22 & 14 & 18 & 16 & 11 & 7,7 & 6,3 \\
\hline $\mathrm{Bt}_{2}$ & 23 & 16 & 21 & 18 & 14 & 8,5 & 7,3 \\
\hline Btg & 22 & 16 & 19 & 16 & 13 & 8,5 & 6,8 \\
\hline
\end{tabular}




\subsection{Mineralogia}

A caracterização mineralógica dos solos estudados ao longo das topossequências, foi realizada para as frações granulométricas areia muito fina e argila.

\subsubsection{Mineralogia da fração argila}

Os difratogramas, obtidos da fração argila dos horizontes dos solos analisados, encontram-se nas Figuras 7 a 12.

A mineralogia encontrada nos perfis é simples, representada pela caolinita, ilita, hematita, magnetita e/ou maghemita.

A caolinita foi identificada em todos os horizontes dos perfis analisados,

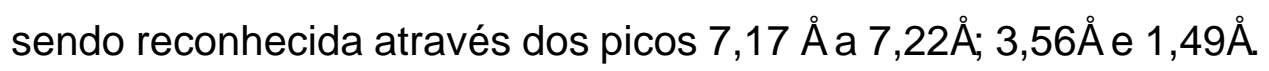

A ilita foi identificada nos perfis P1, P5, P4 e P6 (Figuras 7, 11, 10 e 12, respectivamente). Seus picos característicos $3,34 \AA$ e $10,0 \AA$ mostraram-se pouco intensos, o que significa sua presença em baixas concentrações.

A hematita, magnetita e/ou maghemita foram identificadas em todos os horizontes dos perfis analisados. Os difratogramas obtidos das amostras

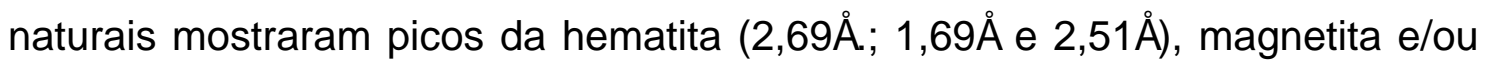
maghemita $(2,53 \AA ̊ ; 1,49 \AA$ e $2,97 \AA ̊)$, que desapareceram após a deferrificação, confirmando a presença destes óxidos de ferro.

A mineralogia, predominantemente, caolinítica, com pequena quantidade de ilita e ausência de gibbsita, é comum nos solos desenvolvidos sobre os sedimentos arenosos do Grupo Baurú (Moniz \& Carvalho, 1973; Carvalho, 1976). 


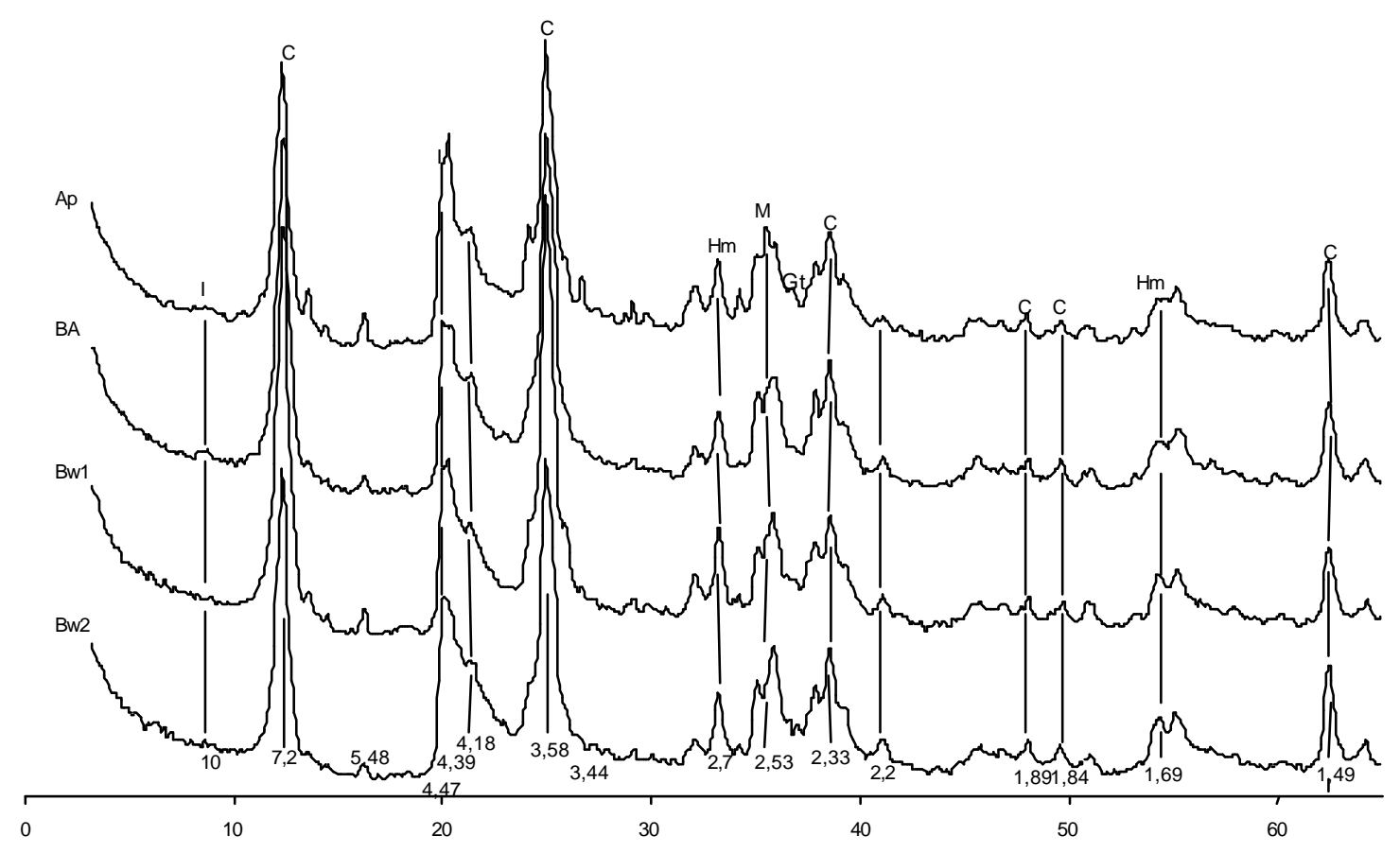

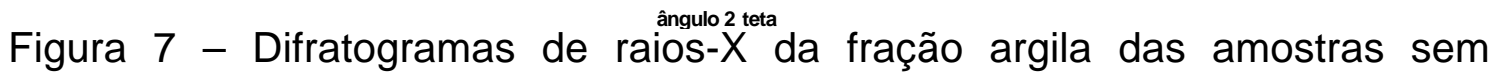
tratamento dos horizontes do perfil P1. Estão assinaladas, abaixo dos picos, as respectivas distâncias interplanares, em Å. C- caolinita; Hm- hematita; Mmagnetita e/ou maghemita.

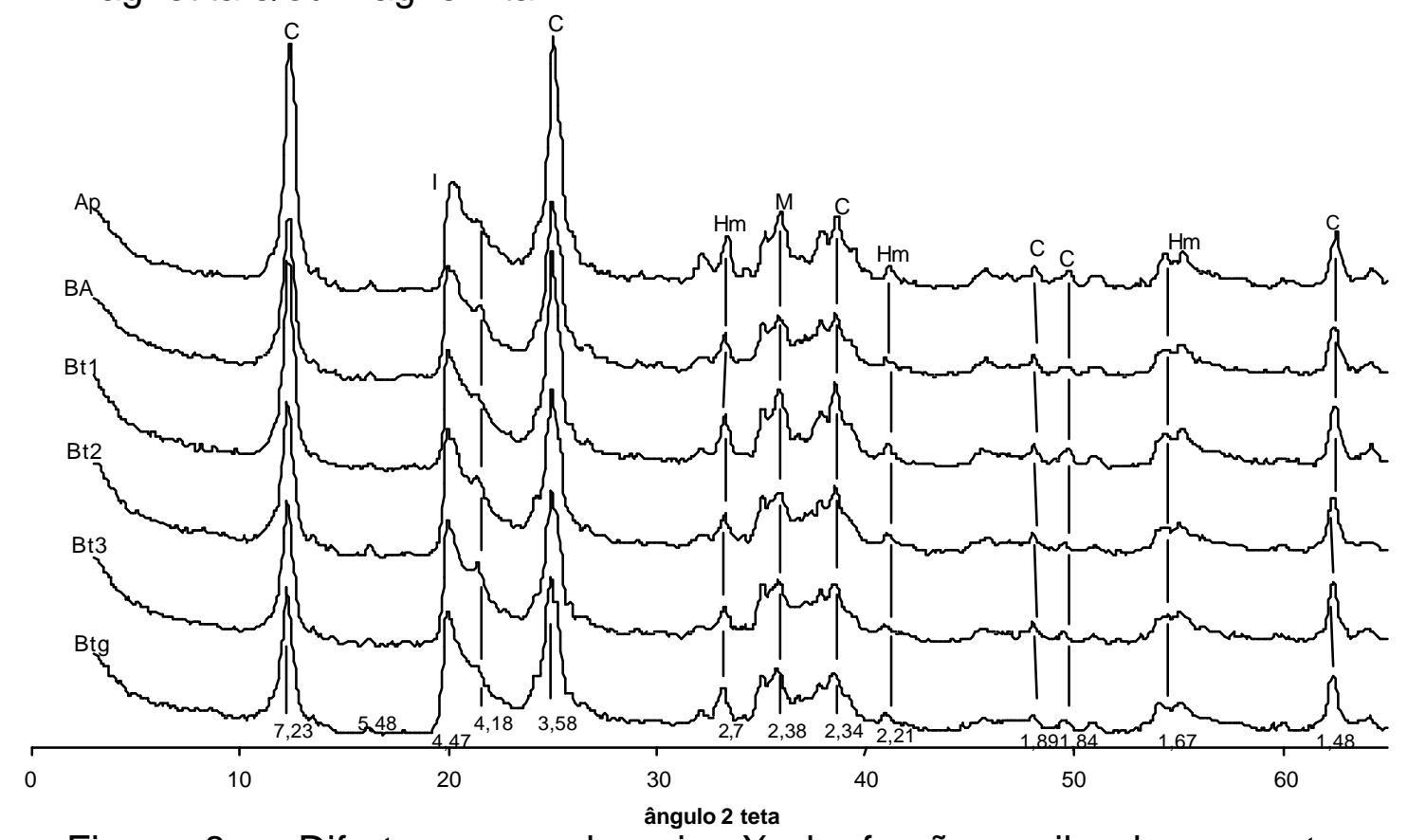

Figura 8 - Difratogramas de raios-X da fração argila das amostras sem tratamento dos horizontes do perfil P2. Estão assinaladas, abaixo dos picos, as respectivas distâncias interplanares, em $\AA$. C- caolinita; Hm- hematita; Mmagnetita e/ou maghemita. 


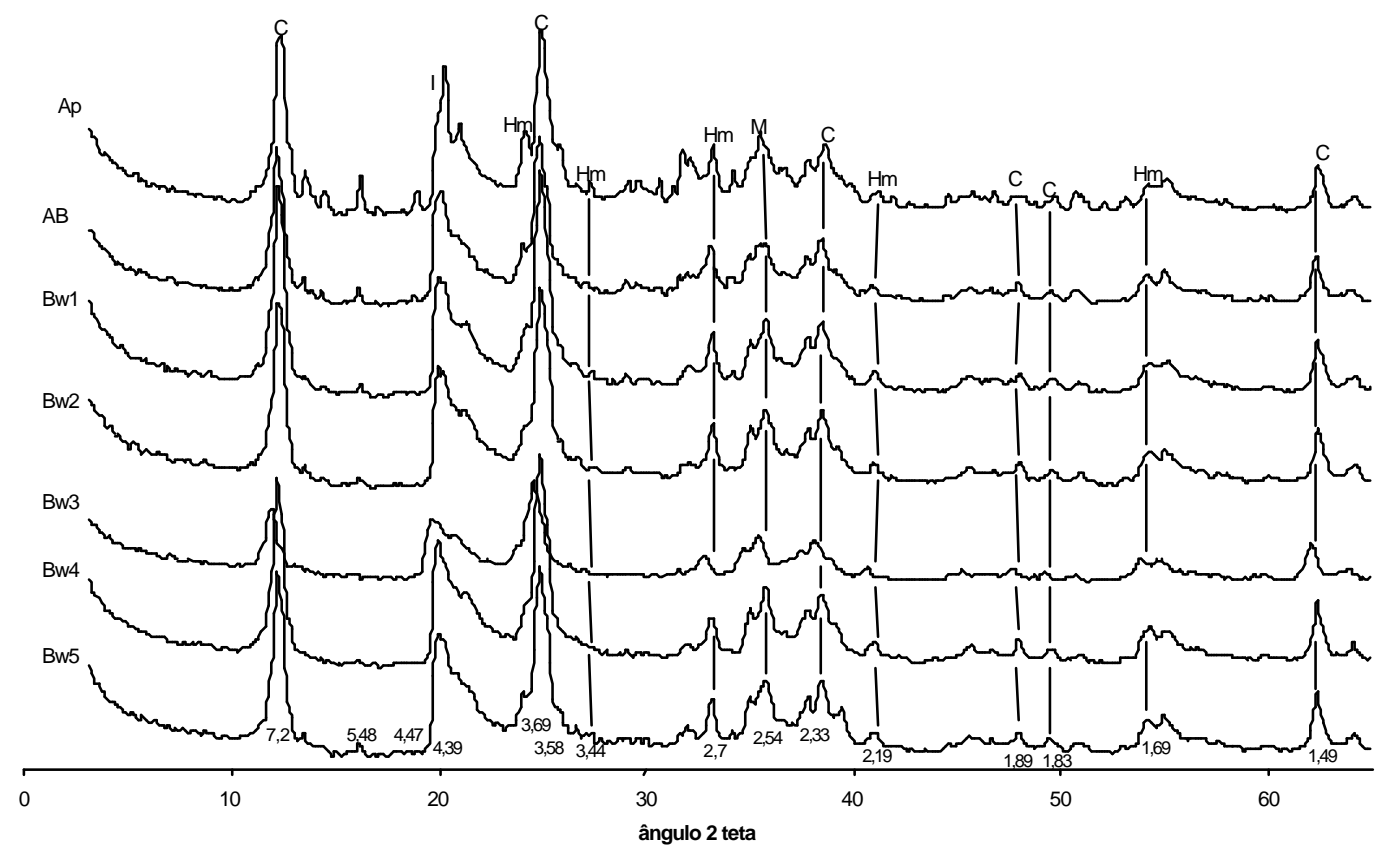

Figura 9 - Difratogramas de raios-X da fração argila das amostras sem tratamento dos horizontes do perfil P3. Estão assinaladas, abaixo dos picos, as respectivas distâncias interplanares, em Å. C- caolinita; Hm- hematita; Mmagnetita e/ou maghemita.

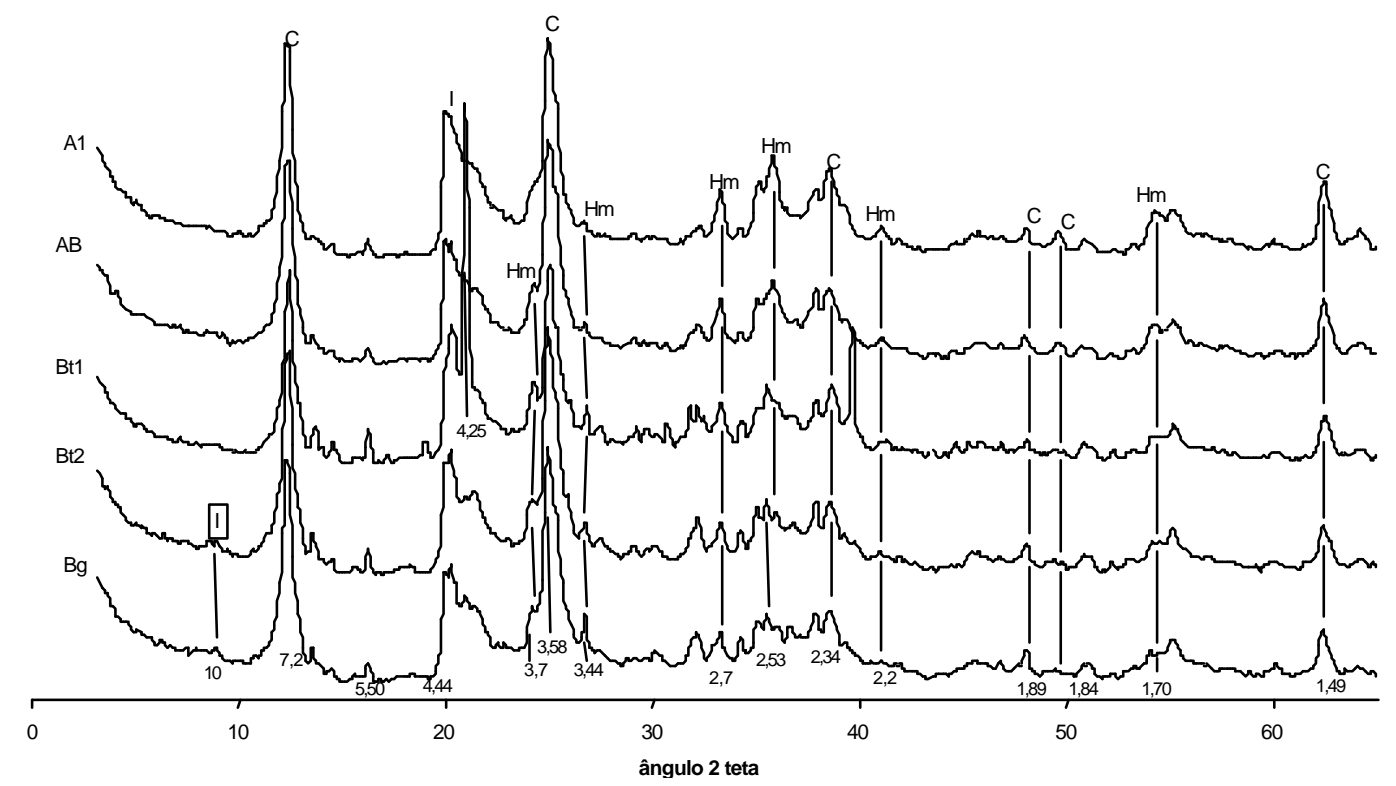

Figura 10 - Difratogramas de raios- $X$ da fração argila das amostras sem tratamento dos horizontes do perfil P4. Estão assinaladas, abaixo dos picos, as respectivas distâncias interplanares, em A. C- caolinita; Hm- hematita; Mmagnetita e/ou maghemita. 


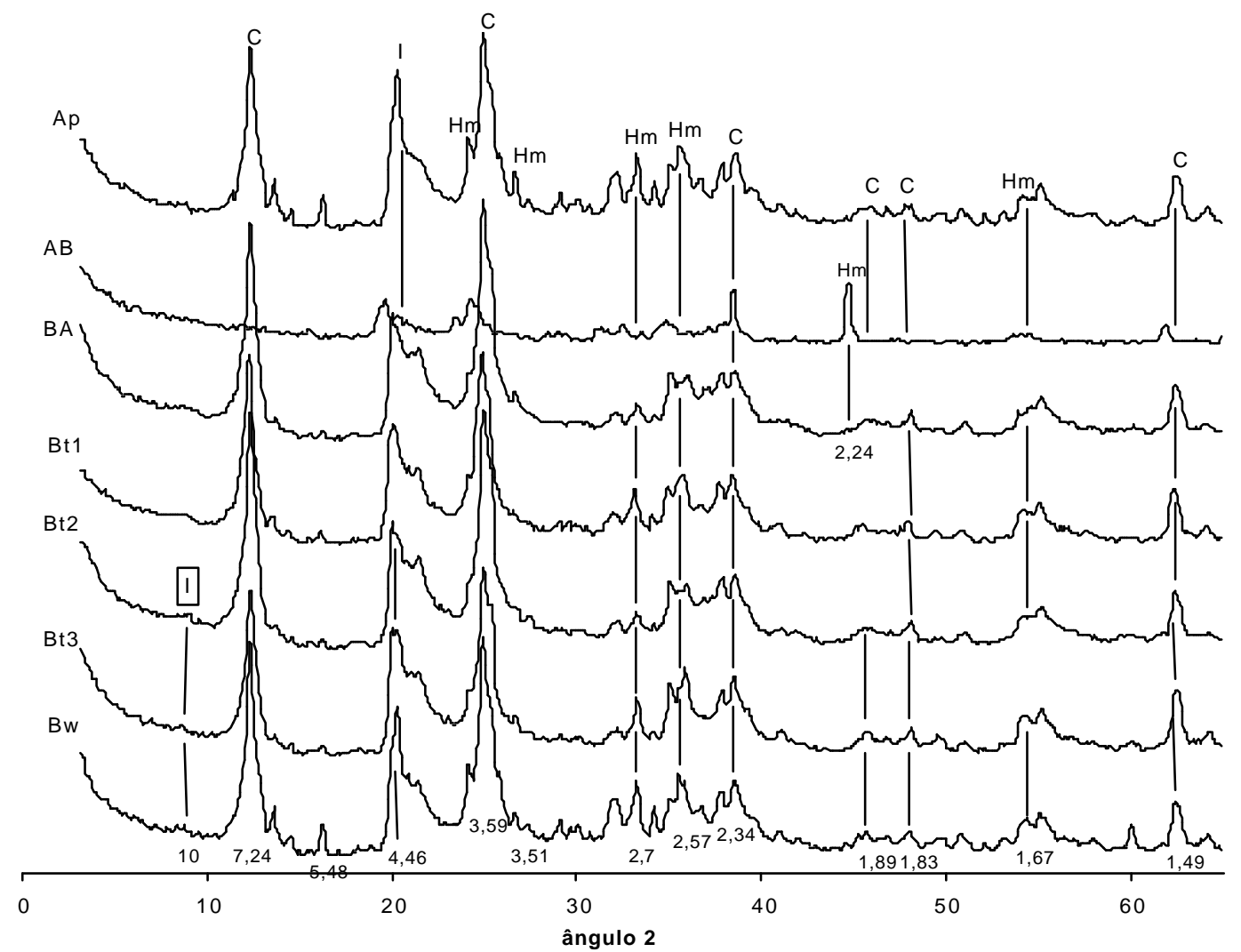

Figura 11 - Difratogramas de raios- $X$ da fração argila das amostras sem tratamento dos horizontes do perfil P5. Estão assinaladas, abaixo dos picos, as respectivas distâncias interplanares, em $\AA$. C- caolinita; Hm- hematita; Mmagnetita e/ou maghemita. 


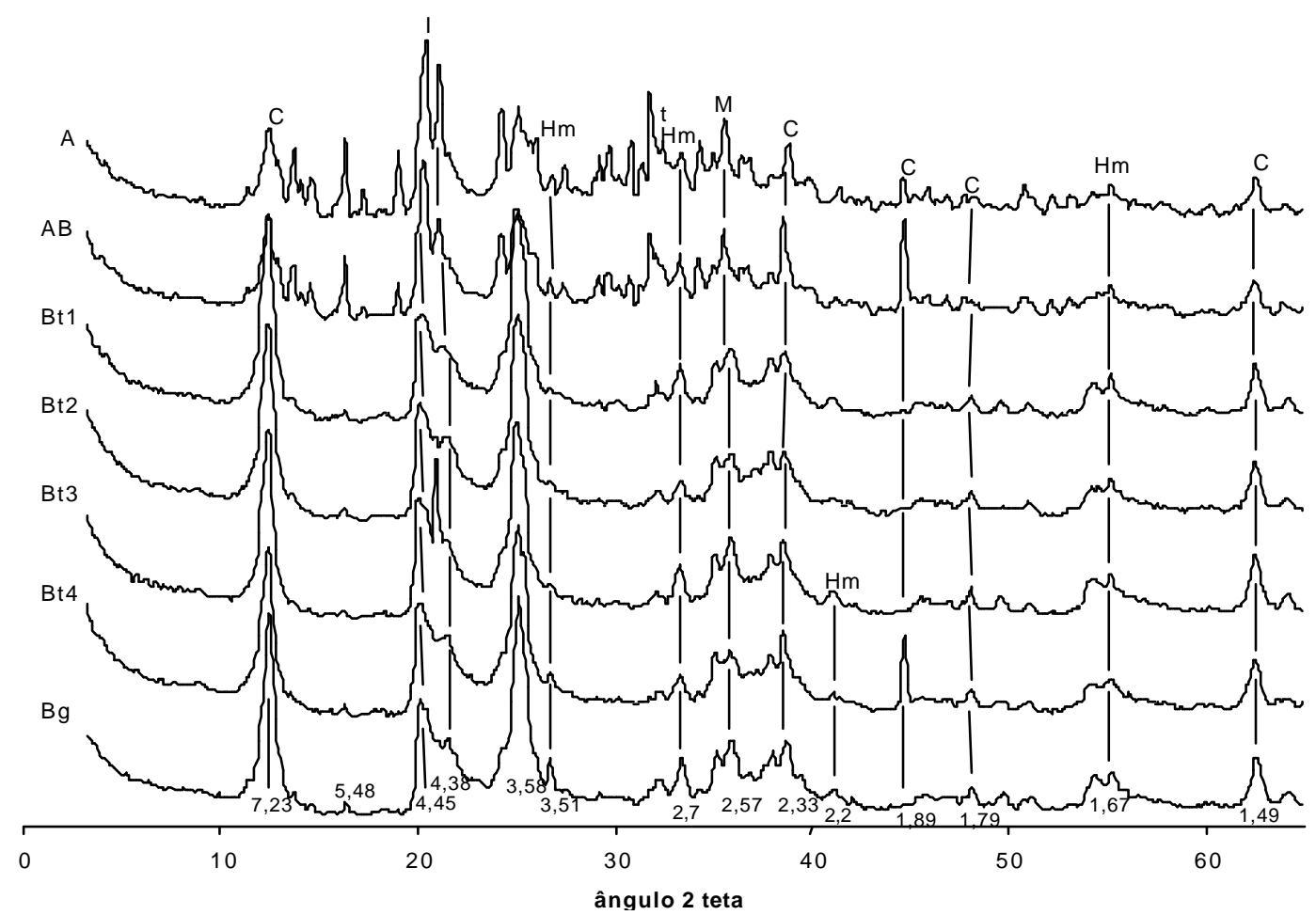

Figura 12 - Difratogramas de raios-X da fração argila das amostras sem tratamento dos horizontes do perfil P6. Estão assinaladas, abaixo dos picos, as respectivas distâncias interplanares, em $\AA$. C- caolinita; Hm- hematita; Mmagnetita e/ou maghemita.

\subsubsection{Minerais pesados}

A análise dos minerais pesados teve como objetivo determinar se existe discontinuidade litológica entre os horizontes dos solos estudados e também comprovar a filiação desta cobertura pedológica com os sedimentos da Formação Adamantina, assim como observado por Queiroz Neto et al. (1973) e Moniz \& Carvalho (1973)

Todos os horizontes analisados mostram a mesma assembléia mineralógica, sem variações significativas nos seus teores, tanto entre os horizontes de um mesmo perfil, quanto entre os perfis ao longo das topossequências, indicando estarem regularmente distribuídos.

A mineralogia identificada, em ordem decrescente de ocorrência, é a seguinte: 
$\checkmark$ minerais pesados opacos: chegam a constituir $90 \%$ do total das lâminas, sendo a maior parte limonita e ilmenita.

$\checkmark$ minerais pesados opacos magnéticos: principalmente constituídos por magnetita. Houve dificuldade na pesagem desta assembléia, devido a problemas com a separação com imã manual.

$\checkmark$ minerais pesados transparentes: ocorrem em cerca de $10 \%$ das lâminas dos horizontes analisados. Devido à grande estabilidade, zircão e turmalina predominam sobre os demais minerais identificados, seguidos em proporção bem menor por rutilo e estaurolita. Ainda foram identificados cianita, granada e epidoto.

Esta assembléia mineralógica identificada nos solos da área de estudo, coincide com as análises feitas por Coimbra (1976) para a Fácie C da Formação Baurú, que corresponde atualmente ás Formações Adamantina e Marília (Soares et al. 1980).

Portanto, a identificação e distribuição da assembléia de minerais pesados nos solos da área de estudo, é mais um indicativo de que os arenitos da Formação Adamantina são o material de origem destes solos e que entre seus horizontes não ocorre discontinuidade litológica (Estados Unidos, 1999).

\subsection{Características micromorfológicas dos perfis analisados}

Tendo em vista a possível utilização destes solos como receptor de efluentes, a definição das formas e tamanhos dos poros dos horizontes, através das descrições de lâminas delgadas, constitui um dos aspectos mais importantes da caracterização micromorfológica dos solos ao longo das topossequências. 


\subsubsection{Síntese das características micromorfológicas dos perfis estudados}

As descrições das lâminas delgadas (Apêndice 2) obedeceram critérios propostos por Bullock et al. (1985) e foram feitas do topo para a base de cada perfil.

\section{Perfil 1:}

Foram descritos os horizontes $\mathrm{BA}, \mathrm{Bw}_{1}$ e $\mathrm{Bw}_{2}$.

$\mathrm{Na}$ lâmina do horizonte BA (Figuras 13 a,b) predominam porções de plasma menos denso $(70 \%)$, com trama enáulica e microestrutura em agregados intergranulares. A porosidade interagregada é predominantemente constituída por mesoporos a macroporos finos de empilhamento $(40 \%)$ e mesocavidades (25\%), com tamanhos entre 0,2 e $0,4 \mathrm{~mm}$. Nas porções de plasma mais denso (30\%), com trama porfírica fechada, a microestrutura é em blocos subangulares com tamanhos entre 0,8 a 1,2 $\mathrm{mm}$. A porosidade intragregada é constituída por mesocavidades em torno de $0,1 \mathrm{~mm} e$ microfissuras. A macroporosidade do horizonte (13\%) é representada por canais que variam de 1,0 a 5,0 mm e câmaras até $15 \mathrm{~mm}$; os canais por vezes apresentam-se preenchidos por material adjacente, originando ortotúbulos.

O horizonte $\mathrm{Bw}_{1}$ (Figura 13c)tem predomínio de trama enáulica $(70 \%)$, microestrutura em agregados intergranulares e porosidade de empilhamento $(50 \%)$ e mesocavidades (30\%), com tamanhos entre 0,3 e $0,8 \mathrm{~mm}$. Os blocos subangulares (30\%) tem tamanhos entre 0,4 e $1,2 \mathrm{~mm}$ e mesoporosidade cavitária intragregrada com tamanhos médios de 0,1 $\mathrm{mm}$. Canais variam de 2,0 a 8,0 mm e câmaras de 10,0 a $15,0 \mathrm{~mm}$, perfazendo $10 \%$ da porosidade.

No horizonte $\mathrm{Bw}_{2}$ (Figura 13d) também predomina trama enáulica (80\%) com microagregados granulares e porosidade de empilhamento $(50 \%)$ e cavitária $(30 \%)$ de mesmas dimensões que horizonte anterior. Os blocos subangulares (20\%) tem tamanhos entre 0,3 e $0,8 \mathrm{~mm}$, com porosidade intragregrada microfissural e microcavitária, esta com dimensões em torno de $0,02 \mathrm{~mm}$. Os canais (5\%) tem dimensões de 2,0 a 6,0 mm 
Em todo o perfil, observa-se o predomínio da porosidade interagregada, representada pela meso e macroporosidade de empilhamento e mesoporosidade cavitária. A macroporosidade é representada por canais e câmaras e chega a atingir até $13 \%$ da porosidade no horizonte BA.

\section{Perfil 3}

Foram descritos os horizontes $\mathrm{Bw}_{2}, \mathrm{Bw}_{3}, \mathrm{Bw}_{4}$ e $\mathrm{Bw}_{5}$.

O horizonte $\mathrm{Bw}_{2}$ apresenta predomínio da trama enáulica $(80 \%)$ e microestrutura em agregados intergranulares, com mesoporosidade de empilhamento (40\%) e cavitária (20\%), com tamanhos entre 0,08 e 0,3 mm. Nas porções de trama porfírica (20\%), os blocos subangulares variam de 0,3 a $0,8 \mathrm{~mm}$, alguns com até $2,5 \mathrm{~mm}$, tem porosidade intragregada microfissural e mesocavitária, com tamanhos médios de 0,05 mm. A macroporosidade é representada por canais (20\%) que variam de 0,6 a 2,5 $\mathrm{mm}$.

As descrições dos horizontes $\mathrm{Bw}_{3}, \mathrm{Bw}_{4}$ (Figura 14) e Bw (Figura 15) são semelhantes. Ocorre predomínio da trama enáulica (cerca de 90\%), mesoporosidade interagregada cavitária (cerca de 50\%), com tamanhos médios de $0,3 \mathrm{~mm}$ e de empilhamento (cerca de $25 \%$ ). Os blocos angulares variam de 0,15 a $1,0 \mathrm{~mm}$, com porosidade intragregada mesocavitária e microfissural. A macroporosidade (10\%) é representada por canais que variam de 2,0 a 10,0 $\mathrm{mm}$ em $\mathrm{Bw}_{3}$ e $\mathrm{Bw}_{4}$ e de 1,0 a 5,0 mm em Bw5.

Neste perfil, observam-se fissuras em sua maioria curvas e em ziguezague em todos os blocos, assim como ligeira diminuição do tamanho dos blocos subangulares de $\mathrm{Bw}_{1}$ para $\mathrm{Bw}_{4}$. Em todo o perfil, predomina a mesoporosidade cavitária e de empilhamento, os canais tem média de 10\% em cada horizonte, com tamanhos que variam entre 0,6 e 10,0 mm. 

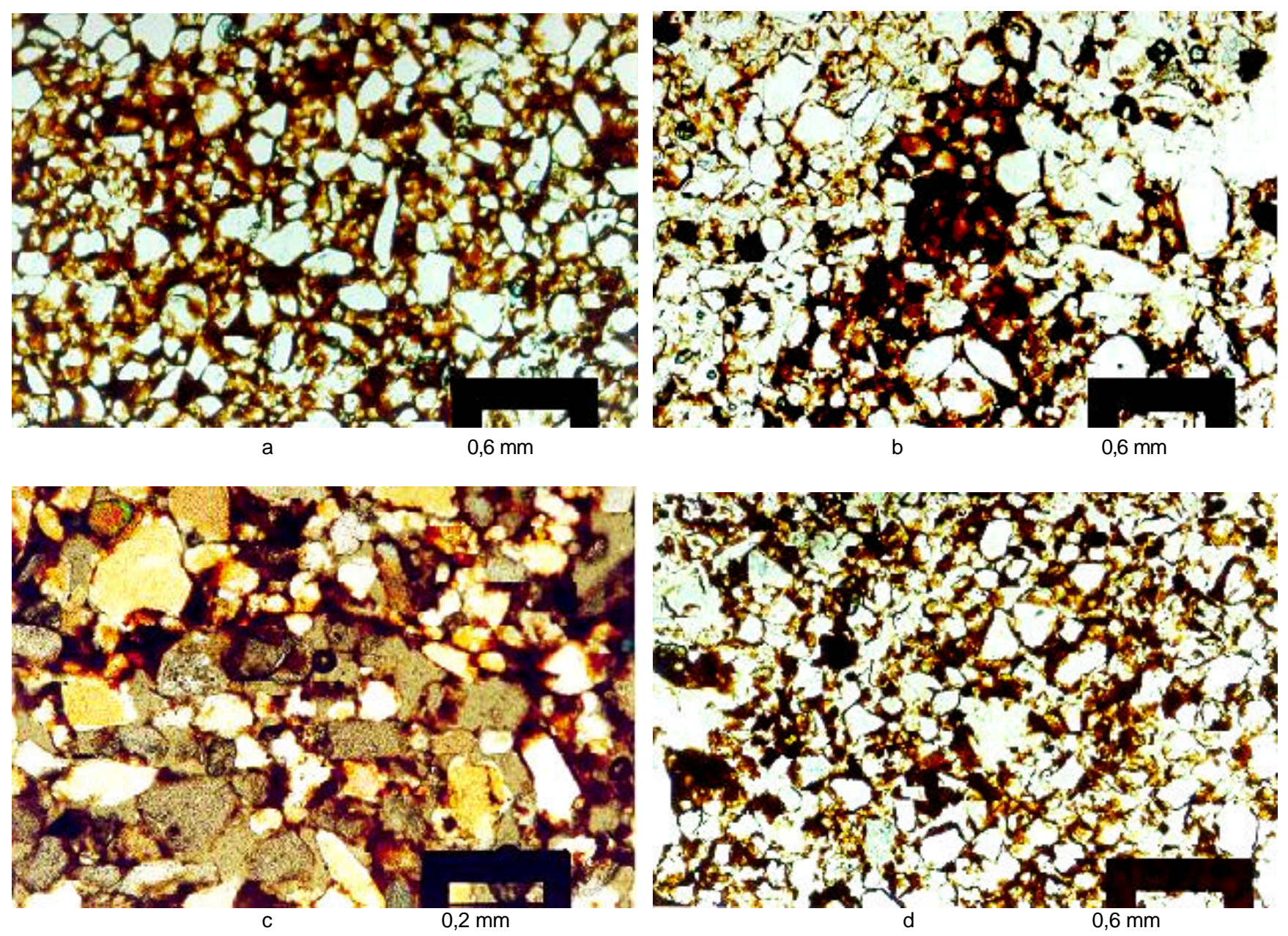

Figura 13 - Fotomicrografias das lâminas do perfil P1. (a) Horizonte BA: trama enáulica á porfírica com porosidade cavitária interagregada; (b) Horizonte BA: bloco sub-angular com trama porfírica, delimitado por porosidade de empilhamento, em meio ao plasma pouco denso; (c) Horizonte $\mathrm{Bw}_{1}$ : plasma recobrindo grãos de quartzo e microagregados em trama enáulica; (d) Horizonte $\mathrm{Bw}_{2}$ : aspecto geral da lâmina, onde predominam os microagregados granulares e a porosidade de empilhamento, com pequenos blocos subangulares á esquerda. 


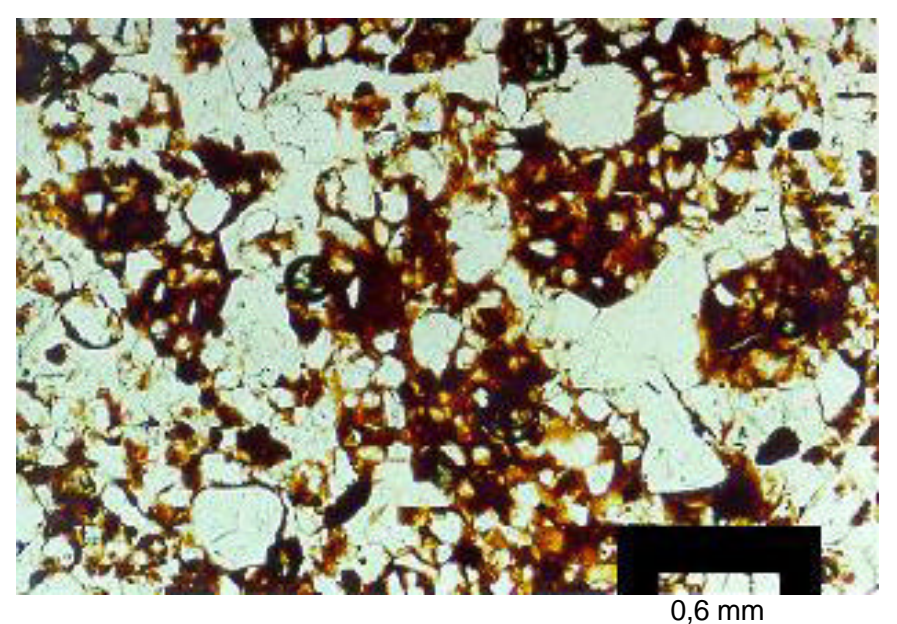

Figura 14 - Fotomicrografia de lâmina do perfil P3, horizonte $\mathrm{Bw}_{4}$, mostrando :blocos subangulares microfissurados com pedalidade moderadamente desenvolvida em meio á macroporosidade de empilhamento.

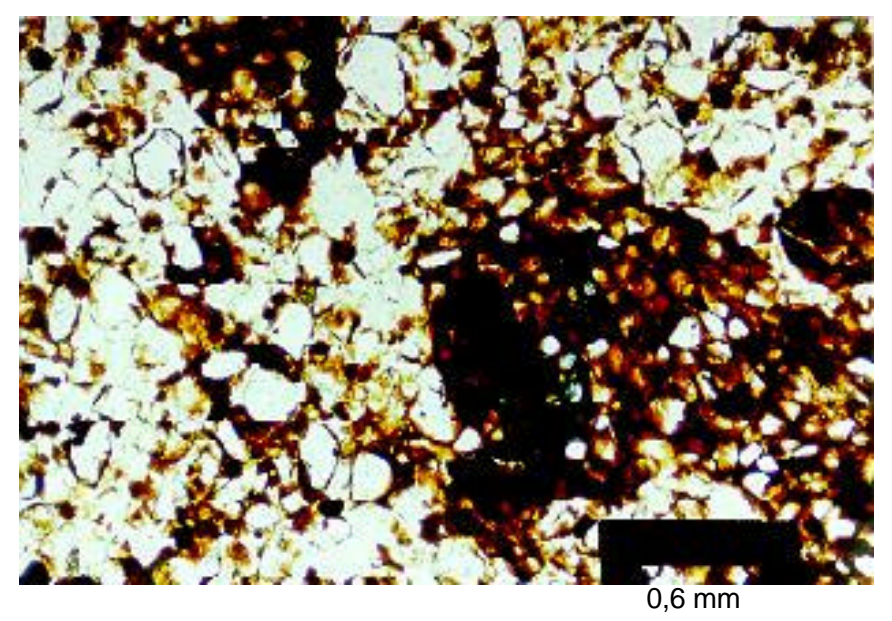

Figura 15 - Fotomicrografia de lâmina do perfil P3, horizonte $\mathrm{Bw}_{5}$, mostrando: microagregados granulares entre os grãos do esqueleto nas porções mais claras e blocos subangulares milimétricos $\mathrm{c} /$ porosidade cavitária intragregada, á direita e acima, nas porções escuras. 


\section{Perfil 5}

Foram descritos os horizontes $\mathrm{BA}, \mathrm{Bt}_{1}, \mathrm{Bt}_{2}, \mathrm{Bt}_{3}$ e $\mathrm{Bw}$.

No horizonte BA predomina trama enáulica $(60 \%)$, microestrutura em agregados intergranulares e porosidade de empilhamento $(30 \%)$ e mesocavitária (40\%) com tamanhos médios de $0,1 \mathrm{~mm}$. Ocorrem hiporevestimentos ( $5 \%$ do total da lâmina) na porosidade de empilhamento junto á grãos do esqueleto dentro dos blocos subangulares, são nítidos, com contraste moderado e não laminados. A trama porfírica (40\%) tem blocos subangulares com tamanhos entre 0,2 e 0,8 mm, mesoporosidade cavitária e microporosidade fissural intragregadas.

O horizonte $\mathrm{Bt}_{1}$ tem predomínio de trama enáulica (60\%), microestrutura em agregados intergranulares, porosidade de empilhamento (30\%) e cavitária (40\%) entre 0,05 e $0,2 \mathrm{~mm}$. Os blocos subangulares (40\%) tem tamanhos entre 0,2 e 1,0 mm, com microporosidade fissural e mesoporosidade cavitária. A macroporosidade (20\%) é representada por canais de até 1,0 mm. Também ocorrem hiporevestimentos associados aos blocos, perfazendo $1 \%$ da lâmina.

O horizonte $\mathrm{Bt}_{2}$ tem predomínio de trama enáulica (70\%), microestrutura em agregados intergranulares, porosidade de empilhamento (45\%) e mesocavitária, com tamanhos entre 0,06 e 0,2 mm. Os blocos subangulares tem tamanhos entre 0,2 e 1,0 mm e porosidade mesocavitária e microfissural. Os canais (10\%) variam de 0,6 a $1,5 \mathrm{~mm}$. Presença de hiporevestimentos associados aos blocos subangulares.

No horizonte $\mathrm{Bt}_{3}$ (Figura 16) predomina trama enáulica $(70 \%)$ com porosidade de empilhamento (40\%) e mesocavitária (30\%), com tamanho médio de $0,4 \mathrm{~mm}$. Os blocos subangulares (30\%) são melhores definidos e variam de 0,2 a $1,5 \mathrm{~mm}$, com microporosidade intragregada fissural curvilínea predominando sobre a cavitária. Presença de canais (5\%) de 0,4 a 2,5 mm. Ocorrem hiporevestimentos dentro dos agregados e revestimentos associados á porosidade de empilhamento. 
No horizonte Bw (Figura 17) aumenta o predomínio da trama enáulica (85\%) com agregados intergranulares e ocorre a diminuição da trama porfírica (15\%), com blocos subangulares mal definidos entre 0,1 e $0,5 \mathrm{~mm}$. com tamanho médio de 0,6 mm. Presença de ortotúbulos milimétricos e canais (5\%) em torno de $1 \mathrm{~mm}$.

\section{Perfil 2}

Foram descritos os horizontes $\mathrm{BA}, \mathrm{Bt}_{1}, \mathrm{Bt}_{2}, \mathrm{Bt}_{3}$ e Btg.

No horizonte BA (Figura 18a), predomina a trama enáulica (85\%), com porosidade de empilhamento (40\%) e mesocavitária (20\%). A trama porfírica (15\%) tem blocos subangulares de 0,8 a $2,5 \mathrm{~mm}$, com porosidade intragregada cavitária e por vezes fissural e interagregada de empilhamento.

O horizonte $\mathrm{Bt}_{1}$ (Figura 18b) apresenta maior quantidade de plasma que o anterior, evidenciado pelo aparecimento de revestimentos preenchendo a porosidade cavitária (de 0,3 $\mathrm{mm}$ em média) entre os pedes granulares. São revestimentos de argila laminados, com contraste forte e proeminente, ocorrendo em $5 \%$ da lâmina. A trama porfírica (20\%) tem blocos subangulares um pouco menores (entre 0,15 e 1,0 mm) que do horizonte anterior.

$\mathrm{O}$ horizonte $\mathrm{Bt}_{2}$ (Figura $18 \mathrm{c}$ ) é muito semelhante ao anterior, porém não foram observados revestimentos. Nos blocos subangulares (10\%), entre $0,1 \mathrm{e}$ 0,4 $\mathrm{mm}$ predomina mesoporosidade cavitária, em detrimento da pouca porosidade fissural. Na lâmina predominam os microagregados intergranulares ultra-finos, com porosidade cavitária de $0,15 \mathrm{~mm}$ em média Presença de grandes ortobúlos.

$\mathrm{O}$ horizonte $\mathrm{Bt}_{3}$ apresenta um macroagregado centimétrico em bloco subangular, com plasma vermelho muito escuro, isótico; a trama é porfírica fechada e a porosidade intragregada é ausente. $\mathrm{Na}$ lâmina, predomina a trama enáulica, com plasma menos denso que horizonte anterior. A porosidade de empilhamento é mais comum que a cavitária. 


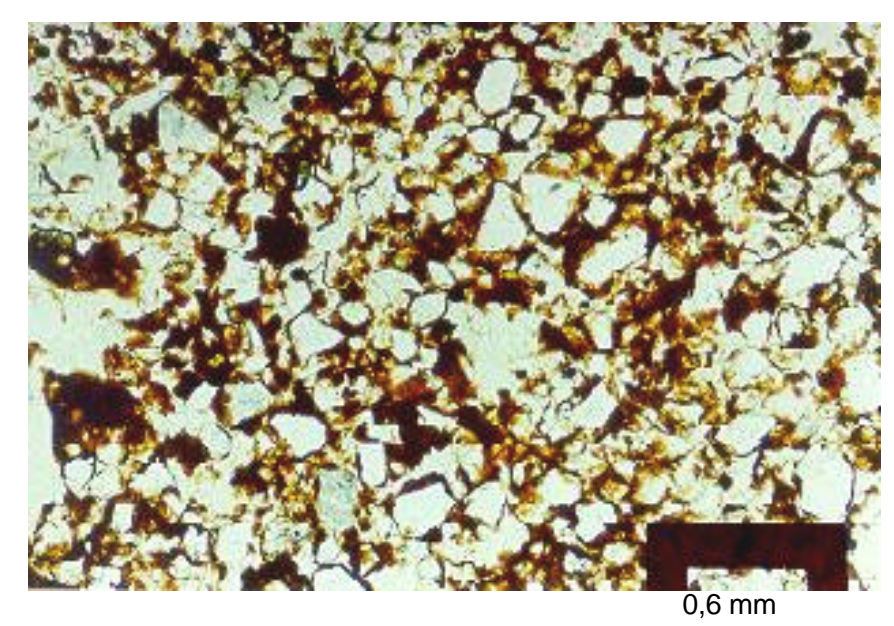

Figura 16 - Fotomicrografia de lâmina do perfil P5, horizonte $\mathrm{Bt}_{3}$, mostrando o predomínio de microagregados intergranulares e da porosidade de empilhamento.

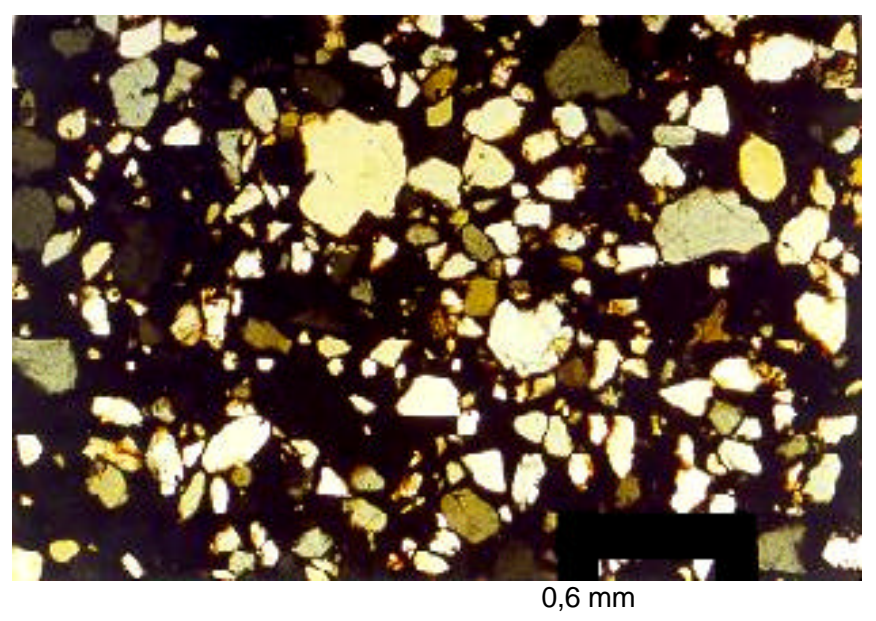

Figura 17- Fotomicrografia de lâmina do perfil P5, horizonte $\mathrm{Bw}$, mostrando predomínio de trama enáulica e porosidade de empilhamento. Observar grãos do esqueleto quartzoso, com predomínio da fração $0,15 \mathrm{~mm}$ (areia fina). 
O horizonte Btg (Figura 18d) apresenta plasma menos denso ainda, de trama enáulica $(85 \%)$ com predomínio de porosidade de empilhamento. Nas poucas porções mais densas, os blocos subangulares (5\%) são menores $(0,2$ a $0,3 \mathrm{~mm}$ ) e menos definidos e a microporosidade intragregada cavitária também predomina sobre a fissural.

\section{Perfil 6}

Foram descritos os horizontes $\mathrm{Bt}_{2}, \mathrm{Bt}_{3}, \mathrm{Bt}_{4}$ e Btg.

$O$ horizonte $\mathrm{Bt}_{2}$ tem predomínio da trama porfírica $(60 \%)$, em concordância com a análise granulométrica, que indicou ser este o horizonte com maior concentração de argila ao longo da topossequência. As porções de trama enáulica $(40 \%)$ tem porosidade entre os microagregados em menores proporções, sendo de empilhamento (10\%) e mesocavitária (20\%), entre 0,2 e 0,4 mm. Os blocos subangulares, entre 0,2 e 0,8 mm são mal definidos, cuja porosidade intragregada $(70 \%)$ é predominantemente cavitária $(60 \%)$, com tamanhos entre 0,05 e 0,3 $\mathrm{mm}$ e a interagregada é de empilhamento. Presença de hiporevestimentos (1\%) associados aos blocos subangulares e revestimentos (1\%) preenchendo a porosidade de empilhamento.

O horizonte $\mathrm{Bt}_{3}$ (Figura 19) apresenta predomínio da trama enáulica (60\%) e porosidade de empilhamento e cavitária entre 0,2 e 0,6mm. A trama porfírica (40\%) tem blocos subangulares de tamanhos entre 0,2 e 1,0 $\mathrm{mm}$ e microporosidade intragregada cavitária e fissural. Presença de macroporosidade (10\%) representada por canais que variam de 0,5 a $2,5 \mathrm{~mm}$. 


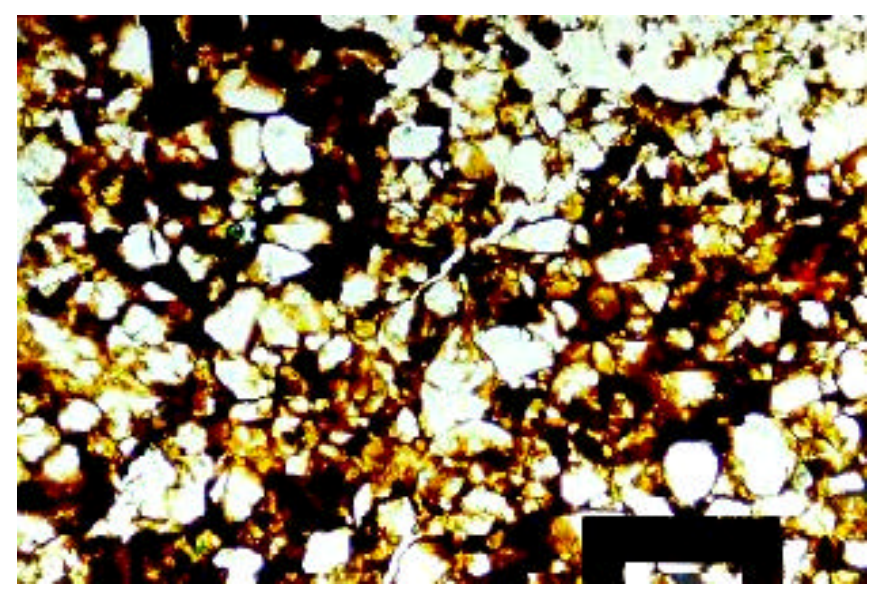

a

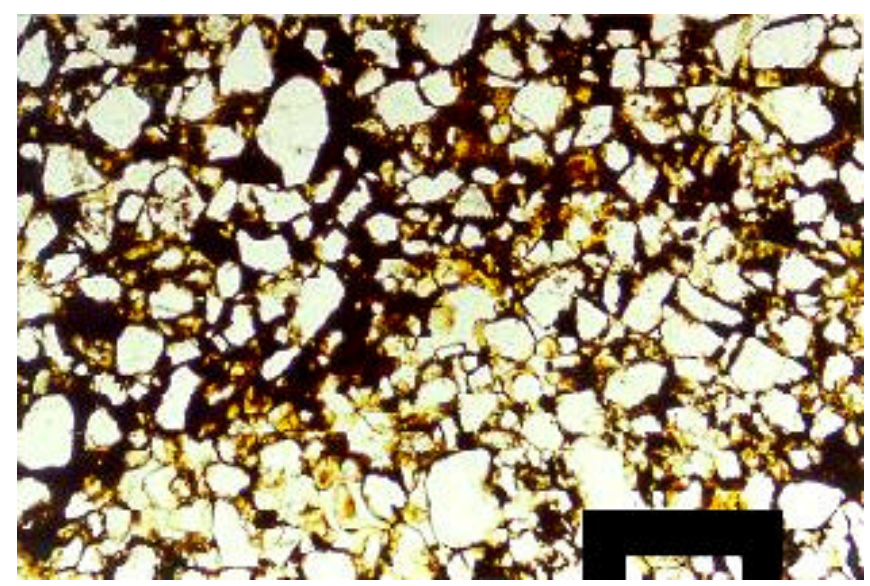

C
$0,6 \mathrm{~mm}$

$0,6 \mathrm{~mm}$

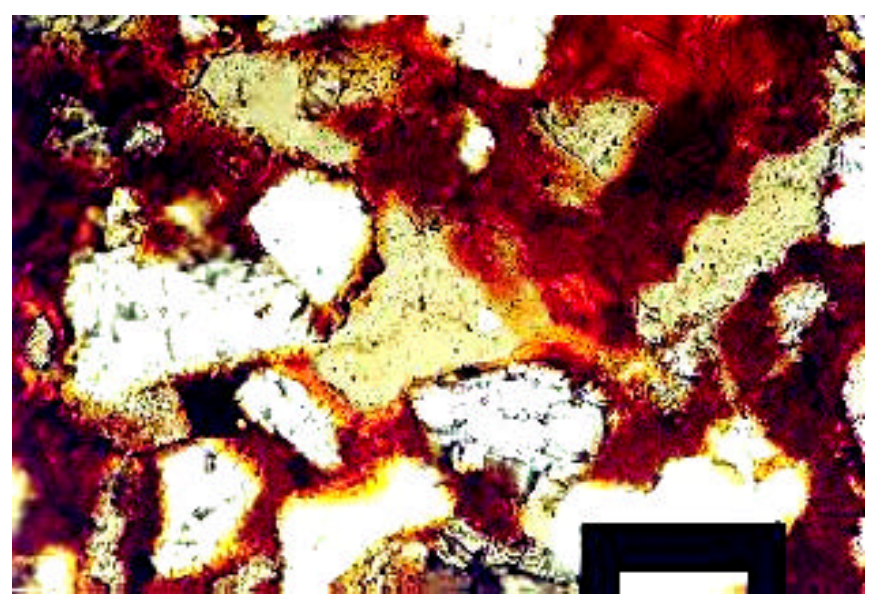

b

$0,1 \mathrm{~mm}$

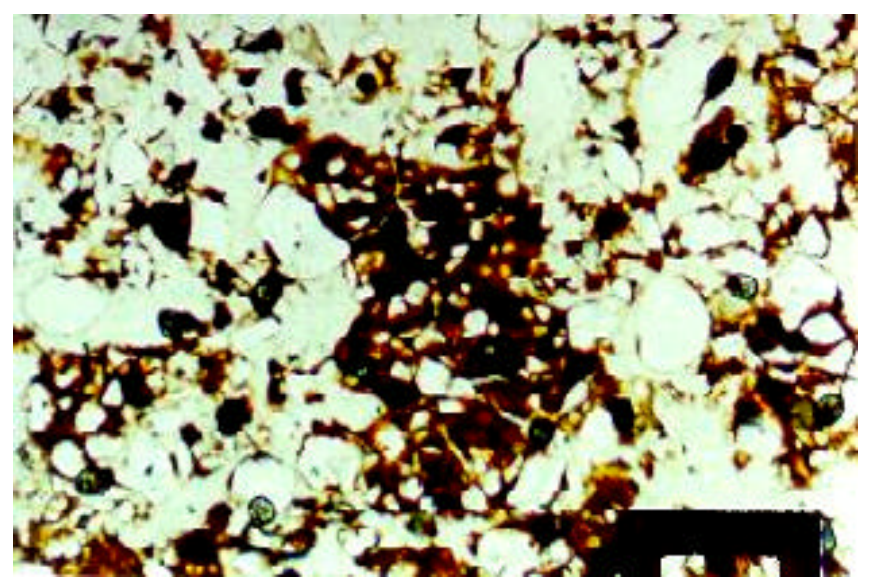

$0,6 \mathrm{~mm}$

Figura 18 - Fotomicrografias de lâminas do perfil P2 . (a) Horizonte BA, mostrando trama porfírica com blocos subangulares mal definidos delimitados por porosidade fissural e de empilhamento. (b) Horizonte $\mathrm{Bt}_{1}$, mostrando revestimento de argila preenchendo a porosidade de empilhamento e originando cavidade. (c) Horizonte $\mathrm{Bt} 2$, mostrando limite entre trama porfírica e trama enáulica (d) Horizonte Btg, mostrando bloco subangular com microfissuras e mesocavidades em meio ao plasma pouco denso. 
O horizonte $\mathrm{Bt}_{4}$ também tem predomínio da trama enáulica (70\%) com porosidade de empilhamento (30\%) e cavitária (40\%) entre 0,1 e $0,4 \mathrm{~mm}$. A trama porfírica (30\%) tem blocos subangulares menores, com tamanhos entre 0,2 e 0,5 mm e poros mesocavitários e microfissurais intragregados. Os canais (5\%) variam de 1,0 a 2,0 $\mathrm{mm}$.

O horizonte Btg (Figura 20) tem menor proporção de trama porfírica (20\%) e blocos subangulares de tamanhos entre 0,2 e 0,5mm, com microporosidade intragregada cavitária, em torno de 0,01 mm, e fissural. Predomínio da trama enáulica (80\%) com porosidade de empilhamento $(30 \%)$ e cavitária (45\%), que varia de 0,1 a $0,4 \mathrm{~mm}$. Presença de hiporevestimentos associados aos blocos subangulares e revestimentos preenchendo a porosidade de empilhamento. Os canais (10\%) variam de 1,0 a 2,5 mm.

\section{Perfil 4}

Foram descritos os horizontes $\mathrm{Bt}_{1}, \mathrm{Bt}_{2}$ e $\mathrm{Btg}$.

$\mathrm{O}$ horizonte $\mathrm{Bt}_{1}$ apresenta predomínio de trama enáulica $(70 \%)$ e porosidade de empilhamento (30\%) e cavitária (55\%) com tamanhos médios de 0,08 e $0,6 \mathrm{~mm}$. A trama porfírica $(30 \%)$ tem os blocos subangulares que aparecem como esqueletos, restando apenas as bordas em trama fechada, porém com plasma menos denso no interior, dominado por porosidade de empilhamento. Canais (10\%) representando a macroporosidade. Pequenos hiporevestimentos muito aderidos ao plasma nestas bordas porfíricas.

$\mathrm{O}$ horizonte $\mathrm{Bt}_{2}$ (Figuras 21 e 22) tem predomínio da trama enáulica (85\%) e porosidade de empilhamento (20\%) e cavitária (60\%) entre 0,1 e 1,0 $\mathrm{mm}$. A trama porfírica (15\%)tem blocos com tamanhos entre 0,4 e 1,0 mm, com mesoporosidade dominante cavitária. Canais perfazem $10 \%$ da lâmina. Presença de revestimentos típicos (10\%) na porção superior da lâmina preenchendo a porosidade de empilhamento.

O horizonte Btg é semelhante ao anterior. 


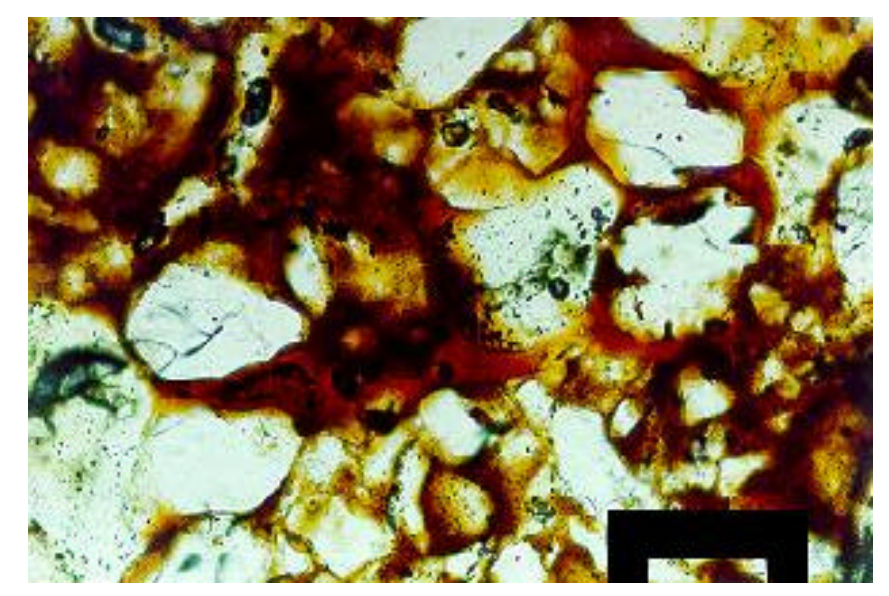

$0,2 \mathrm{~mm}$

Figura 19 - Fotomicrografia de lâmina do perfil P6, horizonte $\mathrm{Bt}_{3}$, mostrando- revestimento tipo cobertura conectada preenchendo a porosidade de arranjo entre os grãos do esqueleto.

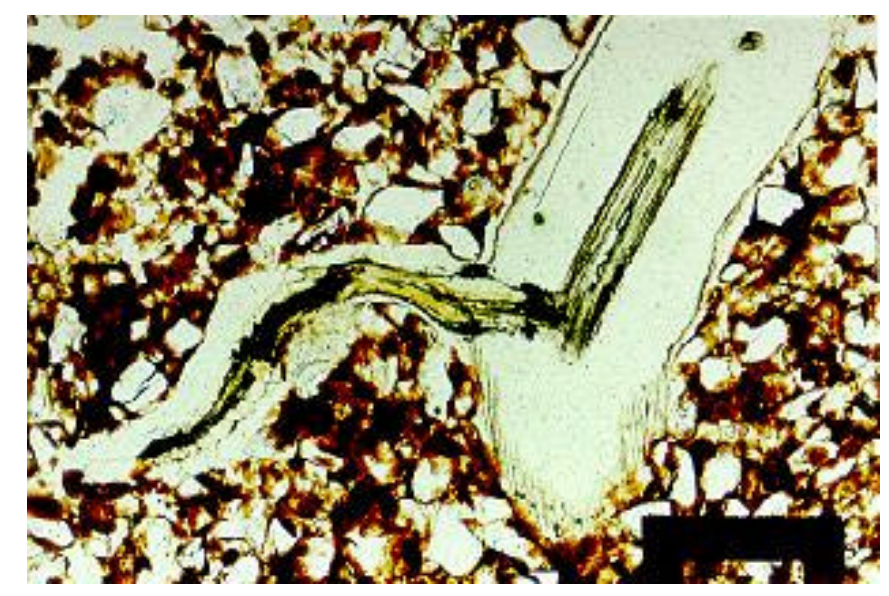

$0,6 \mathrm{~mm}$

Figura 20 - Fotomicrografia de lâmina do perfil P6, horizonte Btg, mostrando canal preenchido por raiz. 


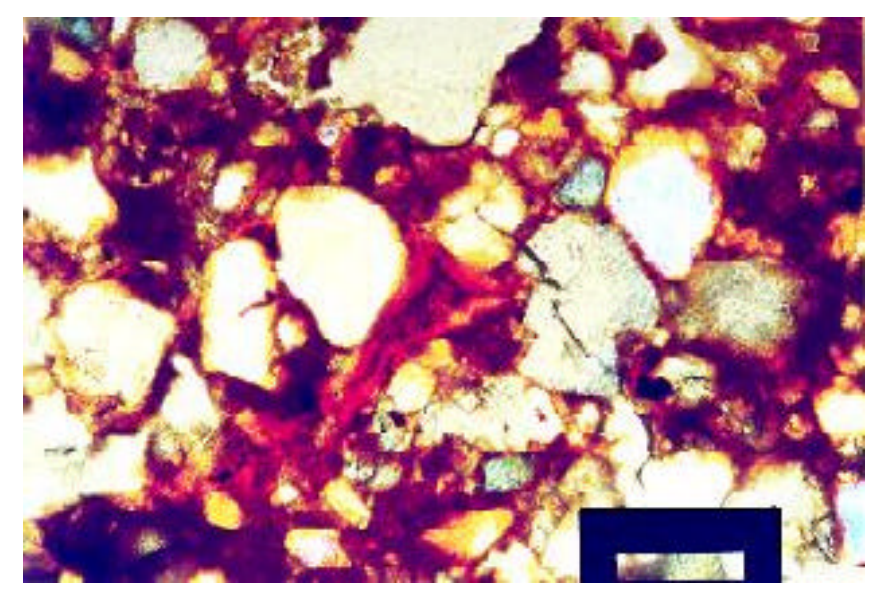

$0,2 \mathrm{~mm}$

Figura 21 - Fotomicrografia de lâmina do perfil $\mathrm{P} 4$, horizonte $\mathrm{Bt}_{2,}$, mostrando revestimento típico de argila preenchendo porosidade cavitária.

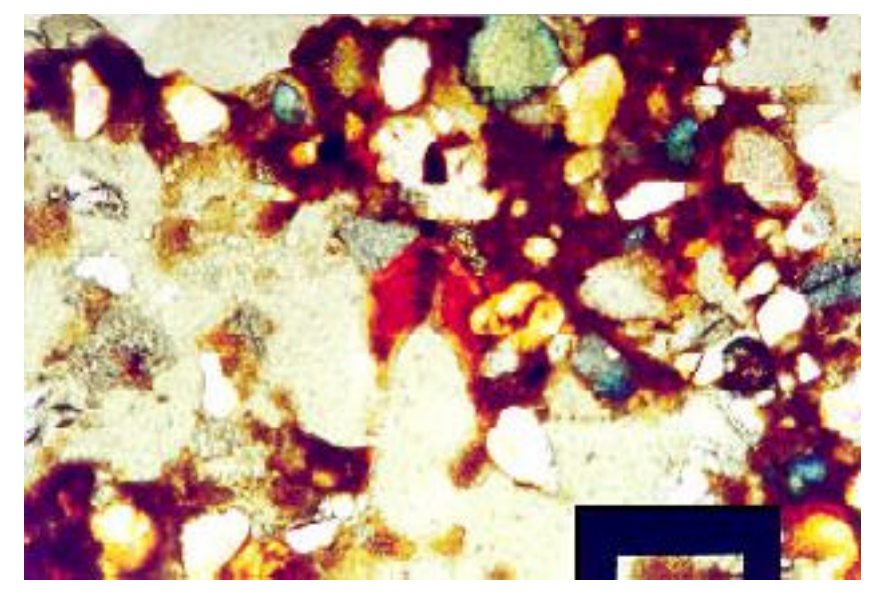

$0,1 \mathrm{~mm}$

Figura 22 - Fotomicrografia do perfil $\mathrm{P} 4$, horizonte $\mathrm{Bt}_{2}$, mostrandorevestimento típico de argila laminado e zonado preenchendo a porosidade cavitária. 


\subsubsection{Esquema geral das lâminas analisadas}

Todas as lâminas analisadas apresentam grande homogeneidade. As variações observadas são o aparecimento de revestimentos e diferentes proporções entre plasma mais denso e menos denso, que condicionam a presença, quantidade e tamanho de blocos subangulares e consequentemente, o sistema poroso.

\section{Esqueleto}

O esqueleto é constituído por grãos de quartzo (97\%), minerais opacos $(2 \%)$ e minerais pesados transparentes $(1 \%)$.

Os tamanhos variam entre 0,05 e 0,4mm, com predomínio de 0,15 mm. Os constituintes são anedrais, bem selecionados, subarredondados, moderadamente esféricos, lisos, contrastes distintos, nítidos, variabilidade baixa, com orientação relativa enáulica, quitônica, gefúrica e/ou porfírica.

\section{Estruturas plásmicas}

O plasma dos microagregados granulares não apresenta orientações, é indiferenciado ou isótico, segundo Brewer (1976).

Nos blocos subangulares foram identificadas 3 tipos de estruturas: em pequenas manchas individuais e isoladas de argila (salpicada grânica), em domínios de argilas orientadas em padrão mosaico (salpicada em mosaico) e partículas de argila orientadas paralelamente ás paredes dos grãos do esqueleto granoestriada). Nos 2 primeiros tipos, as extinções são difusas, enquanto na granoestriada são curvilíneas.

\section{Microestrutura e agregados}

Em todas as lâminas, a microestrutura predominante é constituída por agregados esferoidais não porosos (microagregados granulares) ultra-finos $(<0,5 \mathrm{~mm})$. São estruturas com forte agregação (pedalidade fortemente desenvolvida), que podem ou não se tocar uns aos outros ou estarem ligados 
ou não aos grãos do esqueleto, definindo microestrutura em microagregados intergranulares,

Nas porções onde o plasma é mais denso, ocorre microestrutura em blocos subangulares ultra-finos $(<1,0 \mathrm{~mm}$ ) a muito finos ( entre 1,0 e $5,0 \mathrm{~mm}$ ), com pedalidade fraca a moderadamente desenvolvida, tem superfície ondulada e não são acomodados entre si. A superfície ondulada deve-se ao fato destas estruturas estarem delimitadas pela porosidade de empilhamento, tornando-as como formas mal definidas.

\section{Trama}

Os tipos de trama são definidos em função do arranjo ou distribuição relativa entre o esqueleto, o plasma e os poros. Nas lâminas foram observados dois tipos de tramas:

- enáulica: os agregados granulares de plasma ocupam os espaços entre os grãos do esqueleto; está associada ás porções onde o plasma é relativamente menos denso. Predomina em todas as lâminas analisadas. Os agregados podem tanto estar ao redor do esqueleto, afastados ou formando ligações entre estes. É o tipo predominante em todas as lâminas.

- porfírica: os grãos do esqueleto estão cimentados por matriz argilosa (plasma) densa, formando os blocos subangulares;

\section{Feições pedológicas}

Os revestimentos de argila ou cutãs (Brewer, 1976) estão presentes nos perfis dos Argissolos (perfis P5, P6, P2 e P4) e se apresentam sob duas formas principais:

$\checkmark$ hiporevestimentos: nas lâminas dos horizontes BA, Bt1 e Bt2 do perfil 5 , Bt2 e Btg do perfil 6 e Bt1 do perfil 4 foram observados hiporevestimentos externos de grãos dentro dos blocos subangulares, fortemente aderidos ao plasma, com cores vermelho vivo, textura argila fina, orientação fraca a moderada, contraste distinto, nitidez 
clara, não laminados e com linhas de extinção difusas, indicando que as partículas de argila estão parcialmente orientadas entre si.

$\checkmark$ revestimentos de argila típicos: nas lâminas dos horizontes Bt1 do perfil P2, Bt2 do perfil P6 e Bt2 e Btg do perfil P4, são observados revestimentos de argila típicos, entre 1 e $3 \%$ das lâminas, preenchendo a porosidade de empilhamento. Apresentam-se muito nítidos, com extinção forte e contínua, laminados e zonados. O aspecto zonado, com cores vermelhas e amarelas indica que houve segregação de ferro.

\subsubsection{Sistema poroso}

A estabilidade do sistema poroso dos solos é uma das propriedades que afeta a habilidade do solo em armazenar e transmitir ar, água e solutos. Vários mecanismos externos podem influenciar este sistema, incluindo irrigação, aragem, tráfego de máquinas, umedecimento, etc (Nematti et al. 2000).

As análises micromorfológicas, assim como as morfológicas, evidenciam a intensa porosidade ao longo de todos os perfis como uma das principais características destes solos. Análises micromorfológicas permitiram a caracterização da micro, meso e macroporosidade, sendo os tamanhos classificados segundo Bullock et al. (1985, adaptado) (Tabela 5).

Os agregados granulares, que predominam em toda a sequência de solos, originam macro e mesoporosidade de arranjo entre estes pedes. Os grãos do esqueleto quartzoso, amplamente predominante, origina macroporosidade de empilhamento entre si. Ambas são denominadas porosidade de empilhamento. Quando a porosidade de empilhamento é "fechada" por outros agregados granulares, origina-se então a porosidade cavitária interagregada. Os tamanhos dos poros cavitários variam de mesoporos $(0,05 \mathrm{a}$ 0,5mm) a macroporos médios $(0,5 \mathrm{a} 2,0 \mathrm{~mm})$. 
Nas zonas mais densas do plasma, onde ocorrem os blocos subangulares, a porosidade apresenta duas situações: dentro destes agregados (intragregada) ou entre os agregados e as porções menos densas (interagregada).

Tabela 5. Classes de tamanhos dos poros

\begin{tabular}{lll}
\hline CRIPTOPOROS & & $<0,0001 \mathrm{~mm}$ \\
\hline ULTRAMICROPOROS & & $<0,002 \mathrm{~mm}$ \\
\hline MICROPOROS & & $0,002-0,05 \mathrm{~mm}$ \\
\hline \multirow{2}{*}{ MESOPOROS } & Finos & $0,05-0,1 \mathrm{~mm}$ \\
& Médios & $0,1-0,2 \mathrm{~mm}$ \\
& Grandes & $0,2-0,5 \mathrm{~mm}$ \\
\hline \multirow{2}{*}{ MACROPOROS } & Finos & $0,5-1,0 \mathrm{~mm}$ \\
& Médios & $1,0-2,0 \mathrm{~mm}$ \\
& Grandes & $2,0-5,0 \mathrm{~mm}$ \\
\hline
\end{tabular}

Fonte: Bullock et al., 1985 adaptado.

A porosidade intragregada constitui-se de cavidades vazias de formas irregulares dentro do plasma (porosidade cavitária) e de fissuras, devido a processos de expansão e contração dos blocos (porosidade fissural), com amplo predomínio da porosidade cavitária. Esta, varia de 0,01 (microcavidades) á 0,5 (mesocavidades grandes), com predomínio dos tamanhos compreendidos na última classe. Quando os blocos tem pedalidade moderadamente desenvolvida, quase não ocorre porosidade cavitária intragregada, predominando os microporos fissurais. Predominantemente, os blocos subangulares não são delimitados por fissuras, mas pela porosidade de arranjo, que predomina nas porções de plasma menos denso, o que confere o aspecto de dispersão destes agregados subangulares, isto é, os blocos subangulares encontram-se isolados uns dos outros em meio àtrama enáulica, nas porções de plasma pouco denso. 


\subsection{Considerações gerais sobre a dinâmica dos solos ao longo da vertente}

Os solos identificados ao longo da topossequência constituem uma sequência Latossolo - Argissolo, sequência esta, observada por diversos autores ao estudar a gênese dos solos situados na região noroeste do Planalto Ocidental Paulista, desenvolvidos sobre os sedimentos arenosos do Grupo Bauru (Queiroz Neto et al.,1973; Moniz \& Carvalho,1973; Lepsch,1975; Carvalho,1976; Queiroz Neto et al.,1981; Rueda \& Dematte,1988; Castro,1989).

A associação Latossolo - Argissolo só se tornou evidente após os resultados das análises granulométricas, químicas e micromorfológicas dos horizontes dos solos, pois em todas as etapas de campo, desde as tradagens inicias, até a descrição dos perfis e coleta de amostras nas trincheiras, as variações morfológicas entre os perfis ao longo da vertente são pouco perceptíveis.

A transição lateral dos horizontes latossólicos $(\mathrm{Bw})$ para horizontes texturais $(\mathrm{Bt})$ ocorre do topo para a base da vertente.

Nas posições de topo, foi identificado o LATOSSOLO VERMELHO Distrófico típico, representado pelos perfis P1 e P3. Na meia encosta, ocorrem ARGISSOLO VERMELHO e ARGISSOLO VERMELHO-AMARELO Distróficos latossólicos, representados pelos perfis P5 e P2, respectivamente. No sopé da vertente, ocorrem ARGISSOLO VERMELHO e ARGISSOLO AMARELO Distróficos abrúpticos, representados pelos perfis $\mathrm{P} 6$ e $\mathrm{P} 4$, respectivamente.

Esta distribuição dos solos nas topossequências estudadas, é semelhante àencontrada pelos autores anteriormente citados, com exceção de Moniz \& Carvalho (1973), onde os Latossolos ocorrem nas posições de sopé de encosta.

A partir da constatação da existência desta associação de solos, tornouse fundamental para o presente estudo, identificar de que maneira ocorre a transformação Latossolo - Argissolo e se esta transformação faz parte da 
pedogênese atual, em função da possível aptidão destes solos em serem receptores de efluente de estação de tratamento de esgoto.

Sendo assim, buscou-se, através das caracterizações granulométricas, químicas, mineralógicas e micromorfológicas, as principais evidências que pudessem esclarecer a dinâmica atual dos solos em questão.

Foram identificados quatro grupos de evidências. Cada grupo é associado a um evento pedogenético, cuja cronologia é definida do mais antigo para o atual.

O primeiro grupo, cujas evidências constituem o primeiro evento pedogenético identificado, denominado Pedogênese I, está relacionado à transformação dos horizontes latossólicos em texturais, lateralmente, ao longo da vertente e são as seguintes:

1- A relação textural dos perfis analisados evidencia o aumento dos teores de argila nos horizontes subsuperficias e diminuição nos horizontes superficiais em direção ao sopé da vertente, chegando a atingir gradiente textural abrupto nos perfis localizados nas posições mais baixas da vertente.

2- Os valores de saturação por bases também aumentam nos perfis em direção àbase da vertente, sem, contudo, torná-los eutróficos.

3- Nos horizontes Bt1 do perfil P2, Bt2 do perfil P6 e Bt2 e Btg do perfil P4, são observados revestimentos de argila típicos, zonados, em até $3 \%$ das lâminas, preenchendo a porosidade de empilhamento. Estes revestimentos de argila típicos são observados exatamente nos horizontes com os maiores teores de argila ao longo das topossequências, evidenciando argiluviação. Porém, estes só foram visualizados através da micromorfologia, pois nas descrições morfológicas, não foi observada cerosidade em nenhum dos perfis.

A partir destas evidências, pode-se considerar que o mecanismo da transformação Bw - Bt é por transferência de matéria ao longo da vertente, assim como também foi constatado para a gênese de Argissolos na região de Marília (SP), por Castro (1989). 
O segundo grupo envolve as evidências de um evento pedogenético, denominado Pedogênese II, que pode ter atuado tanto simultaneamente quanto posteriormente à instalação da Pedogênese I e também está relacionado à origem dos horizontes Bt. As evidências são:

4- As análises micromorfológicas mostram que, nos horizontes BA, Bt1 e Bt2 do perfil 5, Bt2 e Btg do perfil 6 e Bt1 do perfil 4, ocorrem hiporevestimentos externos de grãos associados aos blocos subangulares, em quantidades que variam entre 1 e $5 \%$. A apresentam-se com linhas de extinção difusas, indicando que as partículas de argila estão parcialmente orientadas entre si. São feições pedológicas de fábrica (separações plásmicas), resultantes do rearranjo "in situ" do plasma no interior dos agregados, devido a deformações plásticas (Castro, 1989).

Estas deformações plásticas, são induzidas por alternância de ciclos de umedecimento e secamento dos solos, a partir da instalação de fluxo lateral através do entalhamento do relevo (Moniz \& Buol, 1982).

Ocorre que, o aumento do fluxo lateral da solução do solo, além de aumentar o número de ciclos de umedecimento e secamento do solo, também pode favorecer a deposição de argila eluviada, conforme observado por VidalTorrado \& Lepsch (1993), em solos desenvolvidos sobre rochas metamórficas no município de Mococa (SP).

Cabe ressaltar, porém, que pelo fato dos solos aqui estudados serem essencialmente arenosos, o adensamento de partículas, provocado pela alternância dos ciclos de umedecimento e secamento, é pouco pronunciado. Os hiporevestimentos se constituem na principal evidência

Não foram observados, nem morfológica nem micromorfologicamente, variações significativas quanto ao adensamento dos blocos subangulares dos horizontes subsuperficiais em direção ao sopé da vertente. Estes agregados mantém se homogêneos ao longo das topossequências e tanto nos horizontes $\mathrm{Bw}$ quanto nos $\mathrm{Bt}$, não ocorre aumento em dimensão nem em proporção. Exceção ocorre no horizonte Bt2 do perfilP6, que é o horizonte com maior teor 
de argila de todos os perfis das topossequências, onde são observados blocos subangulares de tamanho médio e pedalidade moderadamente desenvolvida, o que confere com a descrição da lâmina, sendo esta, a única lâmina onde a frequência dos blocos subangulares (60\%) supera os microagregados granulares (40\%).

O terceiro grupo envolve as evidências de evento pedogenético, denominado Pedogênese III, cujo principal mecanismo é a degradação dos horizontes latossólicos e texturais. A Pedogênese III pode ser um evento atual e sua continuidade pode levar à latossolização generalizada dos solos situados nesta vertente. As evidências são:

5- Em todas as lâminas analisadas, predomina a trama enáulica em detrimento da trama porfírica, originando porosidade cavitária e de empilhamento (arranjo) dos grão do esqueleto, indicando que pode ter ocorrido perda de argila e concentração residual de areia, sem entretanto ocorrer novo acúmulo da mesma em profundidade ou lateralmente.

6- Todos os solos tem baixa saturação por bases e alta saturação por Al, indicando intemperismo severo sobre estes solos.

Associado à esta degradação dos solos, ocorre a haploidização dos horizontes dos solos pela pedoturbação pela fauna, que pode ser muito intensa em solos bem drenados associados á superfícies antigas (Buol, 1988). Todos os perfis apresentam grandes canais e câmaras até a base das trincheiras, inclusive nos horizontes que foram e estão sendo atingidos pela oscilação do lençol freático.

Finalmente, o quarto grupo de evidências está relacionado ao evento Pedogênese IV e é o processo mais evidente que está ocorrendo nos solos situados no sopé da vertente atualmente. Trata-se da hidromorfia por oscilação do nível freático ao longo dos últimos anos. As evidências são as seguintes:

7- Os perfis P2, P4 e P6, localizados nas porções mais baixas da vertente, apresentam horizontes glei sotopostos aos horizontes texturais, 
caracterizados pela presença de mosqueados e cores acinzentadas, características de zonas onde o ferro foi mobilizado.

8- O nível freático foi atingido à profundidade de $155 \mathrm{~cm}$ no perfil $\mathrm{P} 4$, situado na porção mais baixa da vertente.

9- No perfil P6, são encontrados nódulos milimétricos de ferro e argila, indicando estágio mais evoluído dos processos hidromórficos.

A atuação da Pedogênese IV é restrita ao sopé da vertente, provocando o desmantelamento das estruturas existentes anteriormente, tornando-as maciças. 


\section{CONCLUSÕES}

1- Os solos situados ao longo da vertente constituem um sistema Latossolo - Argissolo, cuja pedogênese foi superposta por processos mais recentes. Esta fase pedogenética anterior, envolveu processos de iluviação de argilas e adensamento por umedecimento e molhamento dos solos, sendo que ambos foram favorecidos pela instalação de fluxos laterais devido ao rebaixamento do nível de base durante a evolução geomorfológica da área. Os

processos pedogenéticos ativos nos solos atualmente são a latossolização e a hidromorfia, sendo a última de ocorrência restrita.

2- A baixa saturação por bases e alta saturação por alumínio no complexo de troca, a mineralogia 1:1 e a predominância de agregados granulares, indicam o alto grau de evolução destes solos.

3- Os solos ao longo da vertente possuem intensa porosidade, caracterizada pelo empilhamento dos grãos do esqueleto quartzoso, amplamente predominante, e pelo arranjo entre os microagregados granulares. A permeabilidade é ainda favorecida pela intensa atuação da mesofauna, propiciando a ação de fluxos gravitacionais importantes.

4- Os solos estudados constituem um sistema frágil, no qual, a disposição de quaisquer tipos de resíduos requer o monitoramento constante de suas propriedades, tanto para a manutenção, quanto para a recuperação da qualidade desta cobertura pedológica. 


\section{REFERÊNCIAS BIBLIOGRÁFICAS}

BOULET, R.; CHAUVEL, R.; LUCAS, Y. Les systèms de transformation em pédologie. In: LIVRE JUBILAIRE DU CINQUANTENAIRE, 1934-1984. Versailles, 1984. Versailles: AFES,1984. p.167-179.

BRASIL. Ministério da Agricultura. Centro Nacional de Ensaio e Pesquisas Agronômicas. Comissão de Solos. Levantamento de Reconhecimento dos Solos do Estado de São Paulo. Rio de Janeiro: Serviço Nacional de Pesquisas Agronômicas, 1960. 634 p.(Boletim, 12).

BREWER, R. Fabric and mineral analysis of soils. New York: Robert E. Krieger Publ., 1976. 482 p.

BULLOCK, P.; FEDOROFF,N.; JONGERIUS, A.; STOOPS, G. \& TURSINA,T. Hanbook for soil thin section description. London: Waine Research, 1985. 152p.

BUOL,S.W.; HOLE,F.D.; Mc CRACKEN,R.J.; SOUTHARD,R.J. Soil genesis and classification. 4ำ ed. Ames: The lowa State University Press, 1997. $527 p$.

CAMERON, K.C.; DI, H.J.; McLAREN, R.G. Is soil na appropriate dumping ground for our wastes?. Australian Journal Soil Research, v.35, p. 9951035, 1997. 
CAMARGO, O.A.; MONIZ, A.C.; JORGE, J.A.; VALADARES, J.M.A.S. Métodos de análise química, mineralógica e física de solos do Instituto Agronômico de Campinas. Campinas: Instituto Agronômico, 1986. 94p. (Boletim Técnico, 106)

CARVALHO, A. Solos da região de Marília: relações entre a pedogênese e a evolução do relevo. São Paulo, 1976. 163p. Tese (Doutorado) - Faculdade de Fisiologia, Letras e Ciências Humanas, Universidade de São Paulo.

CARVER,R.E. Heavy-mineral separation. In: CARVER,R.E. Procedures in sedimentary petrology. Georgia: University of Georgia, 1971.652p.

CASTRO, S.S. de. Sistemas de transformação pedológica em Marília, SP. São Paulo, 1989. 274p. Tese (Doutorado) - Faculdade de Filosofia, Letras e Ciências Humanas, Universidade de São Paulo.

CASTRO, S.S. de. Micromorfologia de solos: pequeno guia para descrição de lâminas delgadas. São Paulo: USP/DG, 1989. 87p. (Compilação organizada com apoio do IPT-DMGA/Petrologia e convênio CAPES x COFECUB, Projeto Pedologia 35/87)

COIMBRA, A.M. Arenitos da Formação Bauru: Estudo de áreas-fonte. São Paulo, 1976. 60p. Dissertação (Mestrado), 2v. Instituto de Geociências, Universidade de São Paulo.

EMPRESA BRASILEIRA DE PESQUISA AGROPECUÁRIA. Centro Nacional de Pesquisa de Solos. Manual de métodos de análise de solo. 2.ed. Rio de Janeiro, 1997. 212p. 
EMPRESA BRASILEIRA DE PESQUISA AGROPECUÁRIA. Centro Nacional de Pesquisa de Solos. Sistema brasileiro de classificação de solos. Rio de Janeiro, 1999. 412p.

ESTADOS UNIDOS. Department of Agriculture. Soil Survey Division. Soil Conservation Service. National Soil Survey Center. Soil survey laboratory information. Lincoln: USDA, 1996. 716p. (Soil Survey Investigations Report, 42)

ESTADOS UNIDOS. Department of Agriculture. Soil Survey Division. Soil Conservation Service. Soil Survey Staff. Soil taxonomy: a basic system of soil classification for making and interpreting soil surveys. 2.ed. Washington: USDA, 1999. 869p. (Agriculture Handbook, 436)

FRITZ,B.; TARDY,Y. Séquences de minéraux secundaries dans l'altération des granites et roches basiques, modèles thermodynamics. Bulletin Sociète Géologie, v.18,n.1, p. 7-12,1976.

FULFARO, V.J.; PERINOTTO, J.A.J. A Bacia Bauru: estado da arte. In: SIMPÓSIO SOBRE O CRETÁCEO DO BRASIL, 4., Rio Claro, 1996. Anais. Rio Claro: UNESP, 1996. v. 1, p. 297-303.

INSTITUTO DE PESQUISAS TECNOLÓGICAS DO ESTADO DE SÃO PAULO. Mapa geológico do Estado de São Paulo. São Paulo, 1981a. 126p. Escala:1:500.000.

INSTITUTO DE PESQUISAS TECNOLÓGICAS DO ESTADO DE SÃO PAULO. Mapa geomorfológico do Estado de São Paulo. São Paulo, 1981b. Escala:1:1.000.000. 
LEMOS, R.C. de; SANTOS, R.D. dos. Manual de descrição e coleta de solos no campo. 2.ed. Campinas: SBCS; SNLCS, 1982. 45 p.

LEPSCH, I.; BUOL, S.W. Investigations in na Oxisol-Ulotisol tposequence in São Paulo State, Brazil. Soil Science Society of America Journal, v.38, p.491-496, 1974.

LEPSCH,I.F.; BUOL,S.W.; DANIELS,R.B. Soil-landscape relationships in the occidental plateau of São Paulo,Brazil: I. Geomorphic surfaces and soil mapping units. Soil Science Society of America Journal, v.41,n.1,p.104109, 1977a.

LEPSCH,I.F.; BUOL,S.W.; DANIELS,R.B. Soil-landscape relationships in the occidental plateau of São Paulo,Brazil: II. Soil morphology, genesis and classification.. Soil Science Society of America Journal, v.41,n.1,p.109115, 1977b.

MASON,B.H. Princípios de geoquímica. São Paulo: Ed. Polígono, 1971. 428p.

MEKARU,T. ; UEHARA,G. Anion adsorption in ferruginous tropical soils. Soil Science Society America Proceedings, v.36,p.296-300, 1972

MELFI,A.J.; PEDRO,G. Estudo geoquímico dos solos e formações superficiais do Brasil. Parte1- Caracterização e repartição dos principais tipos de evolução pedogeoquímica. Revista Brasileira de Geociências, v.7,p.1122,1977 .

MONIZ, A.C. Evolução de conceitos no estudo da gênese de solos. Revista Brasileira de Ciências do Solo, v. 20, p. 349-362, 1996. 
MONIZ, A.C; CARVALHO, A. Seqüência de evolução de solos derivados do arenito Bauru e de rochas básicas do Estado de São Paulo. Bragantia, v.32, n. 17, p. 309-335, 1973.

MONIZ, A.C.; BUOL, S.W. Formation of an Oxisol-Ultisol transition in São Paulo, Brazil: I. Double-water flow model of soil development. Soil Science Society of America Journal, v.46, p 1228-1233, 1982.

MONIZ, A.C.; BUOL, S.W; WEED, S.B. Formation of an Oxisol-Ultisol transition in São Paulo, Brazil: II. Lateral dynamics of chemical weathering. Soil Science Society of America Journal, v.46, p 1234-1239, 1982.

NEMATI, M.R.; CARON, J.; GALLICHAND, J. Stability of structural form during inflitration. Soil Science Society of America Journal, v.64, p 543-552, 2000.

OLIVEIRA,J.B. Solos de Estado de São Paulo: descrição das classes registradas no mapa pedológico. Campinas: Instituto Agronômico, 1999.112 p. (IAC. Boletim Científico, 45).

OLIVEIRA, J.B.; CAMARGO, M. N.; ROSSI, M.; CALDERANO FILHO, B. Mapa pedológico do Estado de São Paulo: legenda expandida. Campinas: Instituto Agronômico; Rio de Janeiro: Embrapa Solos, 1999. 64p.

PESCOD,M.B. Wastewater treatment and use in agriculture. Rome: FAO,1992.125p. (Irrigation and Drainage Paper, 47).

PETRI, S.; FÚLFARO, V.J. Geologia do Brasil. São Paulo: EDUSP, 1983. $631 p$. 
QUEIROZ NETO,J.P.; CASTRO,S.S.; FERNANDES BARROS,O.N.; MANFREDINI,S.; PELLERIN,J.; RUELLAN,A.; TOLEDO,G.S. Um estudo de dinâmica de solos: formação e transformação de perfis com horizonte $B$ textural. In:. CONGRESSO BRASILEIRO DE CIÊNCIA DO SOLO, 18. Resumos. Salvador: Sociedade Brasileira de Ciência do Solo, 1981. P.67

RAIJ,B.van; QUAGGIO,J.A.; CANTARELLA,H.; FERREIRA,M.E.; LOPES,A.S.; BATAGLIA,O.A. Análise de solos para fins de fertilidade. Campinas, Fundação Cargill, 1987. 165 p.

RUEDA, J.R.J.; DEMATTE, J.L.I. Solos originados de lamitos da Formação Marília (Grupo Bauru) da região de Monte Alto, SP. Revista Brasileira de Ciências do Solo, v. 12, p.161-170, 1988.

SOARES, P.C.; LANDIM, P.M.B.; FÚLFARO, V.J.; SOBREIRO NETO, A.F. Ensaio de caracterização estratigráfica do cretáceo no estado de São Paulo: Grupo Bauru. Revista Brasileira de Geociências, v.10, p 177-185, 1980.

VIDAL-TORRADO, P.; LEPSCH, I.F. Morfogênese dos solos de uma toposseqüência com transição $B$ latossólico/B textural sobre migmatitos em Mococa (SP). Revista Brasileira de Ciências do Solo, v. 17, n. 1, p.109119, 1993.

VIDAL-TORRADO, P.; LEPSCH, I.F.; CASTRO, S.S; COOPER, M. Pedogênese em uma seqüência latossolo-podzólico na borda de um platô na depressão periférica paulista. Revista Brasileira de Ciências do Solo, v. 23, p.909921, 1999. 
YU, T.R. Chemistry of variable charge soils. New York: Oxford University Press, 1997.505p. 
APÊNDICES 
APÊNDICE 1: DESCRIÇÕES MORFOLÓGICAS DOS PERFIS DAS TOPOSSEQUÊNCIAS A e B 


\section{Perfil P1: LATOSSOLO VERMELHO Distrófico típico}

Ap $\quad 0-12 \mathrm{~cm}$, bruno avermelhado escuro (2,5YR 3/3, úmida); franco-arenoso; fraca, média, grumosa; ligeiramente duro, muito friável, não plástico e não pegajoso; transição abrupta e ondulada.

BA 12-30cm, vermelho escuro a vermelho muito escuro (2,5YR 3,5/6, úmido); franco-arenoso; moderada, média a pequena, blocos subangulares que se desfaz em moderada, pequena, granular; ligeiramente duro, friável, não plástico e não pegajoso; transição clara e plana.

$\mathrm{Bw}_{1}$ 30-90cm, vermelho (2,5YR 4/6, úmida); franco-arenoso; fraca a moderada, média a pequena, blocos subangulares que se desfaz em moderada, pequena, granular; ligeiramente duro, firme, não plástico e não pegajoso; transição clara e plana.

$\mathrm{Bw}_{2}$ 90-200cm, vermelho (2,5YR 4/7, úmido); franco-arenoso; fraca, pequena, blocos subangulares ; ligeiramente duro, friável, não plástico e não pegajoso.

Obs: Muitos poros pequenos e grandes em todo o perfil; muitas raízes até $110 \mathrm{~cm}$, diminuindo para a base do perfil. De 12 a $25 \mathrm{~cm}$ horizonte rico em carvão. Muita areia lavada a partir de $30 \mathrm{~cm}$. De $33-90 \mathrm{~cm}$, muitas câmaras e canais da mesofauna.

\section{Perfil P2: ARGISSOLO VERMELHO-AMARELO Distrófico latossólico}

Ap $0-10 \mathrm{~cm}$, bruno avermelhado escuro (5YR 3/4, úmido); franco-arenoso; fraca, pequena, grumosa; macio, solto, não plástico e não pegajoso; transição abrupta e plana.

BA $10-35 \mathrm{~cm}$, bruno avermelhado (5YR 4/4, úmido); franco-argilo-arenoso; fraca, pequena, blocos subangulares á maciça porosa; solto, muito friável, ligeiramente plástico e não pegajoso; transição gradual e plana.

$\mathrm{Bt}_{1} \quad 35-75 \mathrm{~cm}$, bruno avermelhado (5YR 4/4, úmido); franco-argilo-arenoso; fraca pequena, blocos subangulares que se desfaz em moderada, pequena, 
agregados granulares; ligeiramente duro, firme, liogeiramente plástico e ligeiramente pegajoso; transição gradual e plana.

$\mathrm{Bt}_{2} \quad 75-120 \mathrm{~cm}$, vermelho amarelado (5YR 5/6, úmido); franco-argilo-arenoso; fraca, pequena, blocos subangulares; ligeiramente duro, muito friável, não plástico e não pegajoso; transição gradual e plana.

$\mathrm{Bt}_{3}$ 120-210cm, vermelho amarelado (5YR 5/6, úmido); franco-argiloarenoso; fraca, pequena, blocos subangulares; ligeiramente duro, friável, não plástico e não pegajoso; transição gradual e plana.

Btg 210-250cm, vermelho amarelado (5YR 4/6, úmido) mosqueado comum, pequeno a médio e distinto cinzento rosado (5YR 6/2, úmido); franco-argiloarenoso; fraca, pequena, blocos subangulares; ligeiramente duro, friável, não plástico e não pegajoso.

Obs: Muita matéria orgânica até $20 \mathrm{~cm}$. De $35-75 \mathrm{~cm}$, horizonte muito compacto. Ocorrência intensa de areia lavada até $75 \mathrm{~cm}$, diminuindo até $120 \mathrm{~cm}$. Abaixo de $120 \mathrm{~cm}$, os horizontes tornam-se pouco drenados em contraste com os horizontes sobrejacentes, muito porosos e bem drenados.

\section{Perfil P3: LATOSSOLO VERMELHO Distrófico típico}

Ap 0-5cm, bruno avermelhado escuro (5YR 3/4, úmido); franco-arenoso; fraca, pequena, grumosa; solta , muito friável, não plástico e não pegajoso; transição clara e plana.

AB 5-20cm, vermelho escuro (2,5YR 3/6, úmido); franco-arenoso; fraca, pequena, blocos subangulares; macio, friável, não plástico e não pegajoso; transição clara e plana.

$\mathrm{Bw}_{1} \quad 20-50 \mathrm{~cm}$, bruno avermelhado (2,5YR 4/4, úmido); franco-argilo-arenoso; fraca, pequena a média, blocos subangulares; ligeiramente duro, muito friável, ligeiramente plástico e ligeiramente pegajoso; transição clara e plana. 
$\mathrm{Bw}_{2} \quad 50-100 \mathrm{~cm}$, vermelho (2,5YR 4/6, úmido); franco-argilo-arenoso; moderada a fraca, média, blocos subangulares; duro, friável, ligeiramente plástico e não pegajoso; transição clara e plana.

$\mathrm{Bw}_{3}$ 100-170cm, vermelho (2,5YR 4/6, úmido); franco-argilo-arenoso; moderada, pequena a média, blocos subangulares; duro, friável, ligeiramente plástico e não pegajoso; transição clara e plana.

$\mathrm{Bw}_{4}$ 170-210cm, vermelho (2,5YR 4/6, úmido); franco-arenoso; moderada, média, blocos subangulares; duro, friável, ligeiramente plástico e não pegajoso; transição clara e plana.

$\mathrm{Bw}_{5}$ 210-230cm, vermelho (2,5YR 4/6, úmido); franco-arenoso; fraca, média, blocos subangulares; ligeiramente duro, muito friável, ligeiramente plástico e não pegajoso.

Obs: Perfil muito úmido até $50 \mathrm{~cm}$. Muita areia lavada a partir de $20 \mathrm{~cm}$, aumentando a $170 \mathrm{~cm}$ e formando bandas de espessuras milimétricas e descontínuas a partir de $210 \mathrm{~cm}$. Muitos poros pequenos, médios e grandes, diminuindo a partir de $170 \mathrm{~cm}$. Muitas raízes até $170 \mathrm{~cm}$, tornando-se raras.. Intensa atividade biológica com canais e câmaras até $170 \mathrm{~cm}$. Carvão entre 50 e $100 \mathrm{~cm}$.

\section{Perfil P4: ARGISSOLO AMARELO Distrófico abrúptico}

Ap $\quad 0-7 \mathrm{~cm}$, bruno avermelhado escuro (5YR 3/2, úmido); franco-arenoso; fraca, pequena, grumosa; macio, solto, não plástico e não pegajoso; transição clara e plana.

AB 7-23cm, cinza avermelhado escuro (5YR 4/2, úmido) mosqueado pouco, pequeno e distinto, cinza avermelhado (5YR 5/2, úmido); franco-arenoso; fraca, pequena, grumosa; solto, solto, não plástico e não pegajoso; transição clara e ondulada. 
$\mathrm{Bt}_{1} \quad 23-57 \mathrm{~cm}$, bruno avermelhado (5YR 5/3, úmido); franco-argilo-arenoso; fraca, pequena, blocos subangulares a maciça; solto, muito friável, não plástico e não pegajoso; transição clara e ondulada.

$\mathrm{Bt}_{2}$ 57-94cm, bruno avermelhado claro (5YR 6/5, úmido) mosqueado pouco, pequeno e distinto amarelo avermelhado (5YR 6/4, úmido); franco-argiloarenoso; fraca, pequena, blocos subangulares; solto, friável, não plástico e não pegajoso; transição gradual e ondulada.

Btg 94-155cm, cinza claro (10YR 7/2, úmido) mosqueado abundante, médio e distinto bruno avermelhado claro (5YR 6/5, úmido); franco-argilo-arenoso; maciça; macio, friável, ; não plástico e não pegajoso.

Obs: Perfil muito úmido. Muitos poros grandes e médios em todo o perfil. Poucas raízes. A partir de $57 \mathrm{~cm}$ sinais de hidromorfia, caracterizado por manchas claras ao longo das raízes e na parede dos poros grandes. Nível estático do lençol freático a $155 \mathrm{~cm}$.

\section{Perfil P5: ARGISSOLO VERMELHO Distrófico latossólico}

Ap $\quad 0-5 \mathrm{~cm}$, bruno avermelhado escuro (5YR 3/4, úmido); franco-arenoso; fraca, pequena, grumosa; solto, muito friável, não plástico e não pegajoso; transição abrupta e plana..

$A B \quad 5-12 \mathrm{~cm}$, bruno avermelhado (2,5YR 3/4, úmido); franco-arenoso; fraca, pequena, blocos subangulares; solto, muito friável, não plástico e não pegajoso; transição gradual e plana.

BA $12-56 \mathrm{~cm}$, vermelho escuro (2,5YR $3 / 6$, úmido); franco-argilo-arenoso; fraca, pequena a média, blocos subangulares; macio, friável, não plástico e não pegajoso; transição clara e plana.

$\mathrm{Bt}_{1} \quad 56-120 \mathrm{~cm}$, vermelho (2,5YR 4/6, úmido); franco-argilo-arenoso; moderada a fraca, média, blocos subangulares; ligeiramente duro, firme, ligeiramente plástico e não pegajoso; transição clara e plana. 
$\mathrm{Bt}_{2}$ 120-160cm, vermelho (2,5YR 4/6, úmido); franco-argilo-arenoso; moderada a fraca, pequena a média, blocos subangulares; ligeiramente duro, firme, ligeiramente plástico e ligeiramente pegajoso; transição clara e plana.

$\mathrm{Bt}_{3}$ 160-200cm, vermelho (2,5YR 4/6, úmido); franco-argilo-arenoso; fraca, pequena, blocos subangulares; ligeiramente duro, firme, não plástico e não pegajoso; transição clara e plana.

Bw 200-220cm, vermelho (2,5YR 4/6, úmido); franco-argilo-arenoso; fraca, pequena a média, blocos subangulares que se desfazem em agregados granulares; ligeiramente duro, friável, não plástico e não pegajoso.

Obs: Perfil muito úmido até $56 \mathrm{~cm}$. Muitos poros pequenos, médios e grandes. Muitas raízes até $56 \mathrm{~cm}$, tornando-se escassas. Intensa atividade biológica até $170 \mathrm{~cm}$, mais intensamente entre 12 e $56 \mathrm{~cm}$, com câmaras decimétricas. Grande ocorrência de areia lavada a partir de $56 \mathrm{~cm}$, aumentando a partir de $160 \mathrm{~cm}$.

\section{Perfil P6: ARGISSOLO VERMELHO Distrófico abrúptico}

A $\quad 0-7 \mathrm{~cm}$, bruno avermelhado escuro (5YR 3/4, úmido); franco-arenoso; fraca, pequena, grumosa; solto, muito friável, não plástico e não pegajoso; transição clara e plana.

AB 7-17cm, bruno avermelhado (2,5YR 4/4, úmido); franco-arenoso; fraca, pequena, blocos subangulares; macio, friável, não plástico e não pegajoso; transição clara e ondulada.

$\mathrm{Bt}_{1}$ 17-50cm, vermelho (2,5YR 4/6, úmido); franco-argilo-arenoso; moderada a fraca, média, blocos subangulares que se rompem em blocos menores; ligeiramente duro, friável, ligeiramente plástico e ligeiramente pegajoso; clara e ondulada.

$\mathrm{Bt}_{2} \quad 50-90 \mathrm{~cm}$, vermelho (2,5YR 4/6, úmido); franco-argiloso-arenoso; moderada, média, blocos subangulares; ligeiramente duro, firme, ligeiramente plástico e ligeiramente pegajoso; transição clara e plana. 
$\mathrm{Bt}_{3}$ 90-165cm, vermelho amarelado (5YR 5/6, úmido); franco-argilo-arenoso; fraca, pequena, blocos subangulares; ligeiramente duro, friável, ligeiramente plástico e ligeiramente pegajoso; transição clara e plana.

$\mathrm{Bt}_{4} \quad 165-205 \mathrm{~cm}$, vermelho (2,5YR 4/8, úmido); franco-argilo-arenoso; fraca, pequena, blocos subangulares; ligeiramente duro, firme, ligeiramente plástico e não pegajoso; transição clara e ondulada.

Btg 205-240cm, vermelho (2,5YR 4/8, úmido) mosqueado abundante, médio, distinto, cinzento rosado (5YR 6/2); franco-argilo-arenoso; maciça; macio, friável, ligeiramente plástico e não pegajoso.

Obs: Perfil muito úmido até $50 \mathrm{~cm}$. Muita matéria orgânica na parte superior. Traços de carvão entre 17 e 50cm.Grandes ortotúbulos entre 90 e $165 \mathrm{~cm}$. Sinais de hidromorfia (manchas cinza claro) ocorrem entre 165 e $205 \mathrm{~cm}$. Níveis de concreções escuras pouco duras (cortam-se com canivete) com núcleo arenoso á 90 e $240 \mathrm{~cm}$. As raízes ocorrem até $100 \mathrm{~cm}$. Muitos poros pequenos e médios em todo o perfil. 


\section{APÊNDICE 2}

DESCRIÇÕES MICROMORFOLÓGICAS DOS PERFIS DAS

TOPOSSEQUÊNCIAS A e B 
PERFIL 1 - LATOSSOLO VERMELHO Distrófico típico

\begin{tabular}{|c|c|c|c|}
\hline Atrib./horiz. & BA (18-28) & Bw1 (62-72) & Bw2(130-140) \\
\hline $\begin{array}{l}\text { Micro- } \\
\text { estrutura e } \\
\text { respectivos } \\
\text { tipos de } \\
\text { agregados }\end{array}$ & $\begin{array}{l}\text { Microagregados intergra } \\
\text { nulares }(70 \%), \mathrm{c} / \text { agregados } \\
\text { granulares ultra-finos } \\
\text {.Blocos sub-angulares ( } 30 \%)(0,8 \text { a } \\
1,2 \mathrm{~mm}) \text { delimitados por porosi } \\
\text { dade de empilhamento. }\end{array}$ & $\begin{array}{l}\text { Microagregados intergra } \\
\text { nulares }(70 \%) \text {, c/ agregados } \\
\text { granulares ultra-finos. } \\
\text {.Blocos sub-angulares ( } 30 \%)(0,4 \text { a } \\
1,2 \mathrm{~mm}) \text { delimitados por porosi } \\
\text { dade de empilhamento. }\end{array}$ & $\begin{array}{l}\text { Microagregados intergra } \\
\text { nulares }(80 \%) \text {, c/ agregados } \\
\text { granulares ultra-finos. } \\
\text {.Blocos sub-angulares ( } 20 \%) \\
\text { (0,3 a } 0,8 \mathrm{~mm}) \text { delimitados por } \\
\text { porosidade de empilhamento }\end{array}$ \\
\hline Plasma & $\begin{array}{l}20 \% \text { orientação estriada } \\
\text { (granoestriada) e manchada } \\
\text { (salpicada grânica e em mosaico) }\end{array}$ & $\begin{array}{l}\text { 15\% orientação estriada } \\
\text { (granoestriada) e manchada } \\
\text { (salpicada grânica e em mosaico) }\end{array}$ & $\begin{array}{l}10 \% \text { orientação estriada } \\
\text { (granoestriada) e manchada } \\
\text { (salpicada grânica e em } \\
\text { mosaico)) }\end{array}$ \\
\hline Esqueleto & $\begin{array}{l}40 \% \text {-de } 0,08 \text { a 0,3mm, predomínio } \\
\text { de } 0,15 \mathrm{~mm} \text { (areia fina), anedrais, } \\
\text { bem selecionados, subarred. mod. } \\
\text { esféricos, lisos, contrastes distintos, } \\
\text { nítidos, variabilidade baixa. }\end{array}$ & $\begin{array}{l}35 \% \text { de } 0,08 \text { a 0,3mm, predomínio } \\
\text { de } 0,15 \mathrm{~mm} \text { (areia fina), anedrais, } \\
\text { bem selecionados, subarred. mod. } \\
\text { esféricos, lisos, contrastes distintos, } \\
\text { nítidos, variabilidade baixa. }\end{array}$ & $\begin{array}{l}30 \% \text { de } 0,05 \text { a } 0,4 \mathrm{~mm} \mathrm{c} / \\
\text { predomínio de } 0,18 \mathrm{~mm} \text { (areia } \\
\text { fina) anedrais, bem } \\
\text { selecionados, subarred. mod. } \\
\text { Esféricos, lisos, contrastes } \\
\text { distintos, nítidos, variabilidade } \\
\text { baixa. }\end{array}$ \\
\hline Poros & $\begin{array}{l}40 \% \\
\text { interagregada: empilhamento } \\
(40 \%) \text {, cavitária }(25 \%)(0,2 \text { a } 0,6 \\
\text { mm), canais ( } 8 \%)(1,0 \text { a } 5,0 \mathrm{~mm}) \text { e } \\
\text { câmaras }(5 \%) \text { (até } 15 \mathrm{~mm}) \text {. } \\
\text { Intragregada: microporosidade } \\
\text { cavitária (20\%) (média 0,1 mm) e } \\
\text { fissural }(2 \%)\end{array}$ & $\begin{array}{l}50 \% \\
\text { interagregada: empilhamento } \\
(50 \%) \text {, cavitária (30\%) (0,5 a 2,0 } \\
\text { mm), canais ( } 8 \% \text { ) (2 a } 8 \mathrm{~mm}) \text { e } \\
\text { câmaras (2\%) (de } 10 \text { a } 15 \mathrm{~mm}) \text {. } \\
\text { Intragregada: microporosidade } \\
\text { cavitária (8\%) (média 0,1 mm) e } \\
\text { fissural }(2 \%)\end{array}$ & $\begin{array}{l}60 \% \\
\text { interagregada: empilhamento } \\
(50 \%) \text {, cavitária }(30 \%)(0,2 \text { a } \\
0,5 \mathrm{~mm}) \text {, canais }(5 \%)(2 \text { a } 6 \\
\text { mm) } \\
\text { Intragregada: microporosidade } \\
\text { cavitária }(8 \%) \text { (média } 0,02 \mathrm{~mm}) \\
\text { e fissural }(2 \%)\end{array}$ \\
\hline Trama & $\begin{array}{l}\text { Enáulica-70\% } \\
\text { Porfírica-30\% }\end{array}$ & $\begin{array}{l}\text { Enáulica-70\% } \\
\text { Porfírica-30\% }\end{array}$ & $\begin{array}{l}\text { Enáulica-80\% } \\
\text { Porfírica-20\% }\end{array}$ \\
\hline Feições & Ortotúbulos milimétricos & Ortotúbulos milimétricos & Ortotúbulos milimétricos \\
\hline
\end{tabular}


PERFIL 2 - ARGISSOLO VERMELHO - AMARELO Distrófico latossólico

\begin{tabular}{|c|c|c|c|c|c|}
\hline $\begin{array}{l}\text { Atrib./ } \\
\text { horiz }\end{array}$ & BA (25-35) & Bt1 (47-57) & Bt2 (85-95) & Bt3 (135-145) & Btg (217-227) \\
\hline $\begin{array}{c}\text { Micro- } \\
\text { estrut } \\
\text { ura }\end{array}$ & $\begin{array}{l}\text { microagregados intergra } \\
\text { nulares }(85 \%), \mathrm{c} / \\
\text { agregados granulares } \\
\text { ultra-finos) } \\
\text { blocos sub-angulares } \\
(15 \%)(0,8 \text { a } 2,5 \mathrm{~mm}\end{array}$ & $\begin{array}{l}\text { Microagregados } \\
\text { intergra } \\
\text { nulares }(90 \%) . c / \\
\text { agregados } \\
\text { granulares ultra- } \\
\text { finos. } \\
\text { Blocos sub- } \\
\text { angulares) }(10 \%) \\
(0,15 \text { a } 1,0 \mathrm{~mm})\end{array}$ & $\begin{array}{l}\text { Microagregados } \\
\text { intergranulares }(90 \%) \\
\text { c/ agregados } \\
\text { granulares ultra-finos. } \\
\text { Blocos sub-angulares } \\
(10 \%)(0,1 \text { a } 0,4 \mathrm{~mm})\end{array}$ & $\begin{array}{l}\text { Microagregados } \\
\text { intergranulares ( } 80 \%) \\
\text { e blocos } \\
\text { subangulares }(20 \%) \\
(0,1 \text { a } 0,3 \mathrm{~mm})\end{array}$ & $\begin{array}{l}\text { Microagregados } \\
\text { intergranulares } \\
(95 \%) \text { e blocos } \\
\text { subangulares }(5 \%) \\
(0,2 \text { a } 0,3 \mathrm{~mm})\end{array}$ \\
\hline $\begin{array}{c}\text { Plasm } \\
\text { a e } \\
\text { orient } \\
\text { a } \\
\text { ções } \\
\text { plásm } \\
\text { icas }\end{array}$ & $\begin{array}{l}20 \% \\
\text { orientação estriada } \\
\text { (granoestriada) e } \\
\text { manchada (salpicada } \\
\text { grânica e em mosaico }\end{array}$ & $\begin{array}{l}40 \% \\
\text { orientação estriada } \\
\text { (granoestriada) e } \\
\text { manchada } \\
\text { (salpicada grânica e } \\
\text { em mosaico }\end{array}$ & $\begin{array}{l}30 \% \\
\text { orientação estriada } \\
\text { (granoestriada) e } \\
\text { manchada (salpicada } \\
\text { grânica e em mosaico }\end{array}$ & $\begin{array}{l}20 \% \\
\text { orientação estriada } \\
\text { (granoestriada) e } \\
\text { manchada (salpicada } \\
\text { grânica e em } \\
\text { mosaico }\end{array}$ & $\begin{array}{l}20 \% \\
\text { orientação estriada } \\
\text { (granoestriada) e } \\
\text { manchada } \\
\text { (salpicada grânica } \\
\text { e em mosaico }\end{array}$ \\
\hline $\begin{array}{l}\text { Esque } \\
\text { leto }\end{array}$ & $\begin{array}{l}30 \% \text {-de } 0,0830,3 \mathrm{~mm} \text {, } \\
\text { predomínio de } 0,15 \mathrm{~mm} \\
\text { (areia fina), subarred., } \\
\text { moder. esfér. , anedrais }\end{array}$ & $\begin{array}{l}30 \% \\
\text { de } 0,05 \text { a } 0,3 \mathrm{~mm} \mathrm{c} / \\
\text { predom/inio de } 0,15 \\
\mathrm{~mm} \text { (areia fina) }\end{array}$ & $\begin{array}{l}30 \% \\
\text { de } 0,05 \text { a } 0,4 \mathrm{~mm} \mathrm{c} / \\
\text { predomínio de } 0,18 \mathrm{~mm} \\
\text { (areia fina) }\end{array}$ & $\begin{array}{l}30 \% \\
\text { de } 0,0,5 \text { a } 0,3 \mathrm{~mm} \mathrm{c/} \\
\text { predomínio de } 0,16 \\
\mathrm{~mm} \text { (areia fina) }\end{array}$ & $30 \%$ \\
\hline Poros & $\begin{array}{l}50 \% \\
\text { Interagregados: } \\
\text { empilhamento (40\%), } \\
\text { cavitária }(20 \%) \text { e canais } \\
(10 \%) \\
\text { Intragregada : } \\
\text { Microporosidade fissural } \\
(10 \%) \text { e } \\
\text { mesoporosidade } \\
\text { cavitária }(20 \%)\end{array}$ & $\begin{array}{l}30 \% \\
\text { interagregados: } \\
\text { de empilhamento } \\
(30 \%), \\
\text { cavitária }(50 \%) \\
\text { (média } 0,3 \mathrm{~mm} \text { e } \\
\text { canais }(10 \%) \text { (2 a } 3 \\
\text { mm) } \\
\text { Intragregada: } \\
\text { mesoporosidade } \\
\text { cavitária } \\
(6 \%) \text { e fissural }(4 \%)\end{array}$ & $\begin{array}{l}40 \% \\
\text { interagregada } \\
\text { de empilhamento } \\
(30 \%) \text {, cavitária }(50 \%) \\
\text { (média } 0,15 \mathrm{~mm}) \mathrm{e} \\
\text { canais }(10 \%) \\
\text { Intragregada } \\
\text { mesoporosidade } \\
\text { cavitária }(5 \%) \text { e fissural } \\
(5 \%)\end{array}$ & $\begin{array}{l}50 \% \\
\text { interagregada : } \\
\text { empilhamento }(50 \%) \\
\text { cavitária }(30 \%)(0,1 \\
\text { a 0,8 mm c/ } \\
\text { predomínio de } 0,15 \\
\text { mm) e canais }(10 \%) \\
\text { intragregada } \\
\text { cavitária (8\%) }(0,05 \text { a } \\
0,5 \mathrm{~mm}) \text { e fissural } \\
(2 \%)\end{array}$ & $\begin{array}{l}50 \% \\
\text { interagregada } \\
\text { empilhamento } \\
(55 \%) \text { cavitária } \\
(30 \%) \text { (média } 0,3 \\
\mathrm{~mm}) \text { e canais } \\
(10 \%)(1,0 \text { a } 2,0 \\
\mathrm{mm}) \\
\text { intragregada } \\
\text { cavitários }(2 \%) \\
(0,03 \text { a } 0,07 \mathrm{~mm}) \text { e } \\
\text { microporos } \\
\text { fissurais }(3 \%)\end{array}$ \\
\hline Trama & $\begin{array}{l}\text { Enáulica-85\% } \\
\text { Porfírica 15\% }\end{array}$ & $\begin{array}{l}\text { Enáulica-90\% } \\
\text { Porfírica 10\% }\end{array}$ & $\begin{array}{l}\text { Enáulica-90\% } \\
\text { Porfírica 10\% }\end{array}$ & $\begin{array}{l}\text { Enáulica } 80 \% \\
\text { Porfírica 20\% }\end{array}$ & $\begin{array}{l}\text { Enáulica 95\% } \\
\text { Porfírica 5\% }\end{array}$ \\
\hline $\begin{array}{c}\text { Feiçõ } \\
\text { es }\end{array}$ & Ortotúbulos & $\begin{array}{l}\text { Zona de } \\
\text { revestimentos na } \\
\text { parte superior da } \\
\text { lâmina,peenchendo } \\
\text { a porosidade de } \\
\text { empilhamento. }\end{array}$ & Grandes ortotúbulos. & & \\
\hline
\end{tabular}


PERFIL 3 - LATOSSOLO VERMELHO Distrófico típico

\begin{tabular}{|c|c|c|c|c|}
\hline Atrib./horiz. & Bw2 (80-90) & Bw3 (130-140) & Bw4 (180-190) & Bw5 (214-224) \\
\hline $\begin{array}{l}\text { Micro- } \\
\text { estrutura }\end{array}$ & $\begin{array}{l}\text { Microagregados intergra } \\
\text { nulares }(80 \%) \mathrm{c} / \\
\text { agregados granulares } \\
\text { ultra-finos } \\
\text { blocos sub-angulares } \\
(20 \%)(0,3 \text { a } 0,8 \text { e } 2,5 \\
\mathrm{mm})\end{array}$ & $\begin{array}{l}\text { Microagregados intergra } \\
\text { nulares }(85 \%) \mathrm{c} / \\
\text { agregados granulares } \\
\text { ultra-finos. } \\
\text { Blocos sub-angulares } \\
(0,15 \text { a } 1,0 \mathrm{~mm})(15 \%)\end{array}$ & $\begin{array}{l}\text { Microagregados } \\
\text { intergranulares }(92 \%) . c / \\
\text { agregados granulares } \\
\text { ultra-finos } \\
\text { Blocos sub-angulares } \\
\text { (média de } 0,1 \mathrm{~mm} \text { ) }(8 \%)\end{array}$ & $\begin{array}{l}\text { Microagregados } \\
\text { intergranulares }(90 \%), \text { e } \\
\text { blocos subangulares } \\
(10 \%)(0,2 \text { a } 0,4 \mathrm{~mm} \text { e } \\
1,0 \mathrm{~mm})\end{array}$ \\
\hline $\begin{array}{c}\text { Plasmae } \\
\text { orientações } \\
\text { plásmicas }\end{array}$ & $\begin{array}{l}15 \% \\
\text { orientação estriada } \\
\text { (granoestriada) e } \\
\text { manchada (salpicada } \\
\text { grânica e em mosaico) } \\
\text { vermelho, argila e óxidos } \\
\text { de Fe }\end{array}$ & $\begin{array}{l}15 \% \\
\text { orientação estriada } \\
\text { (granoestriada) e } \\
\text { manchada (salpicada } \\
\text { grânica e em mosaico) } \\
\text { vermelho, argila e óxidos } \\
\text { de Fe }\end{array}$ & $\begin{array}{l}15 \% \\
\text { orientação estriada } \\
\text { (granoestriada) e } \\
\text { manchada (salpicada } \\
\text { grânica e em mosaico) } \\
\text { vermelho, argila e óxidos } \\
\text { de Fe }\end{array}$ & $\begin{array}{l}10 \% \\
\text { orientação estriada } \\
\text { (granoestriada) e } \\
\text { manchada (salpicada } \\
\text { grânica e em mosaico) } \\
\text { vermelho, argila e óxidos } \\
\text { de Fe }\end{array}$ \\
\hline Esqueleto & $\begin{array}{l}45 \% \text {-de } 0,0830,3 \mathrm{~mm} \text {, } \\
\text { predomínio de } 0,15 \mathrm{~mm} \\
\text { (areia fina), subarred., } \\
\text { moder. esfér. , anedrais }\end{array}$ & $\begin{array}{l}45 \% \\
\text { de } 0,05 \text { a } 0,3 \mathrm{~mm} \mathrm{c} / \\
\text { predominio de } 0,15 \mathrm{~mm} \\
\text { (areia fina) }\end{array}$ & $\begin{array}{l}45 \% \\
\text { de } 0,05 \text { a } 0,4 \mathrm{~mm} \mathrm{c} / \\
\text { predomínio de } 0,18 \mathrm{~mm} \\
\text { (areia fina) }\end{array}$ & $\begin{array}{l}50 \% \\
\text { de } 0,0,5 \text { a } 0,3 \mathrm{~mm} \mathrm{c/} \\
\text { predomínio de } 0,16 \mathrm{~mm} \\
\text { (areia fina) }\end{array}$ \\
\hline Poros & $\begin{array}{l}40 \% \\
\text { Interagregada } \\
\text { empilhamento }(40 \%), \\
\text { cavitária }(20 \%)(0,08 \text { a } \\
0,3 \mathrm{~mm}) \text { e canais }(20 \%) \\
\text { (entre } 0,6 \text { e } 2,5 \mathrm{~mm}) \\
\text { Intragregada }(10 \%): \\
\text { Microporos fissurais } \\
(8 \%) \text { e mesoporos } \\
\text { cavitários }(2 \%) \\
(\sim 0,05 \mathrm{~mm}) \\
\end{array}$ & $\begin{array}{l}40 \% \\
\text { interagregada } \\
\text { empilhamento (20\%), } \\
\text { cavitária(50\%) (média } \\
0,3 \mathrm{~mm}) \text { e canais (2 a } \\
10 \mathrm{~mm})(10 \%) \\
\text { Intragregada: } \\
\text { mesoporosidade } \\
\text { cavitária } \\
(8 \%) \text { e fissural (2\%) }\end{array}$ & $\begin{array}{l}40 \% \\
\text { interagregada } \\
\text { macroporosidade de } \\
\text { empilhamento ( } 30 \%) \text {, } \\
\text { cavitária }(57 \%) \text { (média } \\
0,3 \mathrm{~mm}) \text { e canais }(10 \%) \\
2 \text { a } 10 \mathrm{~mm} \\
\text { Intragregada } \\
\text { mesoporosidade } \\
\text { cavitária }(1 \%) \text { e fissural } \\
(2 \%)\end{array}$ & \begin{tabular}{|l|}
$40 \%$ \\
interagregada \\
empilhamento ( $30 \%)$ \\
cavitária $(50 \%)(0,1$ a \\
$0,4 \mathrm{~mm} \mathrm{c} /$ predomínio de \\
$0,15 \mathrm{~mm})$ e canais $(10 \%)$ \\
$(1$ a $5 \mathrm{~mm})$ \\
intragregada \\
cavitária (5\%) $(0,05$ a 0,5 \\
mm-e fissural (5\%)
\end{tabular} \\
\hline Trama & $\begin{array}{l}\text { Enáulica }(80 \%) \\
\text { Porfírica }(20 \%)\end{array}$ & $\begin{array}{l}\text { Enáulica85\% } \\
\text { Porfírica 15\% }\end{array}$ & $\begin{array}{l}\text { Enáulica-92\% } \\
\text { Porfírica } 8 \%\end{array}$ & $\begin{array}{l}\text { Enáulica (90\%) } \\
\text { Porfírica (10\%) }\end{array}$ \\
\hline Feições & $\begin{array}{l}\text { Ortotúbulos de } 0,6 \text { a 2,5 } \\
\text { mm }\end{array}$ & & Grandes ortotúbulos. & $\begin{array}{l}\text { Ortotúbulos milimétricos } \\
\text { (até } 2 \mathrm{~mm} \text { ) }\end{array}$ \\
\hline
\end{tabular}


Perfil 4 - ARGISSOLO AMARELO Distrófico abrúptico

\begin{tabular}{|c|c|c|c|}
\hline Atrib./horiz. & Bt1 (44-54) & Bt2 (65-75) & Btg (125-135) \\
\hline $\begin{array}{c}\text { Micro- } \\
\text { estrutura }\end{array}$ & $\begin{array}{l}\text { Microagregados intergra } \\
\text { nulares }(70 \%) \mathrm{c} / \text { agregados } \\
\text { granulares ultra-finos } \\
\text { blocos sub-angulares (30\%) }\end{array}$ & $\begin{array}{l}\text { Microagregados intergra } \\
\text { nulares }(85 \%) \text { c/ agregados } \\
\text { granulares ultra-finos. } \\
\text { Blocos sub-angulares (15\%) }(0,4 \\
\text { a1,0mm) }\end{array}$ & $\begin{array}{l}\text { Microagregados intergra } \\
\text { nulares }(85 \%) \text { c/ agregados } \\
\text { granulares ultra-finos. } \\
\text { Blocos sub-angulares (15\%) }(0,4 \\
\text { a1,0mm) }\end{array}$ \\
\hline Plasma & $\begin{array}{l}30 \% \\
\text { vermelho, argila eóxidos de Fe }\end{array}$ & $\begin{array}{l}15 \% \\
\text { vermelho, salpicado granido, }\end{array}$ & $\begin{array}{l}15 \% \\
\text { vermelho, salpicado granido }\end{array}$ \\
\hline Esqueleto & $\begin{array}{l}45 \% \text {-de } 0,0830,3 \mathrm{~mm} \text {, } \\
\text { predomínio de } 0,15 \mathrm{~mm} \text { (areia } \\
\text { fina), subarred., moder. esfér. , } \\
\text { anedrais }\end{array}$ & $\begin{array}{l}45 \% \\
\text { de } 0,05 \text { a } 0,3 \mathrm{~mm} \mathrm{c} / \text { predom/inio } \\
\text { de } 0,15 \mathrm{~mm} \text { (areia fina) }\end{array}$ & $\begin{array}{l}\text { de } 0,05 \text { a 0,4 mm c/ predomínio } \\
\text { de } 0,18 \mathrm{~mm} \text { (areia fina) }\end{array}$ \\
\hline Poros & $\begin{array}{l}40 \% \\
\text { Interagregada } \\
\text { Empilhamento (30\%), cavitária } \\
(55 \%) \text { (predominan 0,08 e 0,6 } \\
\text { mm) e canais (10\%) } \\
\text { Intragregada : } \\
\text { Microporos fissurais }(3 \%) \text { e } \\
\text { mesoporos cavitários }(2 \%)\end{array}$ & $\begin{array}{l}40 \% \text { interagregada } \\
\text { empilhamento }(20 \%) \text {, cavitária } \\
(60 \%)(0,1 \text { a } 1,0 \mathrm{~mm}) \text { e canais } \\
(10 \%) \\
\text { Intragregada: } \\
\text { mesoporosidade cavitária } \\
(8 \%) \text { e fissural }(2 \%)\end{array}$ & $\begin{array}{l}40 \% \\
\text { interagregada } \\
\text { macroporosidade de } \\
\text { empilhamento }(30 \%) \text {, cavitária } \\
(52 \%) \text { (média } 0,3 \mathrm{~mm}) \text { e canais } \\
(10 \%) \\
\text { Intragregada } \\
\text { mesoporosidade cavitária (5\%) } \\
\text { e fissural }(3 \%)\end{array}$ \\
\hline Trama & $\begin{array}{l}\text { Enáulica 70\% } \\
\text { Porfírica 30\% }\end{array}$ & \begin{tabular}{|l|} 
Enáulica-85\% \\
Porfírica $15 \%$
\end{tabular} & $\begin{array}{l}\text { Enáulica-85\% } \\
\text { Porfírica } 15 \%\end{array}$ \\
\hline Feições & $\begin{array}{l}\text { Hiporevestimentos pequenos c/ } \\
\text { limite difuso, orientaçào } \\
\text { estriada, aderidos ao plasma }\end{array}$ & $\begin{array}{l}\text { Revestimentos zonados de poro, } \\
\text { orientação estriada, extinção } \\
\text { forte e contínua, nítido, aderidos } \\
\text { ao plasma. Porção superior da } \\
\text { lâmina }\end{array}$ & Cutãs. \\
\hline
\end{tabular}


PERFIL 5 - ARGISSOLO VERMELHO Distrófico latossólico

\begin{tabular}{|c|c|c|c|c|c|}
\hline Atrib./horiz. & BA (30-40) & Bt1 $(70-80)$ & Bt2 (130-140) & Bt3 (170-180) & Bw (210-220) \\
\hline $\begin{array}{c}\text { Micro- } \\
\text { estrutura }\end{array}$ & $\begin{array}{l}\text { Microagregados } \\
\text { intergra } \\
\text { nulares }(60 \%) \\
\text { ultra-finos e } \\
\text { blocos sub- } \\
\text { angulares (40\%) } \\
\text { de } 0,2 \text { a } 0,8 \mathrm{~mm} \text {, } \\
\text { e } 1,5 \mathrm{~mm}\end{array}$ & $\begin{array}{l}\text { Microagregados } \\
\text { intergra } \\
\text { nulares }(60 \%) \\
\text { ultra-finos e } \\
\text { blocos sub- } \\
\text { angulares }(40 \%) \\
\text { de } 0,2 \text { a1,0mm }\end{array}$ & $\begin{array}{l}\text { Microagregados } \\
\text { intergra } \\
\text { nulares }(70 \%) \\
\text { ultra-finos e } \\
\text { blocos sub- } \\
\text { angulares }(30 \%) \\
\text { de } 0,2 \text { a1,0mm }\end{array}$ & $\begin{array}{l}\text { Microagregados } \\
\text { intergra } \\
\text { nulares }(70 \%) \\
\text { ultra-finos e blo } \\
\text { cos sub-angulares } \\
(30 \%) \text { de } 0,2 \text { a } \\
1,5 \mathrm{~mm}\end{array}$ & $\begin{array}{l}\text { Microagregados } \\
\text { intergra } \\
\text { nulares (85\%) } \\
\text { ultra-finos e } \\
\text { blocos sub- } \\
\text { angulares (15\%) } \\
0,2 \text { a } 0,5 \mathrm{~mm}\end{array}$ \\
\hline $\begin{array}{c}\text { Plasmae } \\
\text { orientações } \\
\text { plásmicas }\end{array}$ & $\begin{array}{l}30 \% \\
\text { vermelho, } \\
\text { orientação } \\
\text { estriada } \\
\text { (granoestriada) e } \\
\text { manchada } \\
\text { (salpicada grânica } \\
\text { e em mosaico }\end{array}$ & $\begin{array}{l}30 \% \\
\text { vermelho, } \\
\text { orientação } \\
\text { estriada } \\
\text { (granoestriada) e } \\
\text { manchada } \\
\text { (salpicada grânica } \\
\text { e em mosaico } \\
\end{array}$ & \begin{tabular}{l|}
$25 \%$ \\
orientação \\
estriada \\
(granoestriada) e \\
manchada \\
(salpicada grânica \\
e em mosaico
\end{tabular} & \begin{tabular}{|l|}
$25 \%$ \\
vermelho, \\
orientação \\
estriada \\
(granoestriada) e \\
manchada \\
(salpicada grânica \\
e em mosaico \\
\end{tabular} & $\begin{array}{l}15 \% \\
\text { vermelho, } \\
\text { orientação } \\
\text { estriada } \\
\text { (granoestriada) e } \\
\text { manchada } \\
\text { (salpicada grânica } \\
\text { e em mosaico }\end{array}$ \\
\hline Esqueleto & $\begin{array}{l}50 \% \text {-de } 0,08 \text { a } \\
0,3 \mathrm{~mm}, \\
\text { predomínio de } \\
0,15 \mathrm{~mm} \text { (areia } \\
\text { fina), }\end{array}$ & $\begin{array}{l}50 \% \\
\text { de } 0,05 \text { a } 0,3 \mathrm{~mm} \\
\text { c/ predom/inio de } \\
0,15 \mathrm{~mm} \text { (areia } \\
\text { fina) }\end{array}$ & $\begin{array}{l}50 \% \\
\text { de } 0,05 \text { a } 0,3 \mathrm{~mm} \\
\text { c/ predom/inio de } \\
0,15 \mathrm{~mm} \text { (areia } \\
\text { fina) }\end{array}$ & $\begin{array}{l}45 \% \\
\text { de } 0,05 \text { a } 0,4 \mathrm{~mm} \\
\text { c/ predomínio de } \\
0,18 \mathrm{~mm} \text { (areia } \\
\text { fina) }\end{array}$ & $\begin{array}{l}50 \% \text { de } 0,05 \mathrm{a} \\
0,4 \mathrm{~mm} \mathrm{c} / \\
\text { predomínio de } \\
0,18 \mathrm{~mm} \text { (areia } \\
\text { fina }\end{array}$ \\
\hline Poros & $\begin{array}{l}20 \% \\
\text { Interagregada de } \\
\text { empilha mento } \\
(30 \%) \text {, cavitária } \\
(40 \%), 0,05 \text { a } 0,4 \\
\mathrm{~mm} \text {, canais }(10 \\
\%) 1 \mathrm{~mm} \text { e câma } \\
\text { ras (5\%)2mm } \\
\text { Intragregada } \\
\text { microporos } \\
\text { fissurais (10\%)e } \\
\text { meso poros cavi } \\
\text { tários (5\%) }\end{array}$ & $\begin{array}{l}20 \% \\
\text { interagregada de } \\
\text { empilha mento } \\
(30 \%) \text {, cavitária } \\
(40 \%)(0,05 \text { a } 0,2 \\
\mathrm{mm}, \text { canais } \\
(20 \%) \text { de } 1 \mathrm{~mm} \\
\text { Intragregada: } \\
\text { cavitária (5\%) e } \\
\text { fissural }(5 \%)\end{array}$ & $\begin{array}{l}25 \% \\
\text { interagregada de } \\
\text { empilha mento } \\
(50 \%) \text {, cavitária } \\
(25 \%)(0,06 \text { a } 0,2 \\
\mathrm{mm} \text {, canais } \\
(10 \%) \text { de } 0,6 \text { a } 1,5 \\
\mathrm{~mm} \\
\text { Intragregada: } \\
\text { cavitária }(10 \%) \text { e } \\
\text { fissural }(5 \%)\end{array}$ & $\begin{array}{l}25 \% \\
\text { Interagregada de } \\
\text { empilha mento } \\
(40 \%) \text { cavitária } \\
(30 \%) \text { (média } 0,4 \\
\mathrm{~mm}) \text { e canais } \\
(5 \%) \\
0,4 \text { a } 2,5 \mathrm{~mm} \\
\text { Intragregada } \\
\text { cavitária (10\%) e } \\
\text { fissural }(15 \%)\end{array}$ & $\begin{array}{l}35 \% \\
\text { Interagregada de } \\
\text { empilha mento } \\
(60 \%) \text {, cavitária } \\
(25 \%) \text { média de } \\
0,6 \mathrm{~mm} \text { e canais } \\
(5 \%) \text { (média de } \\
1 \mathrm{~mm}) \\
\text { Intragregada } \\
\text { cavitária }(5 \%) \\
\text { fissural }(5 \%)\end{array}$ \\
\hline Trama & $\begin{array}{l}\text { Enáulica }(60 \%) \\
\text { Porfírica }(40 \%)\end{array}$ & $\begin{array}{l}\text { Enáulica }(60 \%) \\
\text { Porfírica }(40 \%)\end{array}$ & $\begin{array}{l}\text { Enáulica (70\%) } \\
\text { Porfírica (30\%) }\end{array}$ & $\begin{array}{l}\text { Enáulica }(70 \%) \\
\text { Porfírica }(30 \%)\end{array}$ & $\begin{array}{l}\text { Enáulica (85\%) } \\
\text { Porfírica }(15 \%)\end{array}$ \\
\hline Feições & $\begin{array}{l}\text { Hiporevestimento, } \\
\text { revestimentos e } \\
(5 \%) \text { e ortotúbulos }\end{array}$ & $\begin{array}{l}\text { Hiporevestimento } \\
\mathrm{s} \quad(1 \%) \quad \mathrm{e} \\
\text { ortotúbulos }\end{array}$ & $\begin{array}{l}\text { Hiporevestimento } \\
\text { s, pápula e } \\
\text { ortotúbulos }\end{array}$ & $\begin{array}{l}\text { Revestimentos } \\
(1 \%) \text { e } \\
\text { ortotúbulos. }\end{array}$ & Ortotúbulos \\
\hline
\end{tabular}


PERFIL 6 - ARGISSOLO VERMELHO Distrófico abrúptico

\begin{tabular}{|c|c|c|c|c|}
\hline Atrib./horiz. & Bt2 (70-80) & Bt3 (120-130) & Bt4 (180-190) & $\operatorname{Btg}(220-230)$ \\
\hline $\begin{array}{c}\text { Micro- } \\
\text { estrutura }\end{array}$ & $\begin{array}{l}\text { Blocos suban } \\
\text { gulares }(60 \%) \text { 0,2 a 0,8 } \\
\text { mm } \\
\text { Microagregados } \\
\text { intergranulares (40\%) } \\
\text { c/ agregados } \\
\text { granulares ultra-finos }\end{array}$ & $\begin{array}{l}\text { Microagregados } \\
\text { intergra } \\
\text { nulares }(70 \%) \text { ultra- } \\
\text { finos e } \\
\text { blocos sub-angulares } \\
(30 \%)(0,2 \text { a1,0mm })\end{array}$ & $\begin{array}{l}\text { Microagregados } \\
\text { intergra } \\
\text { nulares }(70 \%) \text { ultra- } \\
\text { finos } \\
\text { Blocos sub-angulares } \\
(30 \%)(0,2 \text { a } 0,5 \mathrm{~mm} \text { e } \\
1,0 \mathrm{~mm})\end{array}$ & $\begin{array}{l}\text { Microagregados } \\
\text { intergranulares (70\%) } \\
\text { ultrafinos e } \\
\text { blocos sub-angulares } \\
(30 \%) 0,2 \text { a } 0,5 \mathrm{~mm} \mathrm{e} \\
1,0 \mathrm{~mm}\end{array}$ \\
\hline Plasma & $\begin{array}{l}40 \% \\
\text { Vermelho, argila e } \\
\text { óxidos de Fe } \\
\text { orientação estriada } \\
\text { (granoestriada) e } \\
\text { manchada (salpicada } \\
\text { grânica e em mosaico }\end{array}$ & $\begin{array}{l}35 \% \\
\text { vermelho, orientação } \\
\text { estriada } \\
\text { (granoestriada) e } \\
\text { manchada (salpicada } \\
\text { grânica e em mosaico }\end{array}$ & $\begin{array}{l}35 \% \\
\text { Vermelho, orientação } \\
\text { estriada } \\
\text { (granoestriada) e } \\
\text { manchada (salpicada } \\
\text { grânica e em mosaico }\end{array}$ & $\begin{array}{l}30 \% \\
\text { Vermelho, orientação } \\
\text { estriada } \\
\text { (granoestriada) e } \\
\text { manchada (salpicada } \\
\text { grânica e em mosaico }\end{array}$ \\
\hline Esqueleto & $\begin{array}{l}40 \% \\
\text { De } 0,08 \text { a } 0,3 \mathrm{~mm}, \\
\text { predomínio de } 0,15 \\
\mathrm{~mm} \text { (areia fina }\end{array}$ & $\begin{array}{l}45 \% \\
\text { De } 0,05 \text { a } 0,3 \mathrm{~mm} \mathrm{c} / \\
\text { predom/inio de } 0,15 \\
\mathrm{~mm} \text { (areia fina) }\end{array}$ & $\begin{array}{l}45 \% \\
\text { De } 0,05 \text { a } 0,4 \mathrm{~mm} \mathrm{c/} \\
\text { predomínio de } 0,18 \\
\mathrm{~mm} \text { (areia fina) }\end{array}$ & $\begin{array}{l}40 \% \\
\text { De } 0,05 \text { a } 0,4 \mathrm{~mm} \mathrm{c} / \\
\text { predomínio de } 0,18 \\
\text { mm (areia fina) }\end{array}$ \\
\hline Poros & $\begin{array}{l}20 \% \\
\text { Interagregada de } \\
\text { empilha mento }(10 \%), \\
\text { cavitária }(20 \%)(0,2 \mathrm{a} \\
0,4 \mathrm{~mm}) \\
\text { Intragregada fissurais } \\
(10 \%) \text { e cavitários } \\
(60 \%) \text { o,05 a } 0,3 \mathrm{~mm}\end{array}$ & $\begin{array}{l}30 \% \text { interagregada } \\
\text { empilhamento }(50 \%) \text {, } \\
\text { cavitária }(30 \%) 0,2 \mathrm{a} \\
0,6 \mathrm{~mm} \text { e canais } \\
(10 \%) 0,5 \mathrm{a} 2,5 \mathrm{~mm} \\
\text { Intragregada cavitária } \\
(8 \%) \\
\text { fissural }(2 \%)\end{array}$ & $\begin{array}{l}30 \% \\
\text { Interagregada } \\
\text { empilhamento }(30 \%) \text {, } \\
\text { cavitária }(50 \%)(0,1 \mathrm{a} \\
0,4 \mathrm{~mm}) \text { e canais }(5 \%) \\
\text { (i a } 2 \mathrm{~mm}) \\
\text { Intragregada } \\
\text { mesoporosidade } \\
\text { cavitária }(5 \%)(\sim 0,01 \\
\text { mm) e fissural }(10 . \%)\end{array}$ & $\begin{array}{l}30 \% \\
\text { Interagregada } \\
\text { Macroporosidade de } \\
\text { empilhamento }(30 \%), \\
\text { cavitária }(45 \%)(0,1 \mathrm{a} \\
0,4 \mathrm{~mm}) \mathrm{e} \text { canais } \\
(10 \%)(1 \text { a } 2,5 \mathrm{~mm}) \\
\text { Intragregada } \\
\text { mesoporosidade } \\
\text { cavitária } \\
(10 \%)(0,01 \mathrm{~mm}) \text { e } \\
\text { microporosidade } \\
\text { fissural }(5 \%)\end{array}$ \\
\hline Trama & $\begin{array}{l}\text { Porfírica (60\%) } \\
\text { Enáulica }(40 \%)\end{array}$ & $\begin{array}{l}\text { Enáulica }(70 \%) \\
\text { Porfírica }(30 \%)\end{array}$ & $\begin{array}{l}\text { Enáulica }(70 \%) \\
\text { Porfírica }(30 \%)\end{array}$ & $\begin{array}{l}\text { Enáulica }(70 \%) \\
\text { Porfírica }(30 \%)\end{array}$ \\
\hline Feições & $\begin{array}{l}\text { Hiporevestimentos } \\
(1 \%) \text { nos blocos } \\
\text { subangulares, } \\
\text { vermelhos, c/ extinção } \\
\text { forte e ortotúbulos e } \\
\text { revestimentos típicos } \\
\text { de argila. }\end{array}$ & $\begin{array}{l}\text { Ortotúbulos e nódulos } \\
\text { isóticos }(1 \%)\end{array}$ & & $\begin{array}{l}\text { Hiporevestimento nos } \\
\text { blocos subangulares e } \\
\text { teriam se formado em } \\
\text { fase anterior ao } \\
\text { desagregamento dos } \\
\text { mesmos }\end{array}$ \\
\hline
\end{tabular}

